UNIVERSIDADE DE SÃO PAULO

ESCOLA DE ENGENHARIA DE SÃO CARLOS

ROGÉRIO AKIHIDE IKEGAMI

Desenvolvimento de corpos cerâmicos compostos bioativos com estrutura de gradiente funcional

São Carlos 

ROGÉRIO AKIHIDE IKEGAMI

\section{DESENVOLVIMENTO DE CORPOS CERÂMICOS COMPOSTOS BIOATIVOS COM ESTRUTURA DE GRADIENTE FUNCIONAL}

Tese apresentada à Escola de Engenharia de São Carlos, da Universidade de São Paulo, para a obtenção do título de doutor em Engenharia Mecânica.

Área de concentração: Projeto Mecânico ORIENTADOR: Prof. Tit. Benedito de Moraes Purquerio

São Carlos 


\section{AUTORIZO A REPRODUÇÃO E DIVULGAÇÃO TOTAL OU PARCIAL DESTE TRABALHO, POR QUALQUER MEIO CONVENCIONAL OU ELETRÔNICO, PARA FINS DE ESTUDO E PESQUISA, DESDE QUE CITADA A FONTE.}

Ficha catalográfica preparada pela Seção de Tratamento da Informação do Serviço de Biblioteca - EESC/USP

Ikegami, Rogério Akihide

I26d Desenvolvimento de corpos cerâmicos compostos bioativos com estrutura de gradiente funcional / Rogério Akihide Ikegami ; orientador Benedito de Moraes Purquerio. -- São Carlos, 2007.

Tese (Doutorado-Programa de Pós-Graduação em Engenharia Mecânica. Área de Concentração: Projeto Mecânico) -- Escola de Engenharia de São Carlos da Universidade de São Paulo, 2007.

1. Compósitos cerâmicos. 2. Gradiente funcional. 3. Alumina. 4. Hidroxiapatita. 5. Biovidro. I. Título. 
Candidato: Engenheiro ROGERIO AKIHIDE IKEG_AM

Tese defendida e julgada em 10/07/2007 perante a Comissẩo Julgadora:

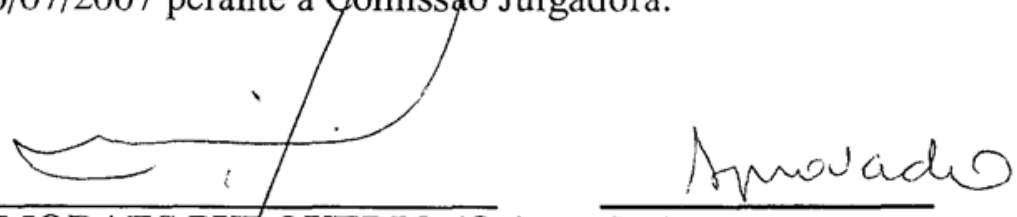

Prof. Titular BENEDITO DE MORAES PURQUERIO (Orientador)

(Escola de Engenharia de-§ão Carlos/USP)

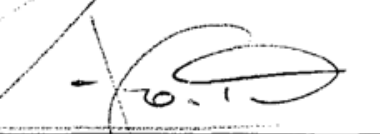

Prof. Dr. CARLÓS ALBERTO FORTULAN

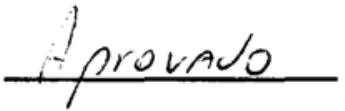

(Escola de Engenharia de São Carlos/USP)

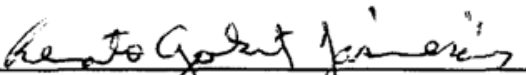

APRONADO

Prof. Associado RENATO GOULART JASINEVICIUS

(Escola de Engenharia de São Carlos/USP)

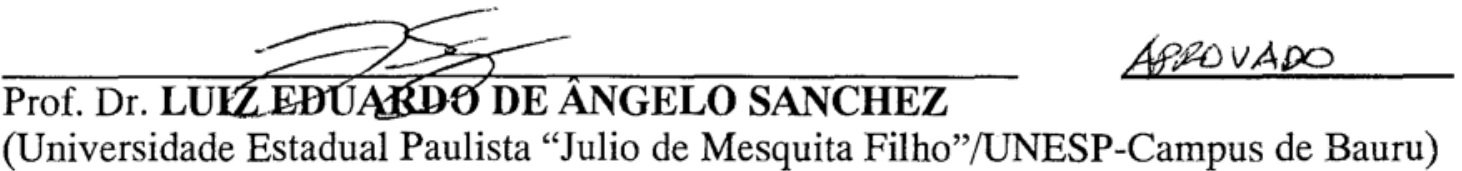

(Universidade Estadual Paulista "Julio de Mesquita Filho"/UNESP-Campus de Bauru)

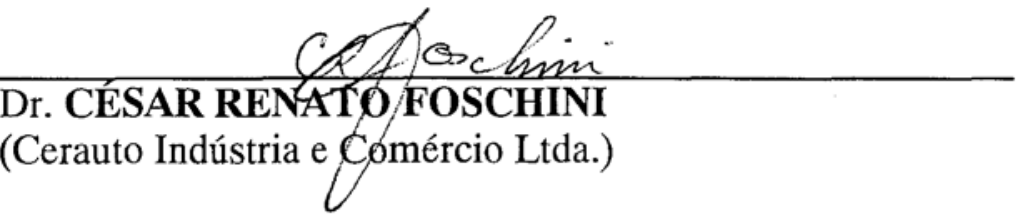

APROVADO

Dr. CESAR RENATO FOSCHINI

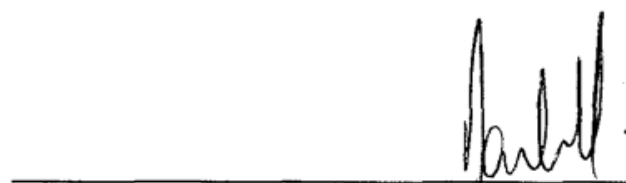

Prof. Associado JØNAS DE CARVALHO

Coordenador do Programa de Pós-Graduação em Engenharia Mecânica

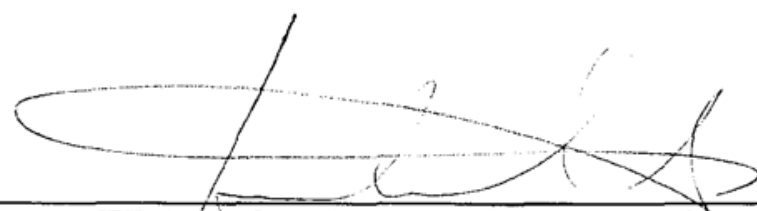

Prof. Associado GERALDO ROBERTO MARTINS DA COSTA

Presidente da Comissão da Pós-Graduação da EESC 

Aos meus pais Hiroshige e Yoshie pelos ensinamentos, dedicação e paciência.

À minha esposa Lígia, companheira, amiga e mãe dedicada, pela paciência e privações.

Ao meu filho Hiroaki pela alegria que me proporciona.

Muito obrigado a todos vocês! 



\section{AGRADECIMENTOS}

Ao Prof. Tit. Benedito de Moraes Purquerio, pela orientação, paciência, confiança, incentivo e profissionalismo.

Ao amigo e Prof. Dr. Carlos Alberto Fortulan pelo apoio e ensinamento.

Ao amigo e irmão Romeu Rony Cavalcante da Costa pelo incentivo, ajuda, cobrança e paciência.

À amiga Cláudia Cristiane Camilo e ao amigo Francisco Henrique Monaretti pela parceria, amizade e companheirismo nas atividades experimentais e no dia a dia.

Aos amigos de laboratório Rodrigo Canto, Amauri Bravo Ferneda, Volnei Tita, Geraldo Dantas, Thais Samed, Maria Alejandra e Cassius Riul pelos momentos alegres de descontração e auxílio.

Aos técnicos do LAMAFE Zé Carlos, Adão e Botelho pela amizade e prestação.

Ao Departamento de Materiais - EESC - USP e DEMA - UFSCar pelos ensaios mecânicos

À UTFPR (antigo CEFETPR) - Unidade de Cornélio Procópio pela liberação.

À CAPES pelo auxílio financeiro.

A todos os Professores, Funcionários e alunos do Departamento de Engenharia Mecânica pela excelente convivência. 



\section{RESUMO}

IKEGAMI, R. A. (2007). Desenvolvimento de Corpos Cerâmicos Compostos Bioativos com Estrutura de Gradiente Funcional. São Carlos, 2007. 110p. Tese (Doutorado) Escola de Engenharia de São Carlos, Universidade de São Paulo.

Este trabalho apresenta o desenvolvimento de corpos cerâmicos compostos bioativos com estrutura de gradiente funcional destinado à fabricação de componentes de implantes médicos. Na obtenção do compósito utilizou-se a alumina $\left(\mathrm{Al}_{2} \mathrm{O}_{3}\right)$ como base, a hidroxiapatita (HA) e o biovidro como componentes bioativos e a sacarose na obtenção da porosidade desejada. No desenvolvimento e na manufatura do material os métodos de processamento e os materiais utilizados foram selecionados de forma a atender as características desejadas para os componentes de implantes, ou seja, precisão dimensional, confiabilidade mecânica, desempenho em serviço, repetibilidade e custo aceitável. Como resultado, obteve-se um material estrutural com gradiente funcional de dupla camada. A dupla camada é composta de uma camada densa que confere a resistência mecânica desejada ao componente e a camada porosa promove a interação com os tecidos biológicos. A interação foi obtida com a infiltração de hidroxiapatita e biovidro na camada porosa. Ensaios mecânicos foram realizados para verificar a influência dos poros, da hidroxiapatita e do biovidro sobre a resistência mecânica do compósito. Foram executadas análises por microscopia eletrônica de varredura (MEV) e espectrometria de energia dispersiva de raios-X (EDS) para observação da estrutura porosa, morfologia, distribuição e comunicação dos poros, e a eficiência da infiltração da hidroxiapatita e do biovidro.

Palavras-chave: compósitos cerâmicos, gradiente funcional, alumina, hidroxiapatita, biovidro. 



\section{ABSTRACT}

IKEGAMI, R. A. (2007). Development of Bioactive Composite Ceramic Body with Functional Gradient Structure. São Carlos, 2007. 110p. Doctor Degree Thesis- Escola de Engenharia de São Carlos, Universidade de São Paulo.

This work shows the development of bioactive composite ceramic body with functional gradient structure to use in medical implant components. The used materials were, alumina $\left(\mathrm{Al}_{2} \mathrm{O}_{3}\right)$ as a base material, hydroxyapatite $(\mathrm{HA})$ and bioglass that were the bioactive components and sucrose used for obtaining pores. In the development and manufacture of the bioactive composite, the processing method and the materials were selected so that the dimensional characteristics, performance and repetition of production of the pieces present to the components specified characteristics with reliability and acceptable cost. The developed structure possesses a dense layer, which gives the mechanical resistance and a porous layer to have a biological interaction between the component and the tissue. Hydroxyapatite and bioglass were added in the porous layer to improve that interaction and mechanical tests were made in order to check if the pores, hydroxyapatite and bioglass, interferes the mechanical resistance of the components. Scanning Eletronic Microscopy (SEM) and Energy Dispersive X-ray (EDX) analysis were made to observe the porous structure and performance of the filtration of hidroxyapatite and bioglass.

Key-words: ceramic composite, functional gradient, alumina, hydroxyapatite, bioglass. 



\section{LISTA DE FIGURAS}

Figura 2.1 - Estrutura porosa de uma estrela do mar (rede fibrosa e desordenada)........... 42

Figura 2.2 - Escafolde de um osso bovino (poros esféricos e conectados). ...................... 44

Figura 2.3 - Características do MGF. Fonte (KOIZUMI, 1996) ..................................... 47

Figura 2.4 - Interface entre o osso compacto e esponjoso................................................ 48

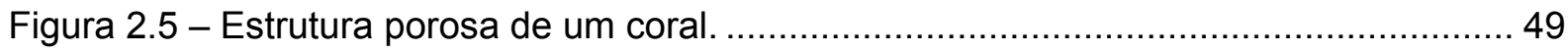

Figura 2.6 - Exemplos de corpos-de-prova de escafolde para ensaios mecânicos: (a) ensaio de compressão e (b) ensaio de tração. Fonte: (HOLLISTER et al, 2005)...................... 51

Figura 2.7 - Esquema da prensagem isostática. ................................................... 52

Figura 2.8 - Modelo de ensaio de flexão: (a) três pontos, (b) quatro pontos. Fonte: [ASTM

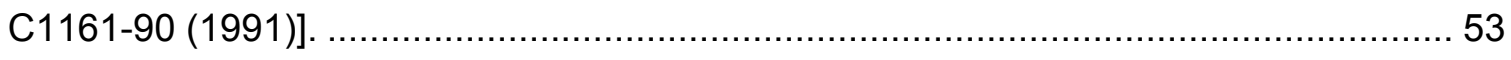

Figura 2.9 - Modelo de ensaio de compressão com a inserção de assentos. Fonte: Fortulan [1997, Apud Awaji; Nagano (1993)]. 54

Figura 2.10 - Distribuição típica de Weibull. Fonte: RICHERSON (apud FORTULAN, 1997) 56

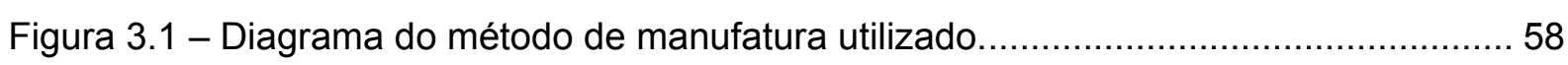

Figura 3.2 - Diagrama de fluxo da metodologia utilizada......................................... 59

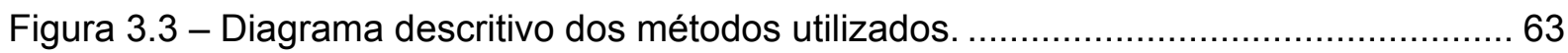

Figura 3.4 - Molde para confecção de barras para ensaio de flexão ................................... 66

Figura 3.5 - Molde para conformação de pastilhas e corpos-de-prova para compressão.... 67

Figura 3.6 - Escafoldes conformados em formato de pastilha...................................... 67

Figura 3.7 - Escafoldes conformados para ensaio de compressão................................ 68

Figura 3.8 - Corpo-de-prova (escafolde) de hidroxiapatita para compressão. ................... 72

Figura 3.9 - Ensaio de compressão de escafolde de hidroxiapatita. ................................ 72

Figura 3.10 - Corpos-de-prova para ensaio de flexão. ….......................................... 73

Figura 3.11 - Ensaio de flexão em três pontos. ..................................................... 73 
Figura 3.12 - Moldes utilizados para a confecção de implantes dentários por colagem de barbotina. 74

Figura 3.13 - a) Barras prensadas isostaticamente; b) Barra fixada num dispositivo para usinagem. 75

Figura 3.14 - a) Visão geral da máquina; b) detalhe da usinagem da barra. 75

Figura 4.1 - ATG do naftaleno. .78

Figura 4.2 - ATG da sacarose. 78

Figura 4.3 - ATG do PVB 79

Figura 4.4 - Curva de aquecimento do forno para sinterização dos escafoldes. 80

Figura 4.5 - Barras para ensaio de flexão. 80

Figura 4.6 - Destacamento da camada porosa. 81

Figura 4.7 - Falha na camada porosa. 82

Figura 4.8 - Distribuição de Weilbull, a) corpos densos, b) corpos porosos e c) bicamada.. 85

Figura 4.9 - Cilindro de escafolde para ensaio de compressão. 86

Figura 4.10 - Corpo-de-prova submetido a ensaio de compressão. 86

Figura 4.11 - Gráfico do ensaio de compressão dos escafoldes de alumina. 87

Figura 4.12 - Gráfico do ensaio de compressão dos escafoldes de hidroxiapatita. 87

Figura 4.13 - Gráfico do ensaio de compressão dos escafoldes de alumina impregnada. .. 88

Figura 4.14 - Transição da camada densa com a porosa. 89

Figura 4.15 - Interface cortada e polida do corpo-de-prova. 90

Figura 4.16 - Interface impregnada com resina, cortada e polida. 90

Figura 4.17 - Camada porosa formada por sacarose. 91

Figura 4.18 - Interface cortada e polida de corpo-de-prova poroso. 91

Figura 4.19 - EDX da alumina (AI2O3) infiltrada com hidroxiapatita-biovidro. 92

Figura 4.20 - O mapeamento de EDX nas amostras de alumina infiltrada por biovidro/hidroxiapatita. .93

Figura 4.21 - Implante dentário com camada porosa. 94

Figura 4.22 - Implante dentário sem camada porosa. 94 


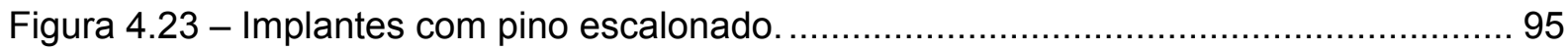

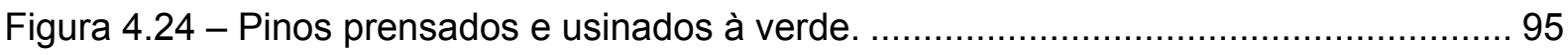

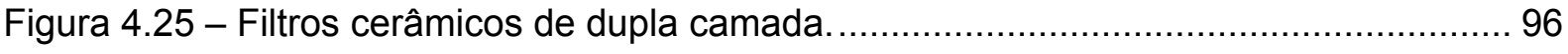

Figura 4.26 - MEV do filtro cerâmico de dupla camada com ampliação de $27 X$................ 96

Figura 4.27 - MEV do filtro cerâmico de dupla camada com ampliação de 200X ............... 97

Figura 4.28 - MEV do filtro cerâmico de dupla camada com ampliação de 2000X ............. 97 



\section{LISTA DE TABELA}

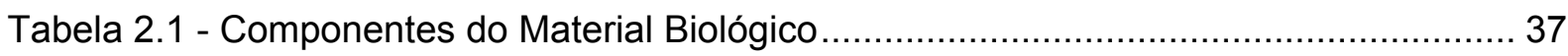

Tabela 2.2 - Aplicação dos Biomateriais Sintéticos. ................................................... 38

Tabela 2.3 - Classificação de biocerâmicas (HENCH,1993)........................................... 41

Tabela 3.1 - Custo dos materiais utilizados para manufatura dos escafoldes (Camilo, 2006).

60

Tabela 3.2 - Máximo de impurezas da sacarose (Camilo, 2006) ...................................... 62

Tabela 4.1 - Retração Linear dos corpos de prova sinterizados em \%. ............................ 81

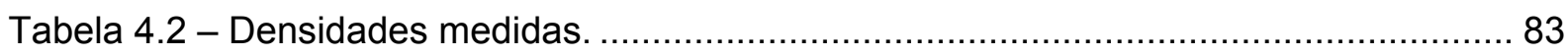

Tabela 4.3- Valores da média e desvio padrão do ensaio de compressão. ......................... 88 



\section{LISTA DE ABREVIATURAS E SIGLAS}

ASTM

ATG

CAQI

CBA

DCC

DEMA

EDS

EDX

EESC

ET

GCCMC

HA

HAS

HDPE

IFSC

IQSC

LASP

MEV

MGF

$\mathrm{MPa}$

NETeF

NSF

PVB

UFSCar

USP
American Society for Testing and Materials

Análise Termogravimétrica

Central de Análises Químicas Instrumentais

Cerâmica Bioativa

Consolidação por Coagulação Direta

Departamento de Materiais

Espectrometria de Energia Dispersiva de Raios-X

Energy Dispersive X-ray

Escola de Engenharia de São Carlos

Engenharia de Tecidos

Grupo de Crescimento de Cristais e Materiais Cerâmicos

Hidroxiapatita

Solidificação Assistida por Hidrólise

Polietileno de Alto Peso Molecular

Instituto de Física de São Carlos

Instituto de Química de São Carlos

Laboratório de Síntese e Processamento de Materiais Cerâmicos

Microscopia Eletrônica de Varredura

Material com Gradiente Funcional

Mega Pascal

Núcleo de Engenharia Térmica e Fluídos

National Science Fundation

Polivinil Butirol

Universidade Federal de São Carlos

Universidade de São Paulo 


\section{LISTA DE SIMBOLOS}

\begin{tabular}{|c|c|}
\hline $\mathrm{Al}_{2} \mathrm{O}_{3}$ & Alumina \\
\hline $\mathrm{Ca}_{3}\left(\mathrm{PO}_{4}\right)_{2}$ & Fosfato Tricálcio \\
\hline $\mathrm{Ca}_{10}\left(\mathrm{PO}_{4}\right)_{6}(\mathrm{OH})_{2}$ & Hidroxiapatita \\
\hline $\mathrm{Cd}$ & Cádmio \\
\hline $\mathrm{Cl}$ & Cloro \\
\hline Co & Cobalto \\
\hline $\mathrm{Cu}$ & Cobre \\
\hline$D_{a p}$ & Densidade Aparente \\
\hline$E$ & Módulo de Elasticidade \\
\hline $\mathrm{Fe}$ & Ferro \\
\hline $\mathrm{GPa}$ & Giga Pascal \\
\hline $\mathrm{h}$ & altura \\
\hline K & Potássio \\
\hline $\mathrm{MPa}$ & Mega Pascal \\
\hline $\mathrm{Na}$ & Sódio \\
\hline $\mathrm{Ni}$ & Níquel \\
\hline$P_{\text {ap }}$ & Porosidade Aparente \\
\hline $\mathrm{Pb}$ & Chumbo \\
\hline$P_{i}$ & Peso Imerso \\
\hline$P_{s}$ & Peso Seco \\
\hline$P_{u}$ & Peso Úmido \\
\hline$P_{\text {total }}$ & Porosidade Total \\
\hline $\mathrm{SO}_{4}$ & Sulfato \\
\hline $\mathrm{Na}_{2} \mathrm{O}-\mathrm{CaO}-\mathrm{CaF}_{2}-\mathrm{P}_{2} \mathrm{O}_{5}-\mathrm{SiO}_{2}$ & Biovidro \\
\hline $\mathrm{Ti}$ & Titânio \\
\hline $\mathrm{TiO}_{2}$ & Dióxido de Titânio \\
\hline
\end{tabular}


$\mathrm{Zn}$

$\mathrm{ZrO}_{2}$

$\propto-\mathrm{Al}_{2} \mathrm{O}_{3}$

$\phi$

$\mu \mathrm{m}$

$\rho$

$\rho_{\text {th }}$

$\sigma$
Zinco

Zircônia

Alumina densa

Diâmetro

Micrômetro

Densidade Real

Densidade Teórica

Tensão 


\section{SUMÁRIO}

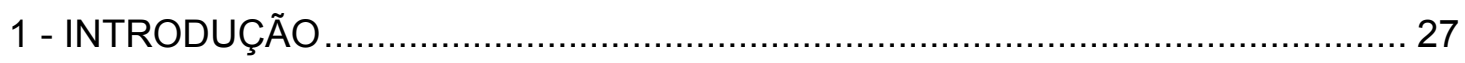

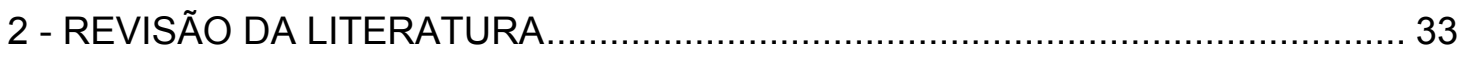

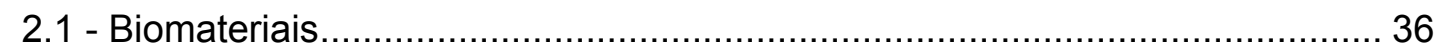

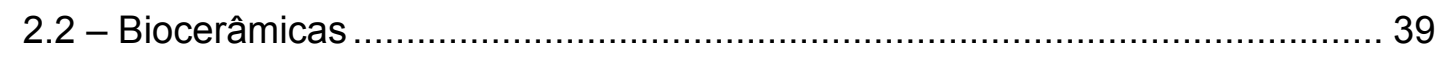

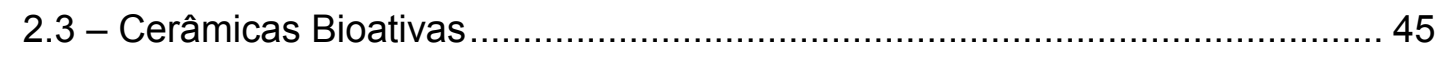

2.4 - Materiais com Gradiente Funcional (MGF) ........................................ 46

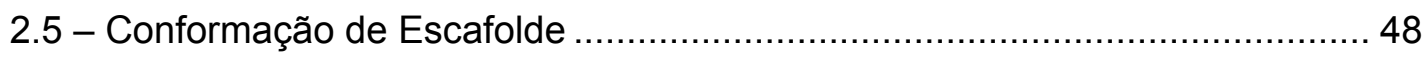

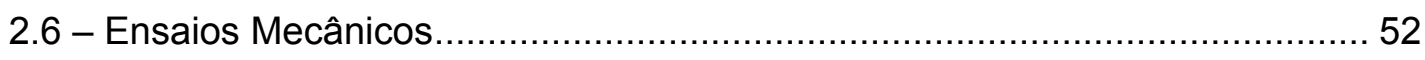

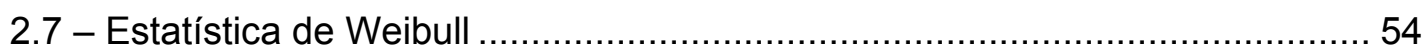

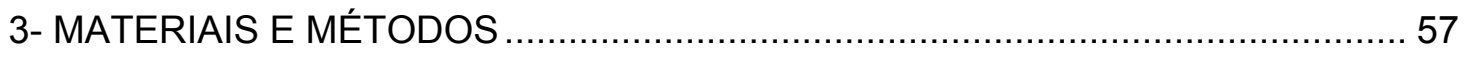

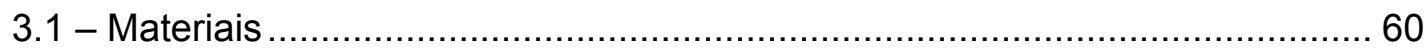

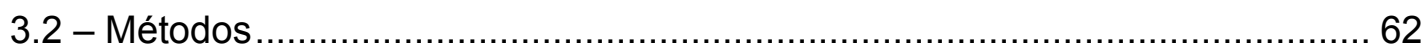

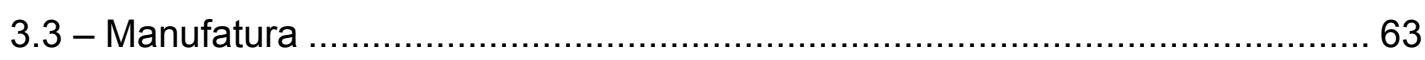

3.3.1 - Preparação da Suspensão ou Barbotina ....................................... 64

3.3.2 - Moagem e classificação dos agentes porogênicos .............................6 65

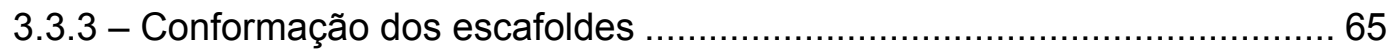

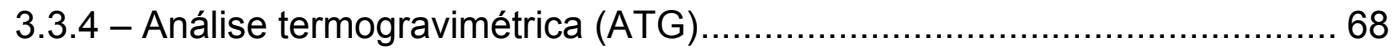

3.3.5 - Programação do forno de sinterização ............................................ 69

3.3.6 - Infiltração da barbotina biovidro/hidroxiapatita ................................ 69

3.3.7 - Análise macro e microestrutural dos escafoldes ...............................6 69

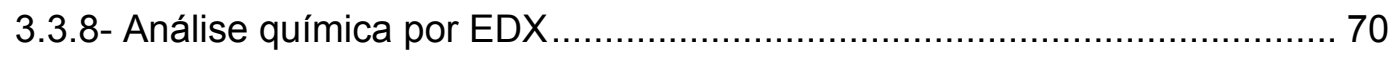

3.3.9- Análise da densidade e porosidade aparente dos escafoldes ................ 70

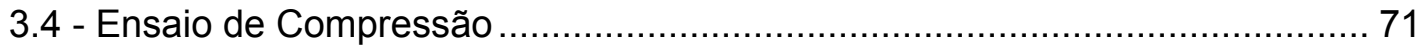

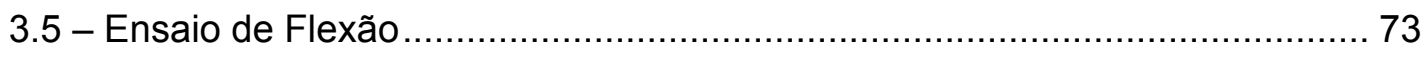

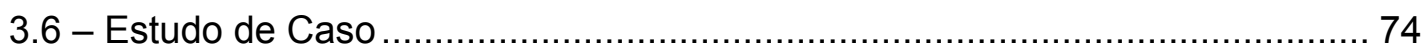




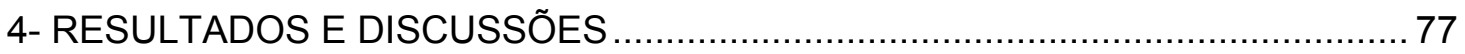

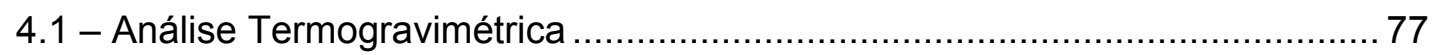

4.2 - Programação do Forno para Sinterização...................................................... 79

4.3 - Manufatura das Barras para Ensaio de Flexão …..................................... 80

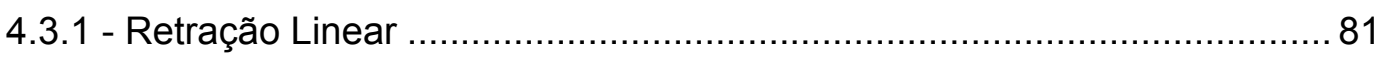

4.3.2 - Densidade aparente (Dap ), porosidade aparente (Pap) ...................... 83

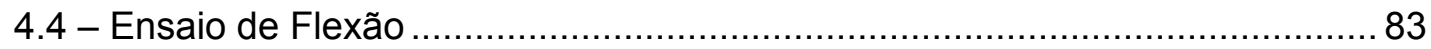

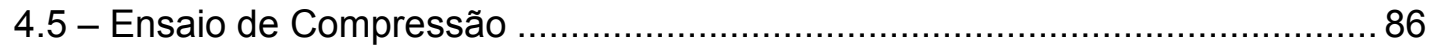

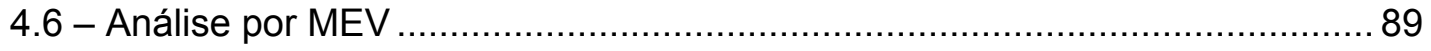

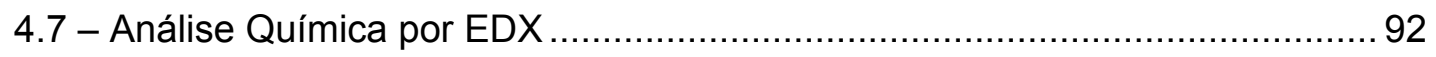

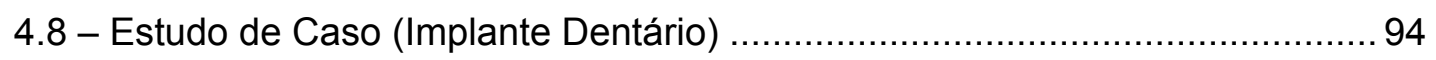

4.9 - Estudo de Caso (Filtro Cerâmico de Dupla Camada)................................... 96

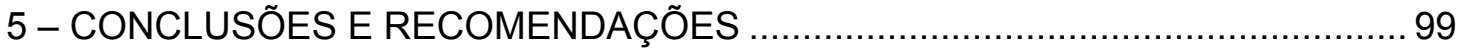

5.1 - Recomendações para Trabalhos Futuros ............................................... 100

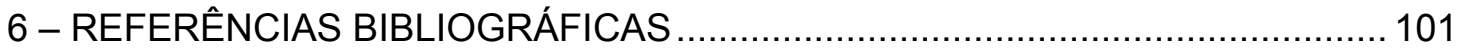




\section{1 - INTRODUÇÃO}

Ao longo dos anos, a vida humana vem sendo alterada em direção à busca pelo aumento da longevidade. A procura por uma qualidade de vida superior, a preocupação com a alimentação, os avanços tecnológicos na medicina e o aperfeiçoamento nos métodos de diagnóstico têm proporcionado a diminuição no período de recuperação e um aumento no número de pessoas idosas e, conseqüentemente, de doenças relacionadas. Entre essas doenças existem as relativas à estrutura óssea, como por exemplo, a osteoporose, a osteoartrose e a perda de massa óssea que afetam diretamente na qualidade de vida das pessoas. Além destas doenças, a ocorrência de traumas nos tecidos ósseos devido a acidentes (automobilístico e trabalho) e a falta de cuidado ou higiene (por exemplo, perda dos dentes) atingem indivíduos jovens em sua fase mais produtiva (KAWACHI, et al, 2000).

A substituição dos tecidos ósseos em decorrência de patologias e traumatologias ortopédicas ou odontológicas tem incentivado pesquisas em busca de materiais para substituições ósseas e dentárias. No passado, quando não havia recursos para restaurar ou substituir danos no tecido ósseo, os membros ou partes eram amputados. Em meados do século XVII, FALLOPIUS (1600) implantou uma placa de ouro para restaurar um defeito craniano. Desde então, têm sido utilizados enxertos e implantes para a substituição de 
partes ósseas danificadas, com a utilização de técnicas de enxertos ósseos e de vários tipos de materiais [MONARETTI (a), 2005].

Durante o século passado, materiais sintéticos e dispositivos foram desenvolvidos para repor ou restaurar com sucesso as funções dos tecidos doentes ou danificados. No campo da ortopedia, o uso de implantes metálicos ocasionou uma significativa melhora da qualidade de vida. Fatores críticos para o sucesso de um implante incluem um projeto adequado, a correta seleção dos materiais e a biocompatibilidade (CAMPBELL, 2003).

A utilização de implantes e enxertos tem aumentado significativamente nos últimos anos, principalmente devido ao aumento da vida média da população e ao elevado índice de acidentes automobilísticos. O mercado nacional de implantes ortopédicos está estimado em US\$ 64 milhões anuais. No mundo, este índice alcançou o montante de US\$ 4,4 bilhões em 1999. São realizados, em média, 24 mil implantes de prótese total de quadril por ano no Brasil (IPEN, 2005).

Pesquisas em diversas áreas estão sendo realizadas visando a solução desses problemas. Numa dessas áreas, a Engenharia de Tecidos (ET) objetiva a obtenção de materiais destinados à substituição e ao preenchimento de tecidos ósseos ou à reposição dentária. Dentre os materiais pesquisados, as cerâmicas são de fundamental importância por serem praticamente bioinertes ou bioativas, permitindo a fabricação de componentes com estrutura densa ou porosa. Há muitos anos observa-se um crescente interesse no desenvolvimento e na aplicação de corpos cerâmicos porosos com microestrutura controlada e estabilidade mecânica [MONARETTI (a), 2005].

As cerâmicas porosas podem apresentar certas propriedades, como baixa densidade, baixa condutividade térmica, alta área superficial e alta permeabilidade, associada às características inerentes aos materiais cerâmicos como alta refratariedade e resistência a ataques químicos. Tais características possibilitam o uso desses materiais em aplicações tecnológicas como filtragem em altas temperaturas, suportes para catálise, isolamento térmico, implantes ósseos, entre outras. A introdução de poros nos materiais cerâmicos ocasiona, entretanto, a redução da resistência mecânica e dos módulos elásticos. 
Além disso, a maioria dos processos de fabricação de cerâmicas porosas proporciona corpos com grande quantidade de trincas e macrodefeitos, provocando a deterioração das propriedades mecânicas (ORTEGA, 2003).

Inúmeros processos são atualmente utilizados na produção de cerâmicas porosas. As técnicas mais simples baseiam-se na incorporação de uma segunda fase orgânica na composição do material cerâmico, em proporções e tamanhos controlados, que após a eliminação deixam vazios de mesmo tamanho (SEPÚLVEDA, 1999).

No desenvolvimento e na manufatura de componentes cerâmicos, o método de processamento e os materiais devem ser selecionados, sobretudo relativamente às características dimensionais, desempenho e quantidades necessárias, bem como na capacidade do processo de oferecer aos componentes, as características especificadas com confiabilidade e custo aceitável.

Entre as muitas etapas de processamento, a seleção e o refinamento da tecnologia de conformação exercem grande influência sobre as características desejadas. Defeitos ou embriões de defeitos que acompanham a vida de um componente são introduzidos na conformação.

É conhecido que a vida de um componente cerâmico, sob alto estado de tensão mecânico ou térmico, é determinada pela existência de defeitos que podem se apresentar na forma de vazios, inclusões, alguns grãos muito grandes, regiões com grande concentração de pequenos vazios ou com grãos mal densificados.

As cerâmicas porosas podem ser consideradas como materiais de baixa resistência mecânica, já que as inclusões podem ser consideradas como fontes potenciais de concentração de tensão. Para aplicações em membranas ou para a engenharia de tecidos os poros devem ser comunicantes para possibilitar o crescimento do tecido ósseo.

Os poros comunicantes e as potenciais inclusões acentuam ainda mais o estado de concentração de tensão. As cerâmicas porosas podem ser classificadas em quatro estruturas básicas: rede fibrosa desordenada, estrutura de poros abertos, estrutura de poros fechados, membranas ou ainda, a mistura deles (IKEGAMI, 2005). 
Existem diferentes técnicas para a obtenção desses materiais. Dentre eles estão: o método da esponja polimérica, "foaming" (utilização de um agente espumante), aditivos orgânicos fugitivos, entre outros. O problema crucial destas técnicas é como controlar o processamento e as propriedades finais em termos de estrutura porosa e dimensões do componente, já que na esponja polimérica, por exemplo, as propriedades mecânicas obtidas estão diretamente relacionadas à forma e à característica da esponja. Outros métodos de conformação, chamados de "Técnicas de Conformação Direta", baseiam-se na obtenção de corpos cerâmicos a partir de suspensão de pós (barbotinas) consolidadas em moldes impermeáveis. Alguns exemplos são: reação de polimerização (gel casting), destabilização (consolidação por coagulação direta, DCC), reação por policondensação (solidificação assistida por hidrólise, HAS), ou refrigeração (Quick Set). Uma das vantagens da utilização destas técnicas reside na obtenção de boa homogeneidade do material, que promove um bom controle da retração durante a fase de sinterização e assim possibilita obter as dimensões finais desejadas dos produtos. As desvantagens associam-se ao uso de agentes tóxicos na água, base do gel casting (ALMEIDA, 2005).

Materiais com gradiente funcional (MGF) são considerados como uma nova geração de materiais para engenharia, cuja principal característica é a possibilidade do mesmo componente exercer múltiplas funções, de acordo com as composições utilizadas. Para Ma e Tan (2001), os MGF's são a solução para várias aplicações avançadas onde dois ou mais materiais com propriedades distintas são exigidas para se tornarem um único material.

Os MGF's são uma nova classe de materiais compósitos, ao qual as fases constituintes não estão distribuídas uniformemente no espaço, mas dão origem a mudanças graduais na composição e microestrutura (CANNILLO, MANFREDINI et al 2006).

Os MGF's são materiais compostos avançados que são criados para que tenham uma variação espacial da propriedade do material. Isto é alcançado pela fabricação do material composto para que tenha uma gradual variação espacial do volume fracional relativo e microestrutura de seus componentes, cuja escolha é baseada nas exigências de desempenho funcional do material (GOUPEE, 2006). 
Estado de hipótese: projeto e conformação de um corpo cerâmico com estrutura de gradiente funcional que tenha sua camada externa bioativada para a osteointegração e a camada interna rígida de tal forma a suportar os esforços mecânicos.

Este trabalho trata com originalidade o projeto e manufatura de um corpo com MGF a qual é aplicado na obtenção de dois estudos de caso, são eles: prótese dentária e filtro cerâmico de dupla camada. O principal objetivo é reunir as propriedades mecânicas e a bioinércia da alumina e associá-las às propriedades bioativas da hidroxiapatita (HÁ) e do vidro bioativo no desenvolvimento de corpos cerâmicos compostos bioativos com estrutura de gradiente funcional. Na estrutura a alumina permite que o material resista à aplicação de cargas mecânicas, a HA possibilita a condução e ao crescimento ósseo e o vidro ativo funciona como indutor ósseo e retentor de HA. 


\section{2 - REVISÃO DA LITERATURA}

Engenharia de Tecidos (ET) é um dos campos mais recentes de desenvolvimento da engenharia de materiais que vem obtendo grandes progressos nas últimas duas décadas. $\mathrm{O}$ termo "Engenharia de Tecido" foi citado pela primeira vez numa reunião patrocinada pela NSF (National Science Fundation) em 1987 e num workshop a Engenharia de Tecido foi definida como "a aplicação dos princípios e métodos da engenharia e ciência da vida com respeito ao entendimento da relação estrutura-função da função normal e patológica" (Five Year Plan-MATES, 2006).

A ET é uma disciplina que envolve os princípios da biologia, biomateriais e engenharia e pode ser definida como sendo a ciência do projeto e manufatura de novos tecidos para restauração funcional dos órgãos e tecidos danificados ou perdidos numa doença ou trauma (REDDI, 1998). Para Sachlos e Czernuszka (2003), a ET é um campo multidisciplinar que envolve a "aplicação de princípios e métodos da engenharia e ciências biológicas para um entendimento da estrutura fundamental relacionado com os tecidos normais e patológicos dos mamíferos e o desenvolvimento de substitutos biológicos que restauram, mantém ou melhoram a função do tecido".

A escolha de um material para ser usado como biomaterial passa necessariamente pela análise de um conjunto de requisitos que devem ser encontrados. O efeito do ambiente orgânico no material (corrosão, degradação) e o efeito do material no organismo são 
fenômenos que devem ser estudados com extremo cuidado, pois a eles está associado a chamada "biocompatibilidade" (PEREIRA et al, 1999).

Os biomateriais são materiais utilizados na substituição de tecidos humanos e devem apresentar propriedades físicas e biológicas compatíveis com os tecidos vivos hospedeiros, de modo a estimular uma resposta adequada dos mesmos. Tais propriedades caracterizam a biocompatibilidade (WILLIAMS, 1987). Esses materiais são aplicados em dispositivo médico com intenção de interagir com sistemas biológicos. Os biomateriais são usados em Odontologia e em Medicina, sendo que, na ortopedia, vários tipos são utilizados para preenchimento e estabilização óssea (REYES, 2000).

Para implantes, os materiais precisam satisfazer todas as propriedades da biocompatibilidade, resistência mecânica e resistência à corrosão. O titânio (Ti) é um dos melhores metais biocompatíveis e um dos mais utilizados como implante. A HA, principal componente do osso e do dente, possui propriedades bioativas para formação de osso. 0 vidro também é um dos materiais para uso biomédico (WATARI et al, 2004).

Um componente chave na ET para a regeneração óssea é o scaffold, que será traduzido como escafolde e cujo significado é estrutura porosa, que serve como um caminho para a interação das células e formação de uma matriz óssea extracelular para fornecer suporte estrutural, para a formação de um novo tecido (KARAGEORGIOU, 2005).

O escafolde na ET é utilizado para facilitar o crescimento das células humanas e uma das principais motivações está na dificuldade da doação de órgãos e pelo longo tempo de administração de drogas para a prevenção da rejeição de órgãos implantados (BATCHELOR, 2004).

A porosidade, para materiais cerâmicos utilizados em implantes, surge como uma característica importante destes materiais. Apesar do aumento da porosidade diminuir a resistência mecânica do material isoladamente, a existência de poros com dimensões adequadas pode favorecer o crescimento do tecido através deles, fazendo com que ocorra um forte entrelaçamento do tecido com o implante, aumentando, por conseguinte, a resistência do material in vivo (KAWACHI, 2000). A alta área superficial permite maior área 
de contato entre o implante e o tecido hospedeiro, o que aumenta a resistência da interface e evita mobilidade do implante, diminuindo assim as chances de respostas inflamatórias. A HA é um fosfato cerâmico, ou biocerâmica, que tem composição e estrutura similares à fase mineral de ossos e dentes e são utilizadas no preenchimento de cavidades, na forma de grãos densos ou porosos, bem como no revestimento de implantes metálicos, estes geralmente feitos com o metal titânio. Neste último caso, procura-se melhorar as características dos implantes, combinando-se a resistência mecânica do metal à biocompatibilidade e à atividade biológica do material cerâmico (ROSSI et al, 2005). Cerâmicas porosas à base de HA possuem grande potencial de aplicação na área de implantes ósseos e isso se deve primeiramente à alta compatibilidade do material, cuja constituição química é similar à do osso.

Devido à similaridade química da HA com a fase mineral dos tecidos ósseos, ela é um dos materiais mais biocompatíveis conhecidos, favorecendo o crescimento ósseo para os locais em que ela se encontra (osteocondutor), estabelecendo ligações de natureza química entre ela e o tecido ósseo (bioativo), permitindo a proliferação de fibroblastos, osteoblastos e outras células ósseas, as quais não a distinguem da superfície óssea, o que indica a grande similaridade química superficial. A superfície da HA permite a interação de ligações do tipo dipolo, fazendo que moléculas de água e, também, proteína e colágeno sejam adsorvidos na superfície, induzindo assim, a regeneração tecidual (SANTOS, 2002).

A osseointegração é uma resposta biológica descoberta pelo suéco Per-Ingvar Brånemark na década de cinqüenta, através da qual um implante é sustentado exclusivamente pelo osso que se adaptou as novas condições, quando então recebe o nome de implante osseointegrado (GAZZIRO, 2004).

Os processos mais difundidos para a fabricação de corpos porosos cerâmicos são: adição de um componente degradável e volátil com a temperatura, uso de peróxido de hidrogênio em barbotina, gelcasting, método da esponja, fabricação em ambiente de microgravidade, produção de estrutura em cera perdida pela técnica de prototipagem rápida e prototipagem rápida pela técnica de impressão 3D (3D printing) [MONARETTI (a), 2005]. 
O escafolde, para implante, deve ter a resistência mecânica necessária para a retenção da sua estrutura após a sua implantação, particularmente na reconstrução de tecido duro e de pares tribológicos, como ossos e articulações. A bioestabilidade de muitos implantes depende de fatores como força aplicada, elasticidade do material, absorção na interface do material e degradação química. A repetibilidade do processo de fabricação do implante é de extrema importância devido a sua forma final ter uma influência crítica na sua função. E também para se manter a estabilidade dimensional do implante. $O$ corpo poroso cerâmico pode conter aditivos ou agentes ativos para o rápido crescimento do tecido ou para melhorar a compatibilidade. Por exemplo, um implante ósseo pode conter fosfato de cálcio ou um fator de crescimento como uma das proteínas morfogenéticas do osso (YANG, 2001).

\section{1 - Biomateriais}

A utilização de biomateriais data de antes das civilizações antigas. Olhos, orelhas, dentes e narizes artificiais foram encontrados nas múmias egípcias. Chineses e Indianos utilizaram ceras, colas e tecidos na reconstrução de partes perdidas ou defeituosas do corpo. Durante séculos, o avanço dos materiais sintéticos, técnicas cirúrgicas e métodos de esterilização têm possibilitado o uso de biomateriais. Hoje em dia, a prática médica utiliza um grande número de dispositivos e implantes. Biomateriais em forma de implantes (sutura, placas de fixação, implantes de quadril, ligamentos, enxertos vasculares, válvulas cardíacas, lentes intra-oculares, implantes dentários, etc.) e dispositivos médicos (marca passos, biosensores, coração artificial, tubos sanguíneos, etc.) são amplamente utilizados para repor e/ou restaurar a função do órgão ou tecido traumatizado ou degenerado, para ajudar na cura, melhorar a função, corrigir anomalias e assim melhorar a qualidade de vida do paciente (RAMAKRISHNA, 2001). 
A ciência dos biomateriais, segundo Ratner (1996), é o estudo da aplicação de materiais para a solução de problemas da biologia e medicina e é um campo caracterizado por necessidades médicas, pesquisa básica, desenvolvimento tecnológico avançado, considerações éticas, envolvimento industrial e regulamentação federal.

Para Ikada (2002), os biomateriais utilizados podem ser divididos em duas categorias: biológico e sintético. Os materiais biológicos são compostos por polipeptídios (proteínas), polissacarídeos, ácido nucléico, poliéster, HA ou suas composições. A Tabela 2.1 fornece a representatividade dos materiais biológicos. Para o ácido nucléico ainda não foi encontrada uma aplicação como biomaterial devido a sua baixa propriedade mecânica. Vantagens inigualáveis dos materiais biológicos sobre os sintéticos são as suas excelentes atividades fisiológicas como a adesão seletiva das células (por exemplo, colágeno e fibrina), similar propriedade mecânica com os tecidos naturais (por exemplo, válvula cardíaca animal e vaso sanguíneo) e a biodegradabilidade (por exemplo, gelatina e quitina). Entretanto, similar ao material sintético, materiais biológicos possuem muitas deficiências incluindo o risco de infecção viral, reação antigênica, suprimento instável de material e deterioração que acompanha o longo prazo de implantação. A biodegradabilidade do material biológico poderá ser vantajosa ou desvantajosa e depende da sua aplicação biomédica.

Tabela 2.1 - Componentes do Material Biológico

\begin{tabular}{|l|l|l|l|l|}
\hline \multicolumn{3}{|c|}{ Material orgânico } & \multicolumn{2}{c|}{ Material Inorgânico } \\
\hline \multicolumn{1}{|c|}{ polipeptídio } & polissacarídeo & \multicolumn{1}{|c|}{ poliéster } & \multicolumn{1}{c|}{ fosfatos } & \multicolumn{1}{c|}{ carbonatos } \\
\hline Colágeno & Celulose & Poli(2- & Hidroxiapatita & Carbonato de \\
Gelatina & Amido & hidroxibutirate $)$ & [Ca10(PO4)6(OH)2] & cálcio [CaCO3] \\
Fibrina & Dextran & (PHB) & Fosfato tricálcio & \\
Albumina & Quitina & & [Ca3(PO4)2] & \\
Seda de & Quitosana & & & \\
fibroina & Hyaluronate & & & \\
& Alginate & & & \\
& Agarose & & & \\
& & & & \\
\hline
\end{tabular}


Tabela 2.2 - Aplicação dos Biomateriais Sintéticos.

\begin{tabular}{|c|c|c|c|}
\hline BIOMATERIAL & VANTAGENS & DESVANTAGENS & APLICAÇÕES \\
\hline \multicolumn{4}{|l|}{ Polímeros } \\
\hline $\begin{array}{l}\text { Polietileno } \\
\text { PTFE } \\
\text { Poliéster } \\
\text { Poliuretano } \\
\text { PMMA } \\
\text { Silicona }\end{array}$ & $\begin{array}{l}\text { Elasticidade, fácil } \\
\text { fabricação, baixa } \\
\text { densidade }\end{array}$ & $\begin{array}{l}\text { Baixa resistência } \\
\text { mecânica, } \\
\text { degradação } \\
\text { dependente do } \\
\text { tempo }\end{array}$ & $\begin{array}{l}\text { Suturas, artérias, } \\
\text { veias; maxilofacial } \\
\text { (nariz, orelha, } \\
\text { maxilar, mandíbula, } \\
\text { dente); cimento, } \\
\text { tendão artificial; } \\
\text { oftalmologia. }\end{array}$ \\
\hline \multicolumn{4}{|l|}{ Metais e ligas } \\
\hline $\begin{array}{l}\text { Aço inoxidável } \\
\text { Liga de titânio } \\
\text { Liga de cobalto } \\
\text { cromo }\end{array}$ & $\begin{array}{l}\text { Alta resistência à } \\
\text { tração, alta } \\
\text { resistência ao } \\
\text { desgaste, energia } \\
\text { de deformação alta }\end{array}$ & $\begin{array}{l}\text { Baixa } \\
\text { biocompatibilidade, } \\
\text { corrosão em meio } \\
\text { fisiológico, perda } \\
\text { das propriedades } \\
\text { mecânicas com } \\
\text { tecidos conectivos } \\
\text { moles, alta } \\
\text { densidade }\end{array}$ & $\begin{array}{l}\text { Fixação ortopédica } \\
\text { (parafusos, pinos, } \\
\text { placas, fios, } \\
\text { hastes);implantes } \\
\text { dentários }\end{array}$ \\
\hline \multicolumn{4}{|l|}{ Cerâmica e vidros } \\
\hline $\begin{array}{l}\text { Alumina } \\
\text { Zircônia } \\
\text { Carbono } \\
\text { Fosfatos de cálcio } \\
\text { Porcelana } \\
\text { Vidros bioativos }\end{array}$ & $\begin{array}{l}\text { Boa } \\
\text { biocompatibilidade, } \\
\text { resistência à } \\
\text { corrosão, inércia } \\
\text { química,alta } \\
\text { resistência à } \\
\text { compressão }\end{array}$ & $\begin{array}{l}\text { Baixa resistência à } \\
\text { tração, alto módulo } \\
\text { elástico, alta } \\
\text { densidade }\end{array}$ & $\begin{array}{l}\text { Ossos, juntas, } \\
\text { dentes, válvulas, } \\
\text { tendões, vasos } \\
\text { sangüíneos e } \\
\text { traquéias artificiais }\end{array}$ \\
\hline \multicolumn{4}{|l|}{ Compósitos } \\
\hline $\begin{array}{l}\text { Fibra de carbono- } \\
\text { Resina termofixa } \\
\text { Fibra de carbono- } \\
\text { termoplástico } \\
\text { Carbono-carbono } \\
\text { Fosfato de cálcio- } \\
\text { colágeno }\end{array}$ & $\begin{array}{l}\text { Boa } \\
\text { biocompatibilidade, } \\
\text { inércia química, } \\
\text { resistência à } \\
\text { corrosão, alta } \\
\text { resistência à } \\
\text { tração. }\end{array}$ & Difícil fabricação. & $\begin{array}{l}\text { Válvula cardíaca } \\
\text { artificial (carbono } \\
\text { ou grafite pirolítico), } \\
\text { implantes de juntas } \\
\text { de joelho (fibra de } \\
\text { carbono reforçada } \\
\text { com polietileno de } \\
\text { alta densidade) }\end{array}$ \\
\hline
\end{tabular}

Segundo Park (1980), a palavra biomaterial pode ser interpretada de duas maneiras: primeiro, material biológico como tecidos e madeiras; e segundo, como material de implante que repõe a função do material biológico. De acordo com esta definição (Cleamson Advisor 
Board for Biomaterials "Definition of the word 'Biomaterials,' " the sixth Annual International Biomaterial Symposium, April 20-24, 1974), "um biomaterial é, sistematicamente, uma substância farmacologicamente inerte para implantação ou incorporação em sistemas vivos".

Para Kawachi (2000), os materiais utilizados na substituição de ossos enquadram-se em uma classe denominada de biomateriais e devem apresentar propriedades físicas e biológicas compatíveis com os tecidos vivos hospedeiros, de modo a estimular uma resposta adequada dos mesmos. Os materiais sintéticos utilizados para esses fins podem ser metais, polímeros, compósitos, cerâmicos e vidros, como mostra a Tabela 2.2.

Em geral, os biomateriais não devem ter uma resposta do tecido hospedeiro e, para tanto, devem se assemelhar quimicamente ao mesmo. As características mais importantes associadas a um material que deverá substituir um tecido ósseo são a porosidade e a capacidade do material implantado de promover íons para o ambiente vizinho. Estas características são especialmente encontradas em um tipo especial de biomaterial: as biocerâmicas.

\section{2 - Biocerâmicas}

A primeira biocerâmica testada foi o gesso de Paris. Os primeiros pesquisadores tomaram por hipótese que a implantação de sais minerais de cálcio e/ou fosfatos nos defeitos ósseos poderia estimular a reparação óssea pelo suprimento de minerais disponíveis que seriam incorporados na regeneração óssea (HULBERT et al, 1982). As biocerâmicas compõem-se de uma extensa gama de materiais, como os monocristais, policristais, vidros, vitro-cerâmicas e compósitos (HENCH, 1993).

A década de 70 marcou o inicio do uso mais intenso de materiais cerâmicos com propriedades que possibilitam a sua classificação como biocerâmicas. A primeira 
biocerâmica com uso muito difundido neste período foi a alumina densa $\left(\propto-\mathrm{Al}_{2} \mathrm{O}_{3}\right)$ (HULBERT, 1970), que se apresenta como bioinerte.

Biocerâmicas são definidas como materiais cerâmicos projetados para alcançar um comportamento fisiológico específico e que são utilizadas como material para manufatura de dispositivos protéticos ou órgão artificial interno. De acordo com Bose et al (2002), Hench (1993) e Zavaglia (1993), aplicações de biocerâmicas para implante encontram-se nas mais diversas áreas - ortopédica, buco-maxilo-facial e odontológica, ou seja, para substituição de articulações, de dentes, reparação de patologias periodontais, reconstrução maxilofacial, substituição e estabilização da mandíbula, fusão espinhal, enxerto ósseo e suporte para enzimas.

Devido ao aumento do número de materiais cerâmicos utilizados como biomateriais e os diversos aspectos envolvidos na interação com os tecidos vivos, têm-se procurado classificá-los em diversos grupos. Assim, em termos gerais, as biocerâmicas são classificadas em bioinertes e bioativas. De acordo com a Conferência da Sociedade Européia para Biomateriais realizada na Inglaterra em 1986, o termo bioinerte não é adequado, já que todo material induz algum tipo de resposta do tecido hospedeiro, mesmo que mínima, devendo, por este motivo, ser evitado. No entanto, o termo ainda é comumente utilizado, tendo sido definido por June Wilson como sendo um material que apresenta uma resposta interfacial mínima que resulta na ligação ou na rejeição do tecido hospedeiro, formando uma cápsula fibrosa ao redor do material. Como exemplos de biocerâmicas bioinertes podemos citar a alumina $\left(\propto-\mathrm{Al}_{2} \mathrm{O}_{3}\right)$, zircônia $\left(\mathrm{ZrO}_{2}\right)$ e dióxido de titânio $\left(\mathrm{TiO}_{2}\right)$. Por outro lado, uma biocerâmica bioativa, termo ainda aceito, é definida como aquela que induz uma atividade biológica específica. Como exemplos destas últimas destacam-se a hidroxiapatita $\left[\mathrm{Ca}_{10}\left(\mathrm{PO}_{4}\right)_{6}(\mathrm{OH})_{2}\right]$, o fosfato tricálcico $\left[\mathrm{Ca}_{3}\left(\mathrm{PO}_{4}\right)_{2}\right]$ e os biovidros (KAWACHI, 2000).

Segundo Hulbert (1982), as biocerâmicas são classificadas em três subgrupos, fundadas na reatividade química delas dentro de um ambiente fisiológico. São elas: A) biocerâmicas bioinertes: alumina e zircônia, B) biocerâmicas com superfície reativa: 
biovidro, $\mathrm{Na}_{2} \mathrm{O}-\mathrm{CaO}-\mathrm{CaF}_{2}-\mathrm{P}_{2} \mathrm{O}_{5}-\mathrm{SiO}_{2}$ e apatita $\mathrm{Ca}_{5}\left(\mathrm{PO}_{4}\right)_{3}$ e C) biocerâmicas reabsorvíeis: $\mathrm{Ca}_{3}\left(\mathrm{PO}_{4}\right)_{2}$. Os materiais cerâmicos podem ser bioinertes, que não interagem com o corpo humano, bioativos, que interagem com o corpo humano ligando-se fortemente aos tecidos, ou reabsorvíveis, quando acabam sendo consumidos pelo organismo após determinado período.

Para Hench (1993), as cerâmicas podem ser agrupadas em 3 classes, que são: inertes, porosas e bioativas, de acordo com a resposta desenvolvida na interface osso/implante. Para três tipos de respostas existem diferentes meios que possibilitam a adesão do sistema musculoesquelético e estas dependem do tipo de material do implante e são classificadas de acordo com a Tabela 2.3.

Tabela 2.3 - Classificação de biocerâmicas (HENCH,1993).

\begin{tabular}{|l|l|l|l|}
\hline $\begin{array}{l}\text { Tipo de } \\
\text { biocerâmica }\end{array}$ & Tipo de fixação & Descrição da adesão & Materiais \\
\hline $\begin{array}{l}\text { Praticamente } \\
\text { inerte }\end{array}$ & Morfológica & $\begin{array}{l}\text { Crescimento ósseo nas } \\
\text { irregularidades da superfície } \\
\text { com ação de adesivo ou por } \\
\text { pressão conveniente no } \\
\text { defeito ou vazio. }\end{array}$ & $\begin{array}{l}\text { Monocristais e } \\
\text { alumina } \\
\text { policristalina, } \\
\text { zircônia. }\end{array}$ \\
\hline $\begin{array}{l}\text { Porosa para } \\
\text { intracrescimento }\end{array}$ & Biológica & $\begin{array}{l}\text { Ocorre o intracrescimento } \\
\text { ósseo, com fixação } \\
\text { mecânica do osso no } \\
\text { material. }\end{array}$ & $\begin{array}{l}\text { Alumina policristalina } \\
\text { porosa e metais } \\
\text { revestidos com } \\
\text { hidroxiapatita. }\end{array}$ \\
\hline Superfície reativa & Bioativa & $\begin{array}{l}\text { Adesão química diretamente } \\
\text { com o osso. }\end{array}$ & $\begin{array}{l}\text { Vidros bioativas ou } \\
\text { hidroxiapatita. }\end{array}$ \\
\hline
\end{tabular}

Uma das primeiras restrições do uso clínico das biocerâmicas está certamente relacionada com a vida útil sob o complexo estado de tensão atuante, a qual geralmente manifesta uma lenta propagação de trinca e fadiga. Manifestações estas que acarretam em fracasso de muitas das aplicações clínicas (HENCH, 1993).

A tenacidade à fratura de um corpo sinterizado constituído de $100 \%$ de $\mathrm{HA}$ apresenta-se em torno de $1,1 \mathrm{MPa} \cdot \mathrm{m}^{-2}$, já em compósitos com até $50 \%$ de $\mathrm{ZrO}_{2}$ são 
relatados em contribuições científicas valores de até $2,8 \mathrm{MPa} \cdot \mathrm{m}^{-2}$, valor este que amplia em muito as possibilidades de aplicação em implantes estruturais (MATSUNO et al, 1996).

Por muitos anos existe um crescente interesse no desenvolvimento e aplicação de corpos cerâmicos porosos que combine microestrutura bem controlada com estabilidade mecânica, química, física e térmica. Um escafolde, segundo Lee (2003), deve possuir cinco fatores, dentre outros, considerados como características desejáveis. São eles: a superfície do escafolde precisa permitir a adesão e o crescimento celular; nenhum componente ou subproduto de sua degradação deve provocar reações inflamatórias ou de toxidade; o material tem de ser manufaturado em estrutura tridimensional; a porosidade deve ser de pelo menos $90 \%$ com elevada área superficial para interação célula-escafolde; espaço para regeneração superficial da matriz extracelular e mínima constrição de difusão durante cultura in vivo; e taxa de regeneração ajustável para combinar com a taxa de regeneração do tecido de interesse.

Os escafoldes cerâmicos podem ser classificados em quatro estruturas básicas: rede fibrosa desordenada (Figura 2.1), estrutura de poros abertos, estrutura de poros fechados, membranas ou, ainda, a mistura deles.

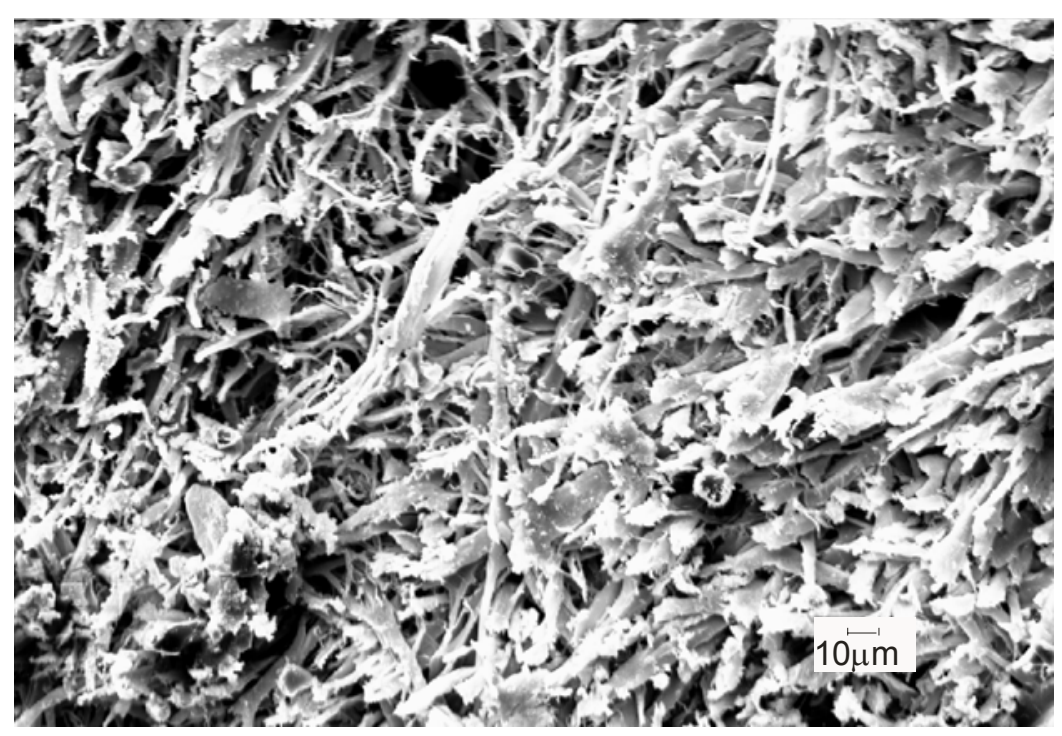

Figura 2.1 - Estrutura porosa de uma estrela do mar (rede fibrosa e desordenada).

A literatura traz informações sobre o tamanho de poros para que haja osteocondutividade. Segundo Hench e Ethridge (1982) a porosidade ótima das biocerâmicas 
está relacionada à necessidade de fornecer um suprimento sanguíneo ao tecido conectivo em crescimento, fator que ocorre em poros maiores que $100 \mu \mathrm{m}$, os quais permitem o desenvolvimento de um sistema de vasos capilares entremeado com a cerâmica porosa. Outros autores afirmam que poros maiores que $100 \mu \mathrm{m}$ e menores que $200 \mu \mathrm{m}$ são necessários para obtenção de uma estrutura porosa para implante (HULBERT, 1970; LIU, 1997). Conforme Klawiter (1976); Daculsi e Passuti (1990), para que ocorra osteointegração os poros devem ser maiores que $50 \mu \mathrm{m}$ ou terem tamanho de 250 a $300 \mu \mathrm{m}$. Para Humbert et al (1971) o tamanho mínimo dos poros é de $100 \mu \mathrm{m}$, mas para que ocorra osteocondução são necessários tamanhos maiores que $200 \mu \mathrm{m}$. Liu (1997) traz a informação de que o macroporo pode ter o limite de $400 \mu \mathrm{m}$. Le Huec et al (1995) colocaram que o volume total de poros da cerâmica tem variado de $20 \%$ a $60 \%$ e o tamanho pode ser de $5 \mu \mathrm{m}-400 \mu \mathrm{m}$. Nessa estrutura ocorreram variações nas respostas à força compressiva e as estruturas com poros maiores apresentaram menor resistência à força de compressão. Binner e Sambrook (2004) divulgaram que tamanho de poros de $100-200 \mu \mathrm{m}$ permitem crescimento de osteoblastos nos poros e para estes autores a presença de dimensões de microporosidade de aproximadamente $1 \mu \mathrm{m}$ na parede do poro é importante para efetivar o crescimento de células. Conforme Hulbert et al (1987) e Simske et al (1997) para que ocorra osteocondutividade é necessário tamanho de poro de 100 a $600 \mu \mathrm{m}$.

É bem sabido que o módulo de elasticidade $(E)$ e a tensão $(\sigma)$ de materiais altamente porosos possuem valores consideráveis abaixo de $(\rho / \rho$ th)E ou $(\rho / \rho$ th $) \sigma$, onde $\rho$ e $\rho$ th são as densidades real e teórica. Isto é uma conseqüência do fato de que o modulo de tensão é uma certa extensão da acomodação interna dos filamentos cerâmicos para reduzir o acúmulo de energia e tensões internas. Segundo Gomide e Zavaglia (2004) o comportamento mecânico de um material pode ser descrito através de sua porosidade, que se caracteriza pela quantidade de vazios existentes no seu volume total.

Boruszewski et al (2005) compararam o módulo de elasticidade, o coeficiente de Poisson e a densidade do osso compacto (13,70MPa, 0,3 e $4,5 \times 10^{-7} \mathrm{~kg} / \mathrm{mm}^{3}$ respectivamente) com o osso esponjoso $\left(1,370 \mathrm{MPa}, 0,3\right.$ e $1,0 \times 10^{-7} \mathrm{~kg} / \mathrm{mm}^{3}$, 
respectivamente). Conforme Yang et al (2001), para o osso compacto, as resistências à tração, à compressão e o módulo de elasticidade são de 60 a $160 \mathrm{MPa}, 130$ a 180MPa e 3 a 30GPa , respectivamente e, para o osso esponjoso, a resistência à compressão e o módulo de elasticidade são de 4 a 12MPa e 20 a 500MPa, respectivamente.

A resistência mecânica dos materiais para implantes deve ser analisada no sentido de que a peça não apresente um módulo de elasticidade excessivamente superior nem inferior ao módulo de elasticidade do tecido ósseo. No primeiro caso, uma peça implantada pode inibir que a ação das forças carregue a parte óssea inserida ao implante, o que leva à reabsorção do osso, conhecido como stress shielding, e sua conseqüente soltura, e o segundo caso pode resultar em fratura do implante (CAMILO, 2006).

Num escafolde a porosidade deve se encontrar bem distribuída, na forma de poros esféricos conectados através de janelas que se formam do contato entre as bolhas e fornecer a característioca de permeabilidade, Figura 2.2. Esta característica é necessária no caso dos implantes, uma vez que a interconexão proporciona canais para o crescimento de tecido ósseo em seu interior e a posterior passagem de nutrientes para a manutenção e renovação dos tecidos (CAMPOS, 2005).

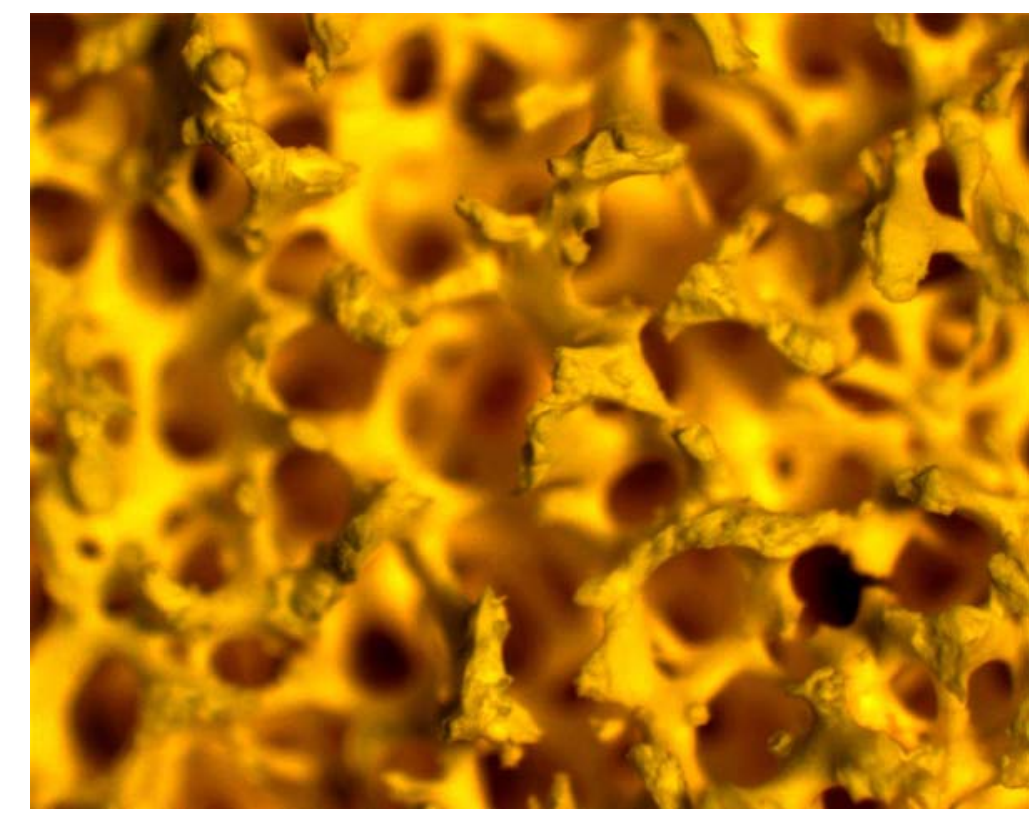

Figura 2.2 - Escafolde de um osso bovino (poros esféricos e conectados). 


\section{3 - Cerâmicas Bioativas}

O termo bioatividade foi usado primeiro para descrever a habilidade que certas composições de vidros, desenvolvidos no fim da década de 60 e início da de 70, têm de se ligarem ao tecido ósseo circundante ao implante, induzindo a formação de uma camada de HA em sua superfície. Hoje, sabe-se que outros materiais cerâmicos como a HA sintética, o fosfato tricálcio sinterizado e algumas vitro-cerâmicas também podem ser bioativos sob certas condições de síntese (ANDRADE e DOMINGUES, 2006).

Materiais artificiais implantados geralmente são encapsulados por tecidos fibrosos ou colágeno. Esta é uma reação normal para proteção do corpo de substâncias estranhas e os materiais implantados são, conseqüentemente, isolados ao redor do tecido ósseo e não ocorre a ligação com o tecido vivo (OHTSUKI et al, 2007).

A habilidade da cerâmica bioativa de criar uma forte união ao redor do tecido ósseo é atribuída a um complexo mecanismo de troca de íons, formação de sílica gel e precipitação de camadas de HA na sua superfície quando estão em contato com fluídos do corpo. A camada de HA mostra ser muito eficiente em promover a osseointegração do implante. Além disso, foi descoberto recentemente que os produtos da dissolução do vidro bioativo exercem um efeito positivo na manifestação de características genéticas, regulando a osteogênese. Um escafolde ideal deve imitar a estrutura trabecular do osso e deve agir como telas onde as células podem aderir, proliferar e promover o fenômeno da regeneração óssea (BROVARONE et al, 2006).

Sabe-se que a superfície de uma cerâmica bioativa (CBA) induz a biomineralização do fosfato de cálcio através da interação com o plasma sanguíneo, que é a primeira fase que interage com a superfície do implante após o mesmo ser inserido em defeitos teciduais. As espécies iônicas inorgânicas dissolvidas no plasma, uma solução saturada em relação aos fosfatos de cálcio, apresentam um grande potencial de precipitação neste meio. Apesar desta condição metaestável para que ocorra a precipitação do fosfato de cálcio, a superfície 
do material tem que induzir uma nucleação heterogênea, seguida pelo crescimento de uma camada de HA (ANDRADE, DOMINGUES, 2006).

O titânio metálico e suas ligas são amplamente utilizados na reconstrução ortopédica por causa da sua excelente biocompatibilidade. Prótese de quadril e implante dentário de titânio metálico e sua liga são clinicamente utilizadas em pacientes. Recentemente foi descoberto que o titânio e sua liga podem formar uma camada bioativa com o tecido ósseo após ele ser submetido a uma modificação da superfície, como tratamento térmico alcalino e oxidação anódica. Entretanto, as propriedades mecânicas do metal são muito maiores que do tecido ósseo, que pode induzir concentração de tensão ao redor do implante e resultar numa falha do implante, mesmo que a mesma seja recoberta por uma camada de material bioativo. Assim, é muito importante o desenvolvimento de materiais bioativos com propriedades mecânicas análogas ao osso cortical humano (YANG et al, 2006).

Os vidros bioativos também são estudados intensamente e são conhecidos por poderem se depositar diretamente ao osso através da nova camada de apatita formada na interface. Eles são mais dissolvíveis e possui maior habilidade de formar ossos do que a HA sintética, que é devido a sua rápida reação superficial inicial com o fluido ósseo (LEE e KIM, 2006). Segundo Macedo (2004), os vidros bioativos ajudam na regeneração óssea e recuperação clínica, com melhores resultados que outros materiais. Este material mostrou ainda a propriedade de osteocondutividade e formação de osso na interface biocompatível para migração óssea e possibilitar que a superfície bioativa seja colonizada por células osteogênicas livres na ferida da cirurgia.

\section{4 - Materiais com Gradiente Funcional (MGF)}

Para Kawasaki (1995), Material com Gradiente Funcional (FGM) é um novo conceito para a obtenção de um material com uma nova propriedade ou função e que não é possível de se encontrar num material homogêneo convencional. 
Em um MGF, a sua composição e estrutura mudam gradualmente sobre o seu volume, resultando em mudanças correspondentes nas propriedades do material. Aplicando as muitas possibilidades inerentes ao conceito de MGF, pode-se criar melhores materiais e com novas funções (MIYAMOTO, 1999). Num MGF as propriedades alteram-se gradualmente de acordo com a posição.

A variação da temperatura ambiente é um fator importante que pode conduzir à deformação dos MGF's, além da carga mecânica. O MGF consiste freqüentemente de algumas camadas com diferente comportamento termoelástico. A mudança de temperatura ambiente pode conduzir para a ocorrência de uma corrente de tensão térmica residual causando uma distorção em cada camada além da deformação de todo o material, devido à característica heterogênea ao longo da espessura dos MGF's (CHU et al, 2001).

Uma idéia para um MGF foi proposta para se obter uma resistência elétrica de material composto onde a cerâmica seria utilizada para o componente que resistirá a alta temperatura e o metal como condutor térmico, com uma variação gradual da cerâmica para o metal. MGF's são então, materiais compostos com características não homogêneas microscopicamente. Mudanças contínuas na microestrutura distinguem os MGF's dos materiais compostos convencionais. A mudança contínua na composição resulta em gradientes nas propriedades do MGF. A Figura 2.3 ilustra as diferenças de microestrutura e propriedade entre um MGF e um material composto convencional (KOIZUMI, 1996).

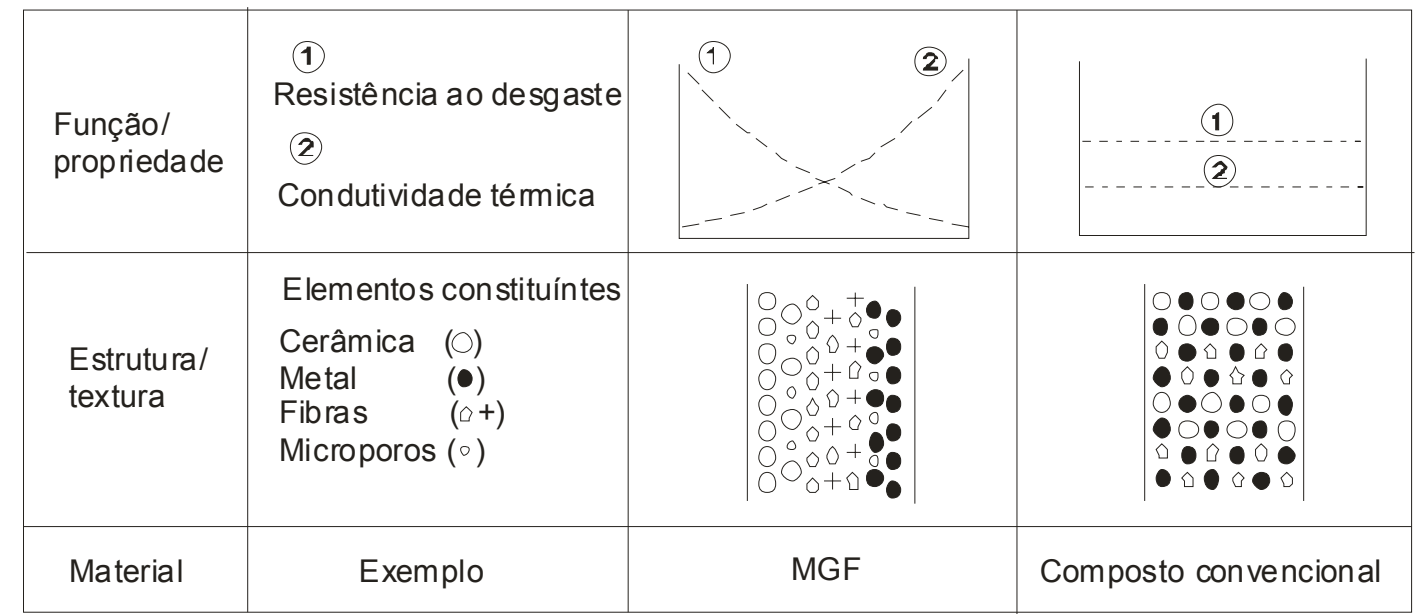

Figura 2.3 - Características do MGF. Fonte (KOIZUMI, 1996) 
A Figura 2.4 ilustra um material com gradiente funcional natural, onde a parte do osso compacto confere ao conjunto a resistência mecânica e a parte porosa permite o fluxo de sangue para a reposição dos minerais e células.

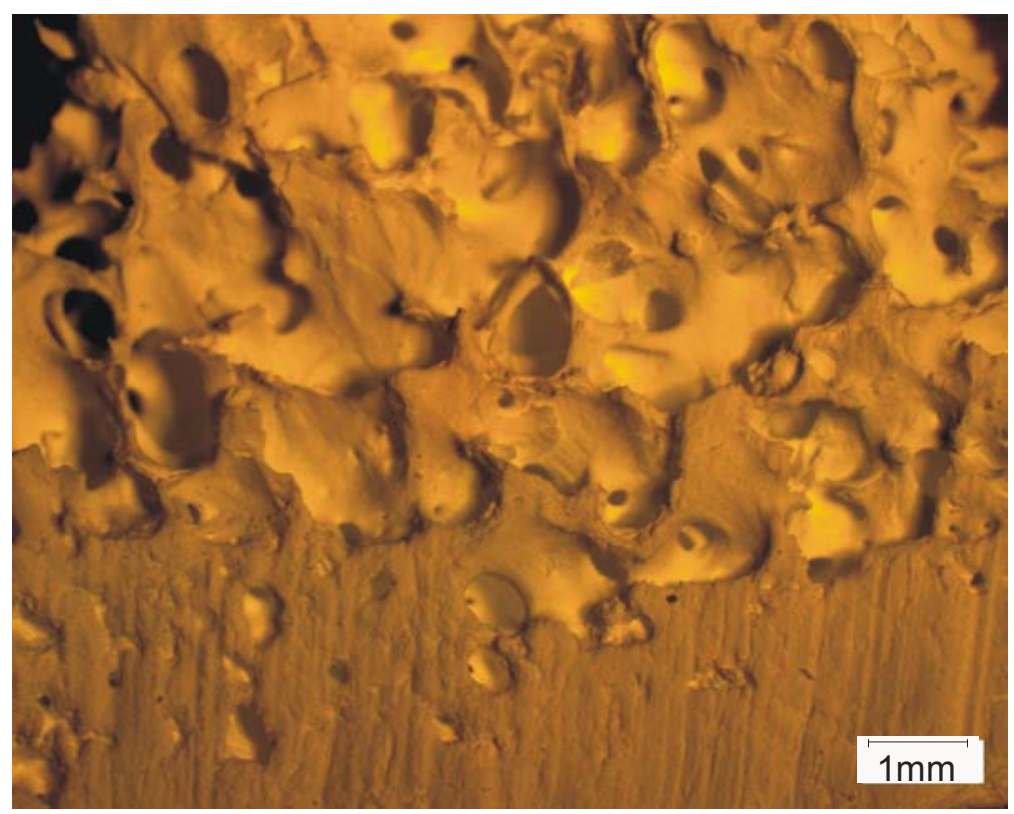

Figura 2.4 - Interface entre o osso compacto e esponjoso.

\section{5 - Conformação de Escafolde}

Pesquisas relacionadas com a fabricação de materiais porosos estão sendo feitas desde 1943, onde Sosnik tentou introduzir poros no alumínio fundido através da adição de mercúrio. Em aplicações biomédicas, o conceito do uso de materiais porosos foi investigado posteriormente. O trabalho de Weber e White de 1972 foi um dos primeiros a mencionar o uso de metais porosos para osteointegração. Numerosas pesquisas sobre materiais porosos iniciaram-se no início da década de 70 e foram baseados em estudos feitos sobre animais envolvendo materiais cerâmicos, poliméricos e metais para serem potenciais candidatos na confecção de implantes porosos que permitam o crescimento ósseo (RYAN et al, 2006).

As membranas porosas podem ser fabricadas por diversas técnicas, tais como o "solgel" e a colagem de barbotina. Já o substrato (tubo poroso) pode ser produzido por 
colagem de suspensões com alta concentração de sólidos ou por extrusão. Além da escolha da técnica de conformação destas partes é preciso, também, selecionar aditivos para a geração de poros.

O mais comum é o uso de substâncias que durante a queima se decompõem e deixam em seu lugar poros, tais como os polímeros orgânicos (ROSA et al, 2006).

Para obtenção de cerâmicas com poros, são apresentadas técnicas dentre as quais é adicionado algum polímero ou substância orgânica na mistura com o material em pó. Em pesquisa realizada por LIU (1997), foi utilizado o Poli Vinil Butirol (PVB) como formador de poros em fabricação de corpos-de-prova porosos compostos por HA. Nesse processo, obtêm-se poros interconectados e de formato esférico.

Outras formas de se obter poros são: através do umedecimento do material em pó com peróxido de hidrogênio; o método gelcasting que pode proporcionar valores de porosidade que podem ultrapassar 90\%-vol; utiliza-se o método da esponja; utilização de coral marinho (Figura 2.5) como matriz para obtenção de estruturas com tamanhos de poros controlados; fabricação de estruturas porosas em ambiente de microgravidade; produção de molde de cera perdida utilizando técnica de prototipagem rápida e a impressão 3D.

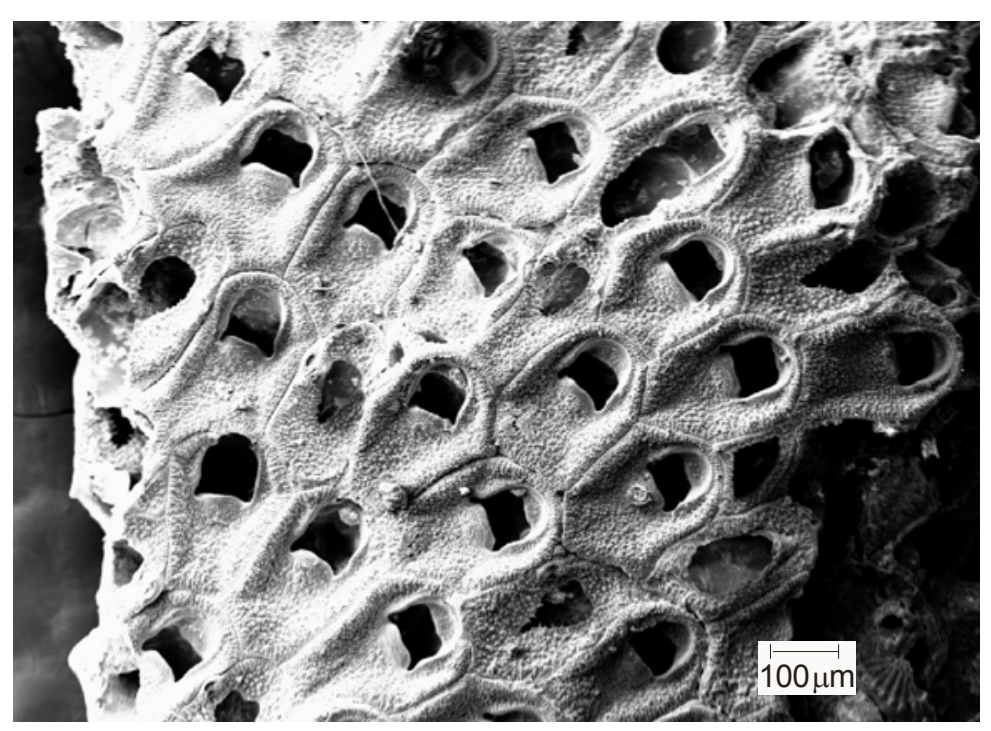

Figura 2.5 - Estrutura porosa de um coral. 
Segundo Monaretti (2005) para obtenção de corpos cerâmicos porosos são empregadas diversas técnicas, as mais difundidas são: adição de um componente degradável e volátil com a temperatura, uso de peróxido de hidrogênio em barbotina, gelcasting, método da esponja, fabricação em ambiente de microgravidade, produção de estrutura em cera perdida pela técnica de prototipagem rápida e prototipagem rápida pela técnica de impressão 3D (3D printing).

Cerâmicas porosas são consideradas materiais com pouca resistência mecânica, isto porque cada inclusão pode ser uma fonte de concentração de tensão. Para aplicações em membranas ou para engenharia de tecidos estes poros devem ser comunicantes e, nestes casos, as junções entre as inclusões ou vazios acentuam ainda mais o estado de concentração de tensões. Na conformação de cerâmicas estruturais avançadas são empregados os processos de prensagem isostática, onde o componente é conformado através da utilização de moldes flexíveis, seguida de usinagem a verde, prensagem uniaxial, prensagem a quente, moldagem por injeção e conformação coloidal, entre outras. As características inerentes a cada um desses processos estão intimamente relacionadas com a formação dos defeitos citados, o que torna então necessário selecionar cuidadosamente cada processo bem como a sua capacidade de atender o desempenho e custo requerido (IKEGAMI et al, 2005).

Segundo Monaretti (2005), na manufatura de escafolde polimérico pelo método de inclusão de agente porogênico, os agentes são adicionados ao material antes da cura e em seguida, pode-se utilizar de lixiviação para a sua remoção, que é facilmente realizado utilizando-se um agente porogênico solúvel em água, como sal, açúcar, ou partículas de gelatina, os quais podem ser removidos embebendo o material curado em água. Quando o material selecionado é uma cerâmica, mistura-se o agente porogênico ao pó cerâmico ou barbotina cerâmica e em seguida, realiza-se a compactação ou moldagem e posteriormente remove-se o agente porogênico no processo de pré-sinterização da cerâmica, através da sua queima ou volatilização, que é facilmente realizado utilizando um agente porogênico orgânico fugitivo. 
A usinagem tradicional e moldagem de polímero convencional não possibilitam a fabricação de peças com estrutura complexa criada em computador (HOLLISTER et al, 2005). Para esse tipo de peça, o método de processamento por prototipagem rápida surge como uma alternativa e ainda possibilita a obtenção de peças com morfologia e estrutura bem controlada (CAMILO, 2006). A Figura 2.6 ilustra o trabalha feito por Hollister et al (2005), onde foi utilizada a técnica de prototipagem rápida.

(a)

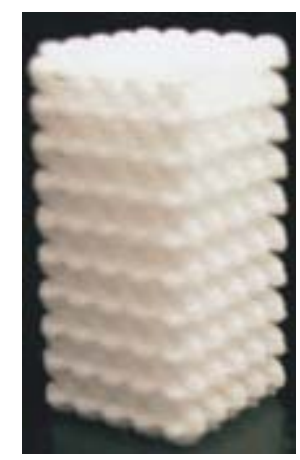

(b)

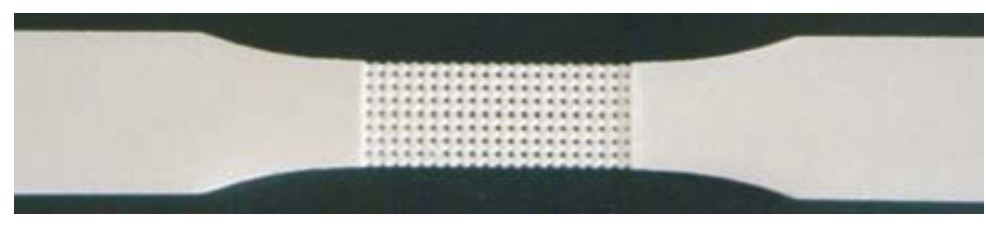

Figura 2.6 - Exemplos de corpos-de-prova de escafolde para ensaios mecânicos: (a) ensaio de compressão e (b) ensaio de tração. Fonte: (HOLLISTER et al, 2005).

Um processo de fabricação típica de produtos cerâmicos é a prensagem isostática, onde se obtém peças de elevada qualidade e uniformidade. O processo trata-se da utilização de um molde flexível (elastomérico) cuja cavidade é preenchida com pós cerâmicos e posteriormente selada. O molde é colocado dentro de um vaso onde o molde é prensado isostaticamente através de um fluído pressurizado que comprime o molde em todas as direções e assim é obtido um produto compactado à verde. A figura 2.7 ilustra o esquema da prensagem isostática. 


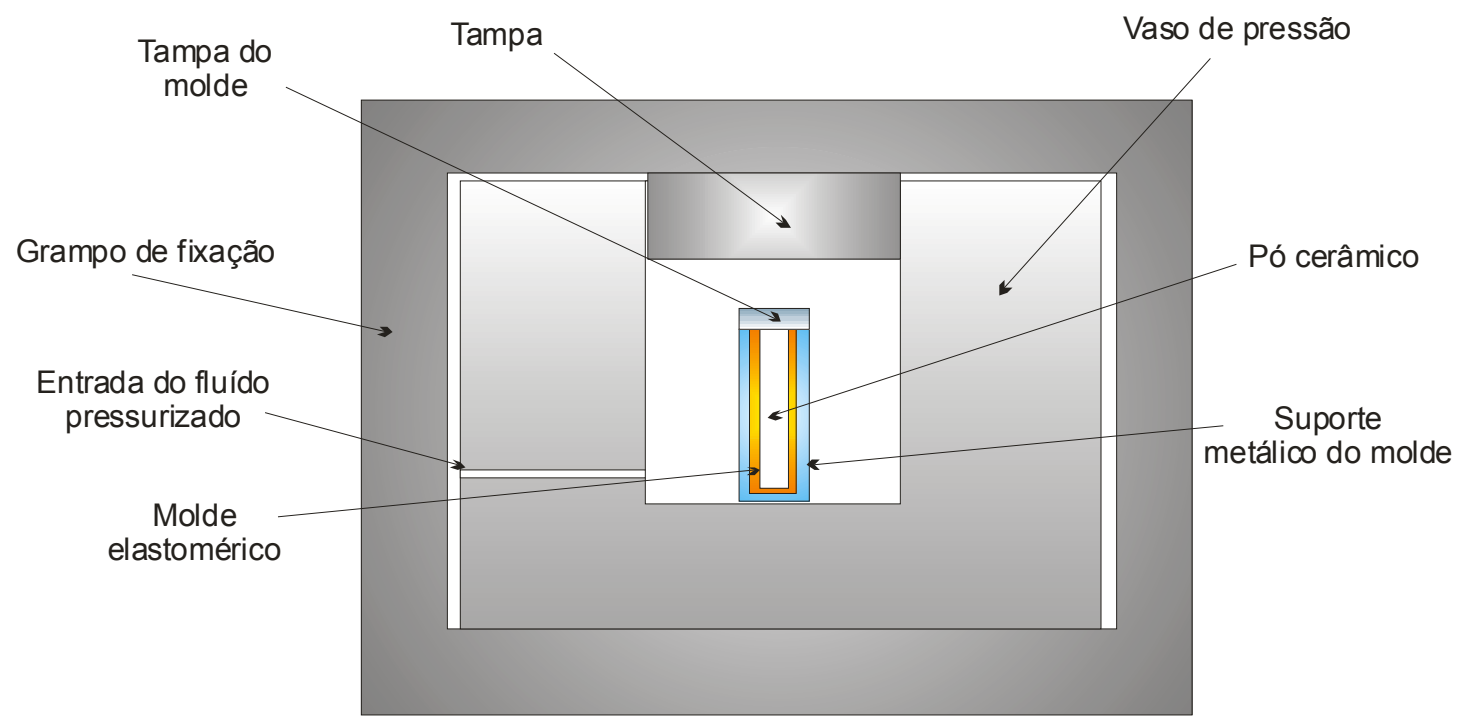

Figura 2.7 - Esquema da prensagem isostática.

\section{6 - Ensaios Mecânicos}

Segundo Fortulan (1997), as medidas dos valores da resistência mecânica são dependentes do tipo de ensaio realizado, da distribuição dos defeitos no material e da distribuição da tensão no corpo-de-prova. Os ensaios comumente utilizados são: ensaio de compressão, flexão, tração, tensão hidrostática e compressão diametral. Para a caracterização mecânica dos materiais cerâmicos, os ensaios de flexão a três pontos e o de compressão uniaxial são os mais empregados.

O ensaio de flexão permite avaliar a contribuição de algum defeito na propagação crítica de uma trinca e é realizado em corpos-de-prova em forma de barra com seção retangular chanfrado ou arredondado, conforme a norma ASTM C1161-90 (1991) e o carregamento pode ser a três ou quatro pontos, conforme Figura 2.8. 


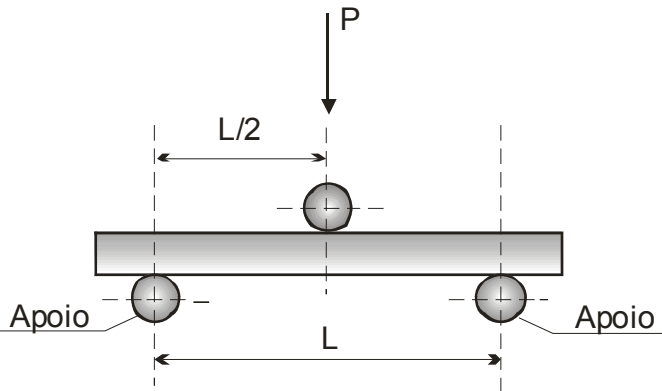

(a)

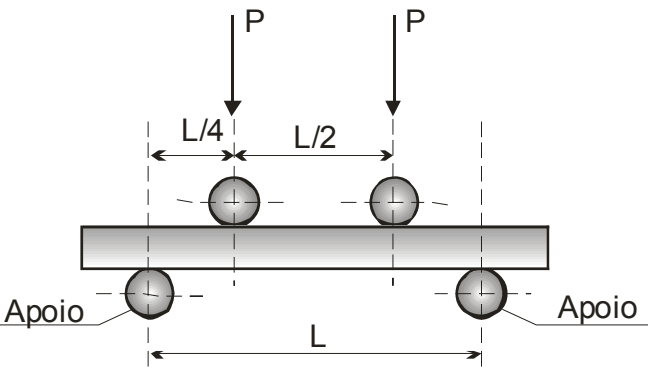

(b)

Figura 2.8 - Modelo de ensaio de flexão: (a) três pontos, (b) quatro pontos. Fonte: [ASTM C116190 (1991)].

A exigência da norma em relação aos dos corpos-de-prova torna o ensaio de flexão de difícil execução devido a alta qualidade dimensional, geométrica e superficial exigida e a manufatura desses corpos-de-prova não poderá deixar defeitos ou trincas na superfície que podem comprometer o resultado do ensaio.

O ensaio de compressão permite analisar o comportamento da resistência mecânica do material e para Awaji \& Nagano (1993) [Apud Fortulan 1997], o ensaio em material cerâmico apresenta a vantagem de não sofrer influência das arestas e quando os corposde-prova são devidamente projetados, podem representar com mais segurança a resistência mecânica de um produto.

A compressão do corpo-de-prova direto no cabeçote da máquina de ensaio pode promover uma concentração de tensão nas bases e isso pode afetar o resultado do ensaio.

Um recurso utilizado para minimizar esse efeito é dar ao corpo-de-prova um formato denominado dumbell, como mostra a Figura 2.9. A seção da base é maior e diminui lentamente em direção ao centro, diminuindo assim a concentração de tensão. Outro recurso seria utilizar assento metálico e rígido de maior diâmetro, onde a pressão é aplicada indiretamente e assim reduz-se a concentração de tensão. 


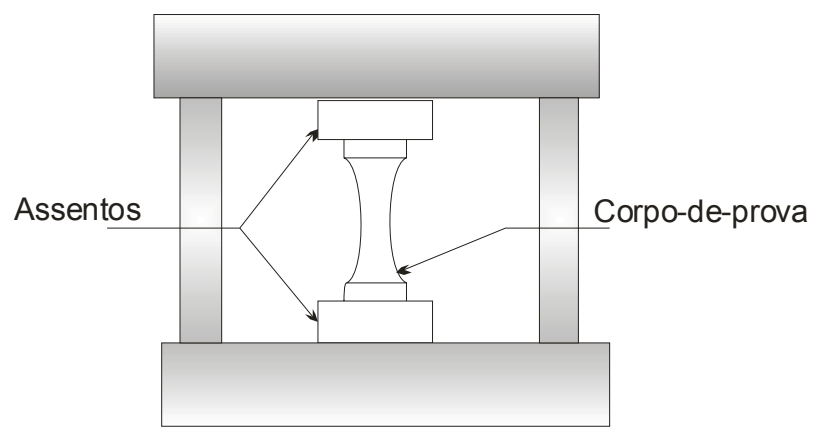

Figura 2.9 - Modelo de ensaio de compressão com a inserção de assentos. Fonte: Fortulan [1997, Apud Awaji; Nagano (1993)]

\section{7 - Estatística de Weibull}

Peças cerâmicas são conformadas através da compactação do material em pó, misturada com algum tipo de aglomerante obtendo-se assim a peça à verde e em seguida é feita a sinterização, onde o material é aquecido próximo a sua temperatura de fusão, para obtermos a peça final. Assim, os componentes confeccionados por esse método geralmente não oferecem os mesmos valores de resistência. Segundo Silva (1998), esses valores devem ser tratados com bases estatísticas, fazendo com que seja assegurada uma probabilidade de ruptura aceitável e assegurar o comportamento dos produtos em serviço. Estes fatores requerem uma técnica estatística para descrever a distribuição de tensão nestes componentes (FORTULAN, 1997). A principal técnica utilizada é a estatística de Weibull, que se baseia na estatística dos valores extremos.

Em 1951, foi publicado no Jornal da Mecânica Aplicada um artigo intitulado "Uma Função Estatística de Larga Aplicação" de autoria do engenheiro sueco Hjalmar Waloddi Weibull, referente ao estudo sobre resistência dos aços; estudo de tração em correntes construídas com esses aços com fórmulas "semi-empíricas" por ele desenvolvidas. A função desenvolvida por Weibull mostrou-se bastante adequada à análise de falhas em equipamentos e, desde então, foi eleita como uma das ferramentas para análise de confiabilidade (PINTO, 2001). 
Sinteticamente, a análise de Weibull é um método estatístico que correlaciona dados específicos de falha com uma distribuição particular, podendo indicar se a falha é um evento prematuro (mortalidade infantil), randômico (aleatório) ou ocasionada por desgaste (final de vida econômica).

No seu trabalho, Weibull procurava uma analogia entre os componentes cristalinos de estrutura de aço e os elos de uma corrente. É importante lembrar que a falha do conjunto é decorrente da falha do componente mais fraco e no caso das cerâmicas, a fratura de uma fibra ou o desenvolvimento de uma trinca isolada devido a uma carga aplicada perpendicularmente ao plano destes defeitos, são similares à ruptura de uma corrente em função do elo mais fraco (SILVA, 1998).

Geralmente a estatística de Weibull é mais aplicada em testes de tração e flexão. A resistência é dependente do tamanho e geometria da amostra. Em adição, uma subseqüente análise de fratura deve ser realizada para caracterizar a origem da fratura. Em cerâmicas avançadas, a resistência é freqüentemente limitada por uma origem de fratura discreta e pode ser intrínseca (porosidade, aglomerados, inclusões, grão grandes atípicos) ou extrínseca (característica superficial, concentração de tensão, eventual impacto ou ambiente adverso) (Fortulan, 1997).

O cálculo que permite encontrar o valor para o módulo de Weibull "m" é feito através da função distribuição de Weibull e corresponde a probabilidade de fratura conforme a equação 2.1 .

$$
P_{f}=1-\exp \left[-V\left(\frac{\sigma}{\sigma_{0}}\right)^{m}\right]
$$

na qual, Pf significa a probabilidade de fratura, $\sigma$ é a tensão aplicada e $\sigma_{0}$ é um parâmetro normalizado (freqüentemente selecionado como a característica da tensão, na qual a probabilidade da fratura é 0,632 ), $m$ é o módulo de Weibull e $\vee$ é o volume. A Figura 
2.10a mostra a distribuição típica de Weibull e com tratamento matemático com logaritmo obtém-se uma nova representação expressa na equação 2.2 e cuja distribuição é representada na Figura 2.10b.

$$
\ln \ln \frac{1}{1-P_{f}}=\ln V-m \ln \sigma_{0}+m \ln \sigma
$$

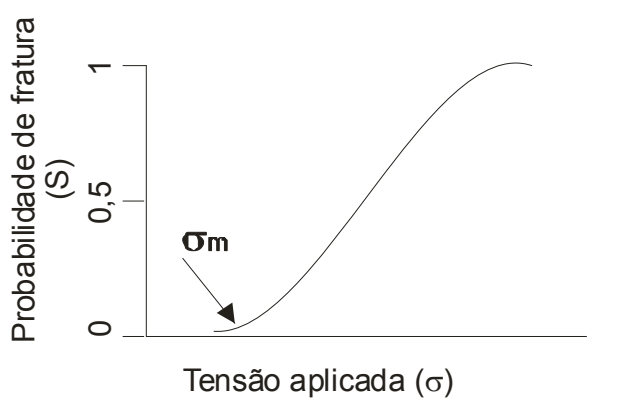

(a)

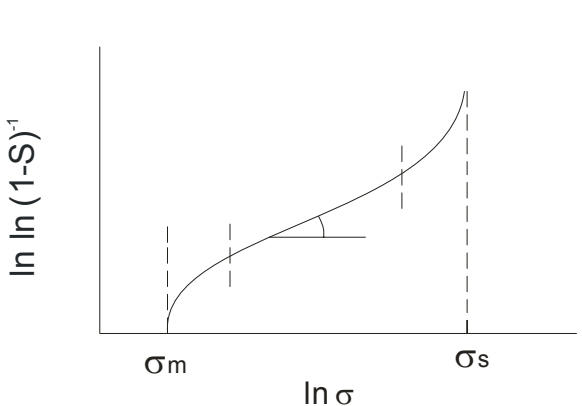

(b)

Figura 2.10 - Distribuição típica de Weibull. Fonte: RICHERSON (apud FORTULAN, 1997) 


\section{3- MATERIAIS E MÉTODOS}

Para se avaliar o desempenho das estruturas com materiais compósitos com gradiente funcional, foram manufaturados corpos porosos com $70 \%$ de porosidade em volume. Os materiais empregados foram a alumina como elemento estrutural, a HA e o biovidro como elementos de bioatividade. Os corpos porosos foram avaliados quanto à resistência mecânica à flexão, para análise do reforço mecânico atribuída pela camada densa e/ou da contribuição da camada porosa na propagação crítica da trinca e o ensaio de compressão para análise da influência dos materiais impregnados na estrutura porosa quanto a resistência mecânica das estruturas.

Foram conformados corpos-de-prova em alumina na forma de barras em três diferentes configurações: densas, porosas com tamanho de poros entre $100 \mu \mathrm{m}$ a $400 \mu \mathrm{m}$ e em duas camadas (densa e porosa). As barras foram submetidas a ensaio de flexão a três pontos para efeito de comparação e verificação do reforço obtido no corpo poroso, ou de maneira inversa, o enfraquecimento do corpo denso pela presença da camada porosa. Para a manufatura dos corpos-de-prova obteve-se pós impregnados com agentes porogênicos através da secagem da barbotina cerâmica e para a conformação foram utilizadas a prensa uniaxial e isostática, seguida de lixiviação (no caso em que foi utilizada a sacarose como agente porogênico) e sinterização. A Figura 3.1 ilustra o diagrama do método utilizado na manufatura dos corpos-de-prova para ensaio de flexão. 


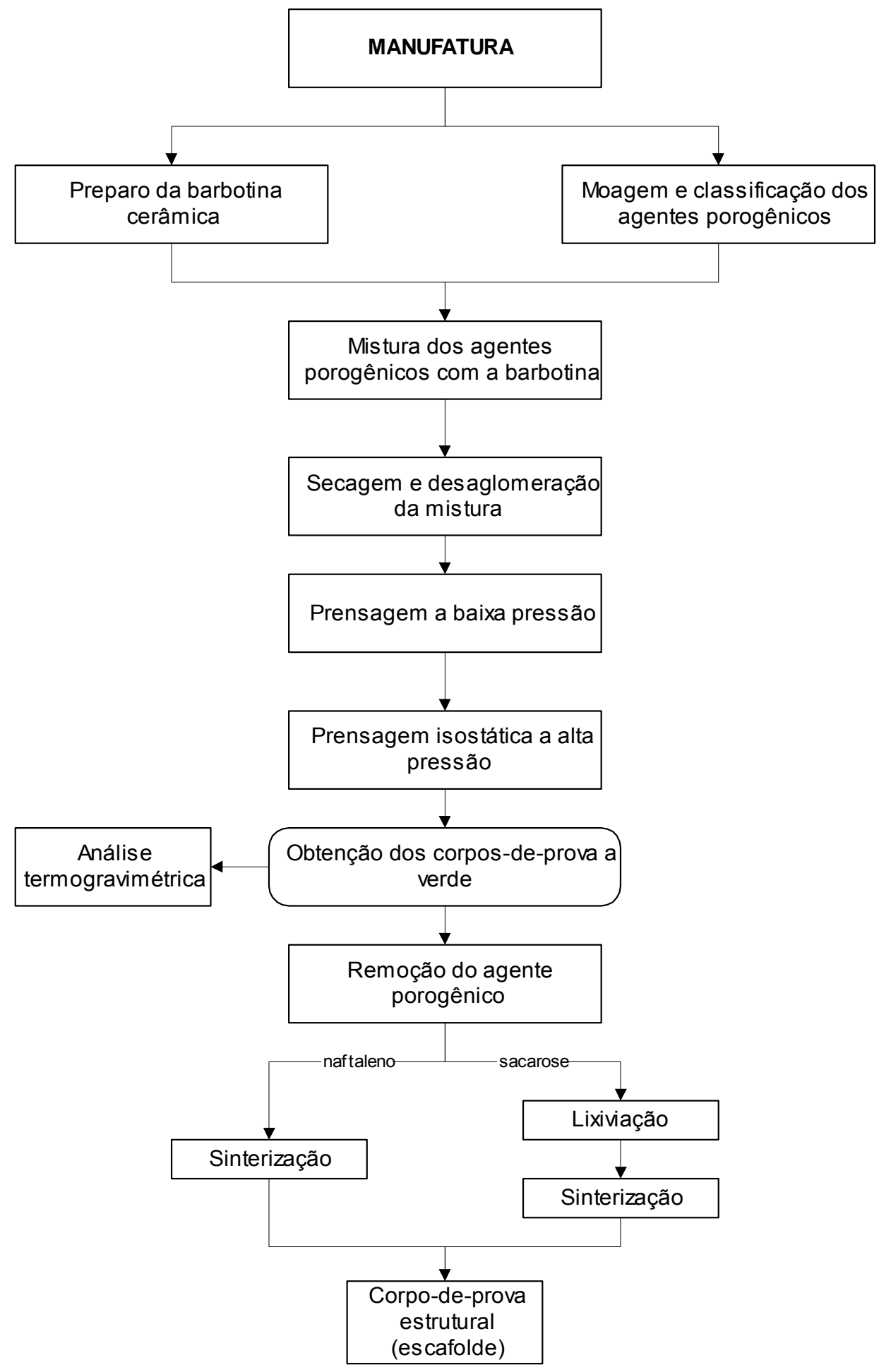

Figura 3.1 - Diagrama do método de manufatura utilizado.

Numa segunda etapa, foram manufaturadas peças de HA e alumina porosa. Estas últimas foram infiltradas com biovidro e $\mathrm{HA}$ e o método de manufatura utilizado foi o mesmo da primeira etapa. Foram manufaturados corpos-de-prova de alumina, infiltrados por HA- 
biovidro, corpos-de-prova de alumina não infiltrados e corpos-de-prova com matriz de HA para ensaio de compressão; amostras de HA porosa, alumina infiltrada por HA-biovidro e amostras de alumina porosa, para análise em Microscópio de Varredura Eletrônica e análise química por EDX ou EDS (Energy Dispersive x-ray detector). O diagrama de fluxo da metodologia empregada neste trabalho é ilustrado na Figura 3.2.

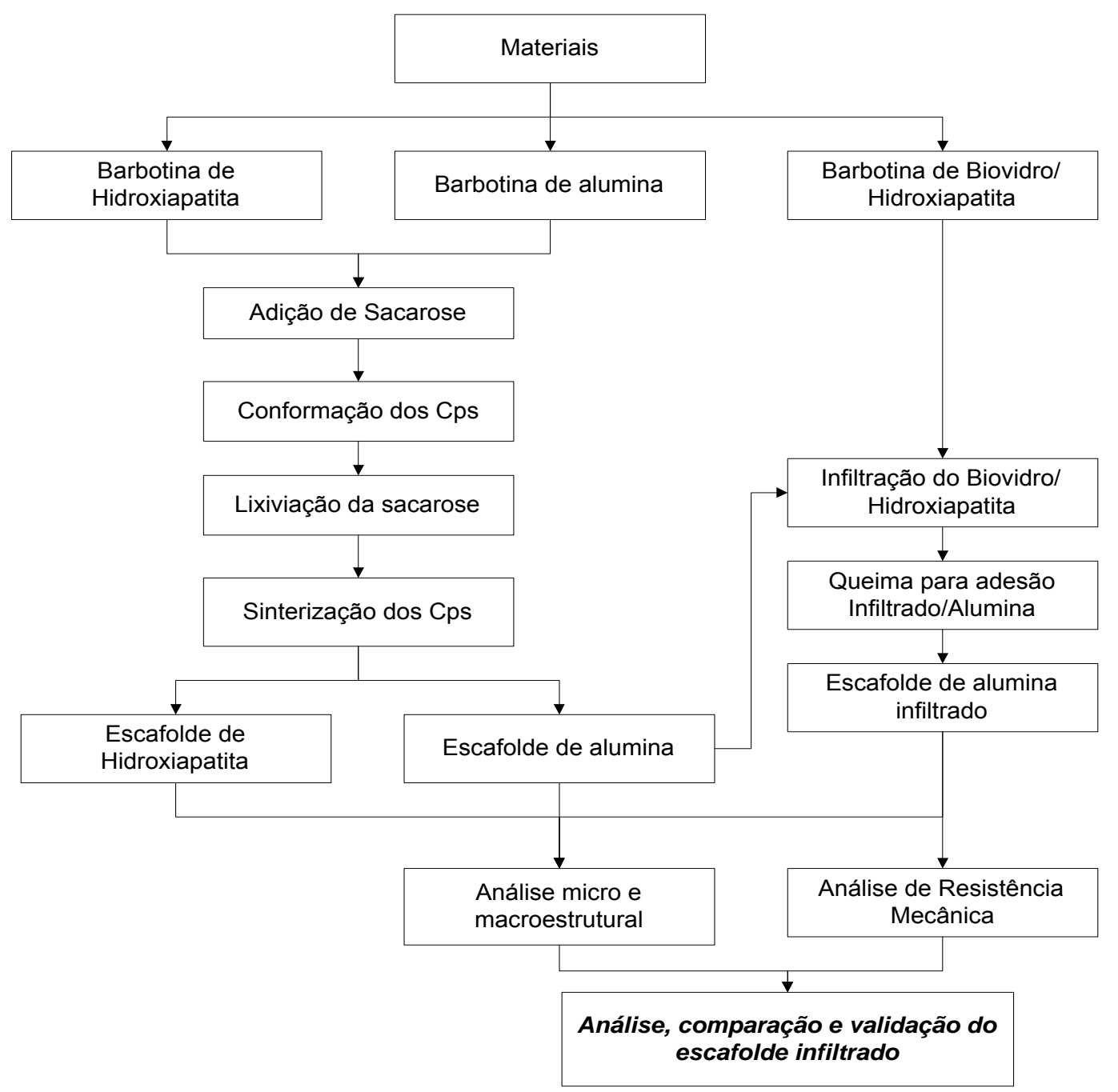

Figura 3.2 - Diagrama de fluxo da metodologia utilizada. 


\section{1 - Materiais}

O custo de aquisição dos materiais utilizados neste trabalho para a fabricação dos escafoldes está na Tabela 3.1 (CAMILO, 2006) e para a fabricação comercial, estes custos devem ser revistos, pois a aquisição é feita em lotes maiores e assim eles diminuem.

Tabela 3.1 - Custo dos materiais utilizados para manufatura dos escafoldes (Camilo, 2006).

\begin{tabular}{|l|c|c|c|c|}
\hline & Data & $\begin{array}{c}\text { Preço } \\
\mathrm{R} \$ / g\end{array}$ & $\begin{array}{c}\text { Preço } \\
\text { US\$ /g }\end{array}$ & Local \\
\hline Alumina Calcinada CT-3000 & $29 / 11 / 2005$ & & 0,00484 & Brasil \\
\hline $\begin{array}{l}\text { Hidroxiapatita (Fluka-Sigma- } \\
\text { Aldrich - 21223) }\end{array}$ & $30 / 08 / 2005$ & 0,336 & & Brasil \\
\hline $\begin{array}{l}\text { Hidroxiapatita (Sigma-Aldrich - } \\
\text { 289396) }\end{array}$ & $30 / 08 / 2005$ & 18,4 & & Brasil \\
\hline $\begin{array}{l}\text { Biovidro (Biogran - 45S5 } \\
\text { Bioglass@) }\end{array}$ & $26 / 01 / 2006$ & 148 & & Brasil \\
\hline $\begin{array}{l}\text { Polivinil-butiral (PVB) (Butvar } \\
\text { B98) }\end{array}$ & $29 / 11 / 2005$ & & 0,01844 & $\begin{array}{c}\text { Brasil/Porto } \\
\text { de Santos }\end{array}$ \\
\hline $\begin{array}{l}\text { Álcool Isopropílico (PA) - ACS } \\
\text { (Labsynth Ltda.) }\end{array}$ & $08 / 09 / 2005$ & 0,011 & & Brasil \\
\hline Sacarose (PA) Marca Synth & $08 / 09 / 2005$ & 0,00496 & & Brasil \\
\hline
\end{tabular}

Como componente estrutural bioinerte dos escafoldes foi utilizada a Alumina Calcinada CT-3000, (Alcoa \& Chemicals Ltda) com diâmetro médio equivalente de partícula de $0,6 \mu \mathrm{m}$, área superficial de 6 a $8 \mathrm{~m}^{2} / \mathrm{g}$ e densidade real de $3,99 \mathrm{~g} / \mathrm{cm}^{3}$. A utilização da alumina se deve pelas suas propriedades mecânicas, bioinércia e facilidade de manufaturar peças.

Como componente estrutural dos escafoldes bioativos foi utilizada a Hidroxiapatita (Fluka-Sigma-Aldrich-21223) com a seguinte composição: Cloro $(\mathrm{Cl}) \leq 0,05 \%$, Sulfato(SO4) $\leq 0,1 \%, \quad \mathrm{Cd} \leq 0,005 \%, \quad \mathrm{Co} \leq 0,005 \%, \quad \mathrm{Cu} \leq 0,005 \%, \quad \mathrm{Fe} \leq 0,04 \%, \quad \mathrm{~K} \leq 0,01 \%$, $\mathrm{Na} \leq 0,05, \mathrm{Ni} \leq 0,005 \%, \mathrm{~Pb} \leq 0,005 \%$ e $\mathrm{Zn} \leq 0,005 \%$. Os escafoldes de $\mathrm{HA}$ serviram para comparação e controle em relação aos escafoldes de alumina nas análises de resistência à compressão. Ressalta-se que a composição química desta HA não atende a norma ASTM 
1185-03 (Standard Specification for Composition of Hydroxylapatite for Surgical Implants), relativamente a concentração máxima de $\mathrm{Cd}(3 \mathrm{ppm})$ e $\mathrm{Pb}(30 \mathrm{ppm})$ porém, devido ao seu relativo baixo custo (Tabela 3.1) optou-se pelo seu uso no desenvolvimento do processo de manufatura dos corpos-de-prova para compressão.

Como componente para infiltração (1), foi utilizada a Hidroxiapatita (Sigma-Aldrich 289396). Este material apresenta pureza que atende a norma ASTM 1185-03 (Standard Specification for Composition of Hydroxylapatite for Surgical Implants) e é comercializado para implantes. No processo de infiltração a quantidade empregada é muito reduzida o que permitiu o emprego deste material de maior valor agregado e resultados mais próximos do ideal.

O componente para infiltração (2) empregado foi o Biovidro (Biogran - $45 \mathrm{S5}$ Bioglass $\left.{ }^{\circledR}\right), 300$ a $355 \mu \mathrm{m}$ (50 - 45 mesh), fabricado pela 3i Implant Innovations Inc Enxerto ósseo sintético reabsorvível, lote 440663 2100-0003. Este material é comercializado para aplicações em implante.

Como ligante cerâmico foi empregado o Polivinil-butirol (PVB) (Butvar B98) com densidade igual a $1,1 \mathrm{~g} / \mathrm{cm}^{3}$, na forma de pó e solúvel em álcool isopropílico. Este ligante, totalmente orgânico, é altamente solúvel em álcool isopropílico e praticamente insolúvel em água. A seleção do PVB foi feita por viabilizar a lixiviação em água da sacarose mantendo a integridade dos escafoldes conformados.

O solvente do ligante e meio líquido da barbotina utilizado foi o Álcool Isopropílico (PA) - ACS da (Labsynth Ltda.), com densidade igual a $0,782 \mathrm{~g} / \mathrm{ml}$, com um máximo de 0,2\% de água. A característica determinante na seleção deste solvente para a confecção dos escafoldes está na baixa solubilidade que a sacarose apresenta neste líquido, o que permite a preparação da barbotina mantendo a integridade dimensional dos cristais de sacarose, ou seja, dos vazios ou poros desejados.

Como solvente para lixiviação do açúcar foi usada água destilada. E, finalmente, como agentes formadores de poros foram utilizados Naftaleno PS (Vetec Química Fina Ltda.), com densidade igual a $1,162 \mathrm{~g} / \mathrm{ml}$ a $20^{\circ} \mathrm{C}$ e a Sacarose (PA) da Synth (LABYNTH 


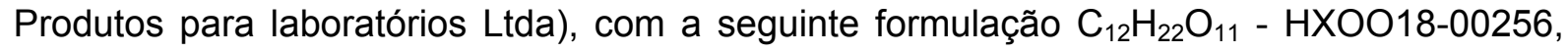
Código Compl: 35801, Família: 0018, Rotação específica $+66,30$ a +66,8 e densidade igual a $1,3327 \mathrm{~g} / \mathrm{ml}$. O máximo de impurezas da sacarose pode ser observado na Tabela 3.2. As impurezas apresentadas pela sacarose foram quase que integralmente removidas do escafolde durante a lixiviação, traços remanescentes após lixiviação e decomposição não influenciam na pureza dos escafoldes, pois todos foram eliminados na sinterização, no segmento da fabricação.

Tabela 3.2 - Máximo de impurezas da sacarose (Camilo, 2006)

\begin{tabular}{|l|c|}
\hline Acidez & $0,0008 \%$ \\
\hline Açúcar invertido & $0,05 \%$ \\
\hline Cloretos $(\mathrm{Cl})$ & $0,005 \%$ \\
\hline Ferro $(\mathrm{Fe})$ & $0,0005 \%$ \\
\hline Insolúveis & $0,005 \%$ \\
\hline Metais Pesados (c/ Pb) & $0,0005 \%$ \\
\hline Perda por secagem & $0,03 \%$ \\
\hline Resíduos de ignição & $0,01 \%$ \\
\hline Sulfatos e sulfitos & $0,005 \%$ \\
\hline
\end{tabular}

\section{2 - Métodos}

Após a seleção do pó e preparo da barbotina, a conformação dos materiais cerâmicos pode ser realizada por diferentes técnicas, dentre as quais podem ser citadas a colagem de barbotina, a colagem em fita, prensagem uniaxial e isostática, injeção e deposição por eletroforese (FORTULAN, 1999).

Neste trabalho, a técnica de conformação dos corpos-de-prova utilizada foi a prensagem uniaxial e isostática. Na etapa inicial, o processo de manufatura dos escafoldes 
cerâmicos será abordado e a seguir a descrição dos métodos de análise serão explanados, como mostra o diagrama da Figura 3.3.

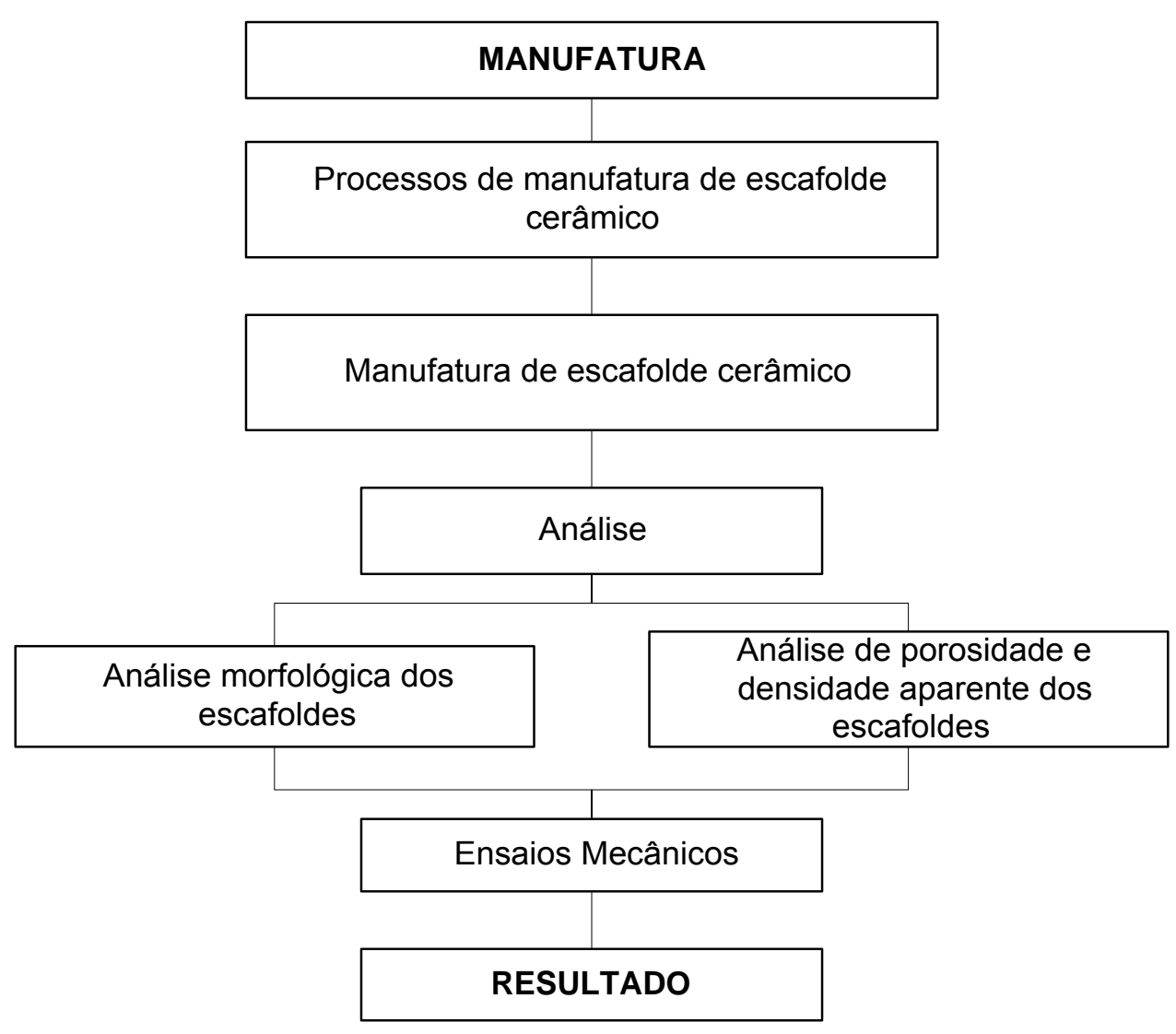

Figura 3.3 - Diagrama descritivo dos métodos utilizados.

\section{3 - Manufatura}

Nos procedimentos para confecção dos escafoldes, foram conformados corpos-deprova denso, poroso e bicamada para o ensaio de flexão e compressão. Para a obtenção de porosidade em cerâmicas são empregadas diversas técnicas, das quais a mais difundida consiste em adicionar um componente disperso que seja degradável e volátil com a temperatura. Este método, durante a queima, permite que o constituinte degradável se decomponha e deixem vazios (poros) no material. Atualmente para componentes 
formadores de poros utiliza-se uma gama enorme de materiais incluindo amido, grafite, sacarose, naftaleno, farinha de trigo entre outros. Todavia, cuidados devem focalizar sempre o controle da pureza dos materiais, particularmente os materiais inorgânicos livres na degradação. Em algumas aplicações, contudo, resíduos inorgânicos podem ser planejados e eles podem favorecer a sinterização se for finamente disperso e reativo. Neste trabalho, optou-se por agente formador de poros por decomposição térmica o naftaleno, devido a sua sublimação e a sacarose, nominalmente $100 \%$ orgânica, com impurezas minimizadas e controladas. Os corpos-de-prova foram conformados por prensagem isostática e a sacarose lixiviada antes da queima.

\subsection{1 - Preparação da Suspensão ou Barbotina}

Para a manufatura dos corpos-de-prova para ensaio de flexão, a mistura, desaglomeração e homogeneização das matérias primas utilizadas para o preparo da barbotina foi realizada em moinho vibratório de jarros, com jarro de polietileno de alto peso molecular (HDPE) de 150ml de capacidade volumétrica total, contendo como elementos de moagem $400 \mathrm{~g}$ de cilindros de alumina $(\varnothing=12 \mathrm{~mm}, \mathrm{~h}=12 \mathrm{~mm})$.

A barbotina foi composta por alumina a 30,0 vol\%; PVB a 3,0 vol\% e álcool isopropílico a 67,0 vol\%. Esta suspensão foi mantida em vibração por 24,0 horas.

Uma segunda classe de barbotina (para a obtenção da estrutura porosa) foi preparada com a adição da sacarose, agentes formadores de poros, na concentração de 75,0 vol\% e agitados mecanicamente através de hélices por 2,0 minutos. Após a mistura, o solvente da barbotina foi evaporado com o auxílio de um soprador de ar quente e simultaneamente desaglomerado manualmente em grãos menores. A secagem dos grânulos foi finalizada em estufa a $80,0^{\circ} \mathrm{C}$ por 30,0 minutos. 
Para a obtenção da parte densa da estrutura, a barbotina sem adição da sacarose teve o solvente evaporado da mesma forma que a segunda classe, o material foi peneirado até passar em malha \#80mesh e assim foi obtido um material em forma de pó.

\subsection{2 - Moagem e classificação dos agentes porogênicos}

Os agentes porogênicos empregados na manufatura dos corpos porosos estruturais cerâmicos (naftaleno e sacarose) foram submetidos ao processo de moagem com almofariz e pistilo para se obter partículas menores. Posteriormente, foram submetidas à classificação de tamanhos, através de peneiras Tyler, a fim de selecionar partículas de tamanhos na faixa de 150 a $600 \mu \mathrm{m}$. A partir disto, elas foram armazenadas em três recipientes distintos: um recipiente contendo partículas na faixa de 150 a $300 \mu \mathrm{m}$, outro com partículas na faixa de 301 a $600 \mu \mathrm{m}$ e um terceiro recipiente armazenou uma combinação de $50 \%$ de partículas na faixa de 150 a $300 \mu \mathrm{m}$ e $50 \%$ de partículas na faixa de 301 a $600 \mu \mathrm{m}$.

\subsection{3 - Conformação dos escafoldes}

Em um molde uniaxial, ilustrado na Figura 3.4 , foi depositada uma quantidade de material suficiente para uma barra com 3,0 mm de espessura que, em seguida, foi prensada uniaxialmente a 25,0MPa, produzindo um corpo-de-prova cerâmico. Posteriormente, o corpo-de-prova foi encapsulada à vácuo em filme elastomérico e compactado em prensa isostática a 100MPa. Para o corpo-de-prova com bicamada, o volume de material cerâmico foi dividido em duas partes iguais. A primeira, referente a camada densa, foi depositada na cavidade do molde e nivelada; a segunda, referente a camada com sacarose foi depositada 
sobre a primeira e nivelada e ambas foram submetidas às mesmas condições de pressão aplicada para o corpo-de-prova com camada única. As barras contendo sacarose (integral e bicamada) foram depositadas em um béquer com água e mantida com leve agitação durante 3,0 horas. Em seguida, as barras foram secas em estufa a $100,0^{\circ} \mathrm{C}$, para posterior sinterização.

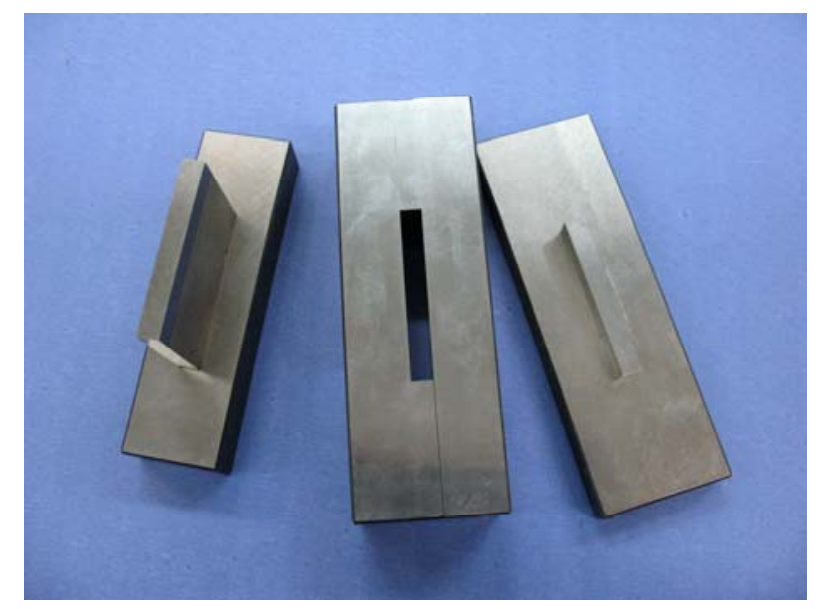

Figura 3.4 - Molde para confecção de barras para ensaio de flexão.

Para análise química por EDX ou EDS (Energy Dispersive x-ray detector) foram confeccionados corpos-de-prova no formato de pastilhas com $6 \mathrm{~mm}$ de diâmetro e $2 \mathrm{~mm}$ de espessura. Para isto foram conformadas pastilhas em prensagem uniaxial a $10 \mathrm{MPa}$, no molde da Figura 3.5, seguida de prensagem isostática a $100 \mathrm{MPa}$ onde as pastilhas foram embaladas a vácuo em filme elastomérico, com patamar na máxima pressão por 1 minuto. A prensagem uniaxial foi necessária para obtenção da forma e a prensagem isostática para a compactação máxima, as dimensões da pastilha a verde foi de $\varnothing 7 \mathrm{~mm}$ e 2,2 $\mathrm{mm}$ de espessura. Os cristais de sacarose utilizados como elementos geradores de poros são rígidos, porém frágeis e tem baixa resistência mecânica. Quando a prensagem uniaxial excede a tensão de $10 \mathrm{MPa}$ ocorre um achatamento da forma dos cristais, a prensagem isostática minimiza a deformação direcionada dos cristais e a rigidez destes auxilia na manutenção da forma do compactado após remoção da pressão de compactação. 


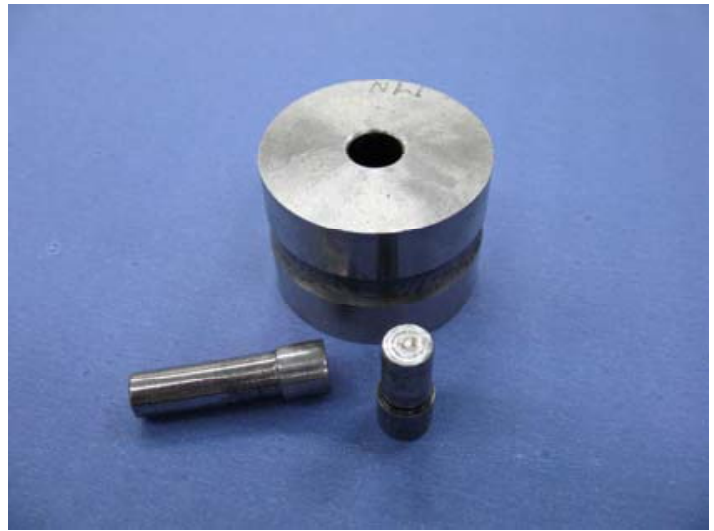

Figura 3.5 - Molde para conformação de pastilhas e corpos-de-prova para compressão.

Para os ensaios de compressão os escafoldes foram conformados uniaxialmente no mesmo molde $(\varnothing 7 \mathrm{~mm} \times 15 \mathrm{~mm})$ com pressão de $10 \mathrm{MPa}$ e posterior consolidação por prensagem isostática a 100MPa. Os escafoldes conformados em formato de pastilha estão ilustrados na Figura 3.6 e para ensaio de compressão na Figura 3.7.

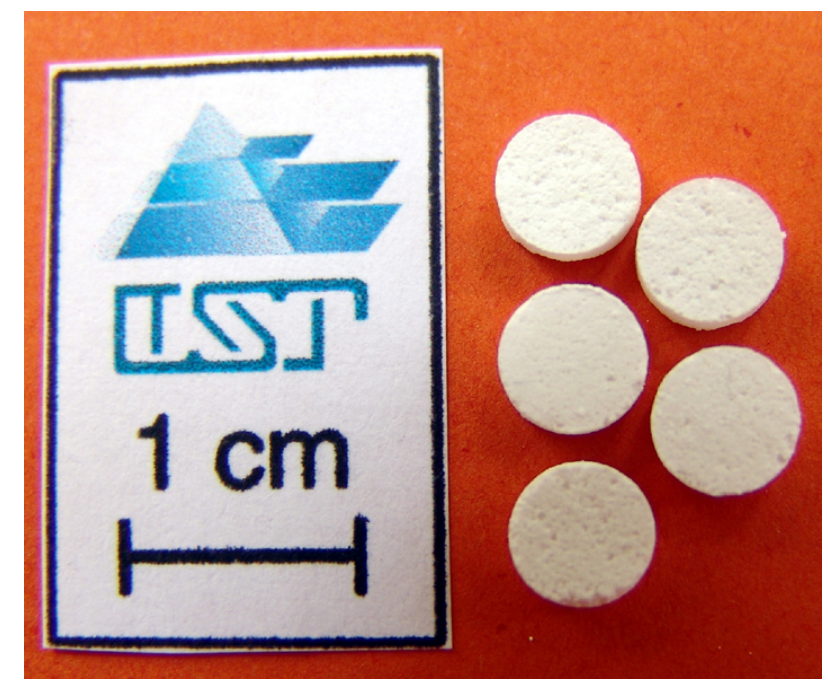

Figura 3.6 - Escafoldes conformados em formato de pastilha. 


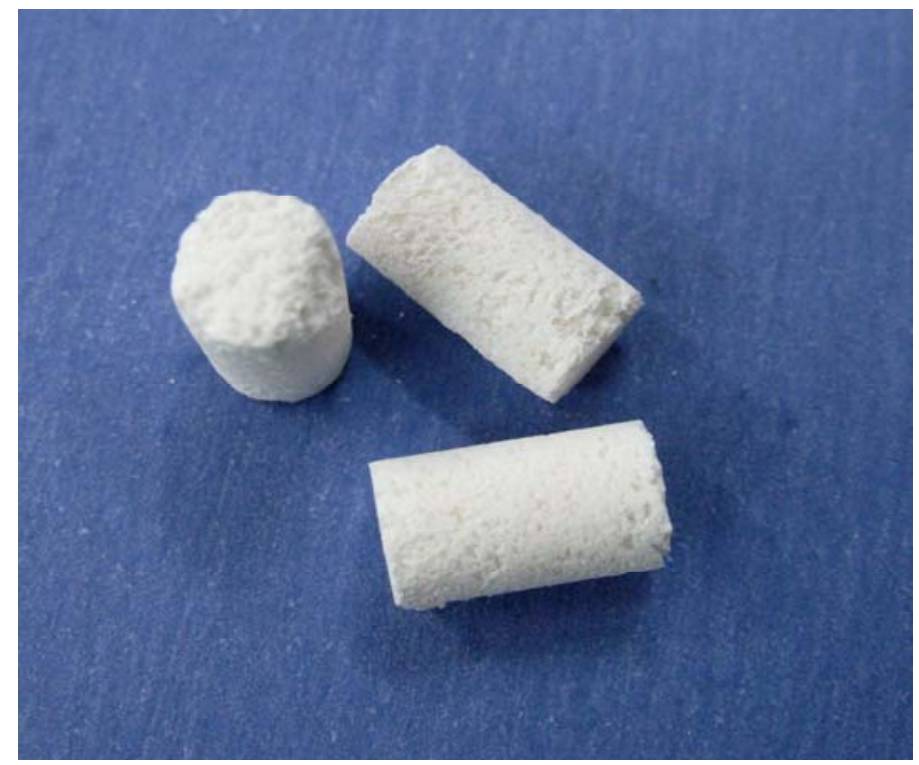

Figura 3.7 - Escafoldes conformados para ensaio de compressão.

\subsection{4 - Análise termogravimétrica (ATG)}

A análise termogravimétrica (ATG) mede a variação da massa de uma substância em função da temperatura e do tempo, sob um controle de temperatura programado. Para a etapa de pré-sinterização, após a conformação dos corpos-de-prova, estes foram encaminhados a ATG, a fim de obter resultados da faixa de temperatura nas quais os materiais voláteis (sacarose, naftaleno e PVB) são eliminados, para assim fazer a programação da curva de aquecimento do forno para sinterização dos corpos-de-prova.

As análises foram feitas no equipamento Shimadzu modelo TGA 51, disposto sobre bancada de granito espesso em suporte metálico com amortecedores de vibrações externas, disponibilizados pelo NETeF - EESC. As amostras foram submetidas a uma taxa de aquecimento de $10^{\circ} \mathrm{C} / \mathrm{min}$ até a temperatura máxima de $600^{\circ} \mathrm{C}$ em atmosfera de ar sintético a uma vazão de $50 \mathrm{~cm}^{3} / \mathrm{min}$. 


\subsection{5 - Programação do forno de sinterização}

A programação do forno para sinterização foi baseada nos resultados obtidos na análise termogravimétrica dos orgânicos.

\subsection{6 - Infiltração da barbotina biovidro/hidroxiapatita}

Os escafoldes foram infiltrados a vácuo com a barbotina Biovidro/Hidroxiapatita e em seguida foram secos em estufa a $80^{\circ} \mathrm{C}$ durante 2 horas. Os escafoldes foram queimados durante 1 hora no patamar de temperatura de $900^{\circ} \mathrm{C}$.

\subsection{7 - Análise macro e microestrutural dos escafoldes}

Para a análise macroestrutural, os escafoldes de alumina foram fraturados e embutidos à vácuo em resina epóxi. Suas superfícies foram aplainadas e polidas com lixas de carbeto de silício na seqüência de \#250, \#320, \#400, \#600 mesh em meio aquoso por 5 minutos em cada uma, seguido de polimento sobre tecidos impregnado com pasta de diamante de $6 \mu \mathrm{m}, 1 \mu \mathrm{m}$ e $1 / 4 \mu \mathrm{m}$.

A macroestrutura, forma e distribuição dos poros dos escafoldes foram caracterizadas por microscopia de varredura eletrônica (MEV). O microscópio utilizado foi da marca LEO modelo 440 disponibilizado pelo CAQI - IQSC - USP. Nesta análise, as superfícies de fratura dos escafoldes examinadas foram previamente metalizadas com uma fina camada de ouro e então rastreadas com um feixe de elétrons, que é refletido e coletado. A imagem obtida representa as características da superfície de fratura. 
As imagens dos escafoldes obtidas por MEV foram então analisadas através do software Image-Pro Plus 4.5 para o estudo macroestrutural, a forma, a dimensão e a distribuição dos poros. Nesta análise consideraram-se somente os poros induzidos, de diâmetros que variaram num intervalo de $10 \mu \mathrm{m}$ ou mais.

\subsection{8- Análise química por EDX}

Para a análise química da superfície de fratura dos escafoldes infiltrados foi realizada utilizando os recursos de EDX/EDS no Microscópio Eletrônico de Varredura. O microscópio utilizado foi LEO modelo 440 disponibilizado pelo CAQI - IQSC - USP. Nele, através do recurso de mapa de EDX, pôde-se verificar a profundidade de penetração e distribuição do infiltrado nos escafoldes.

\subsection{9- Análise da densidade e porosidade aparente dos escafoldes}

A densidade e porosidade aparente foram determinadas através do teste de densidade por imersão, conhecido como princípio de Arquimedes (ASTM C373-88, 1999), utilizando uma balança da marca Mettler Toledo, modelo AB 204 (e=1mg; d=0,1mg) e aparato de suporte de Becker e bandeja disponibilizado pelo LASP/DEMA - UFSCar.

Vinte amostras de cada escafolde foram pesadas, obtendo-se o peso seco (Ps) de cada uma. Posteriormente, estas foram mantidas imersas em água destilada/deionizada por 24 horas e em seguida mediu-se o peso imerso (Pi) e o peso úmido (Pu). Com estes dados obteve-se a porosidade aparente (Pap), a densidade aparente (Dap), o percentual de massa de alumina (Massa\% $\mathrm{Al}_{2} \mathrm{O}_{3}$ ) e a porosidade total (Ptotal), através das equações 3.1 a 3.4 . 
$\mathrm{Pap}=[(\mathrm{Pu}-\mathrm{Ps}) /(\mathrm{Pu}-\mathrm{Pi})] \times 100$

Dap $=[\mathrm{Ps} /(\mathrm{Pu}-\mathrm{Pi})] \times \rho \mathrm{L}$

onde, $\rho \mathrm{L}$ é a densidade da água.

Massa $\% \mathrm{Al}_{2} \mathrm{O}_{3}=$ Dap/D $\mathrm{Al}_{2} \mathrm{O}_{3}$

onde, $\mathrm{D} \mathrm{Al} \mathrm{O}_{3}$ é a densidade da $\mathrm{Al}_{2} \mathrm{O}_{3}$.

Ptotal $=100-$ Massa $\% \mathrm{Al}_{2} \mathrm{O}_{3}$

Os corpos-de-prova foram posteriormente caracterizados fisicamente por porosimetria de mercúrio pelo método de intrusão e extrusão de mercúrio na forma líquida sob pressão controlada (GREGG e SING, 1982), que permitiu avaliar o material quanto a interconectividade, distribuição, volume e tamanho dos poros. Por este método determinamse os diferentes diâmetros dos poros de uma amostra por meio da variação da pressão, conforme a equação de Washburn.

O porosímetro utilizado foi o Micromeritics modelo Pore Sizer 9320, disponibilizado pelo GCCMC - IFSC - USP, através do qual foram mensurados os poros intrínsecos e os poros induzidos dos corpos-de-prova estruturais com diâmetros menores que $10 \mu \mathrm{m}$.

\section{4 - Ensaio de Compressão}

Para os ensaios mecânicos foram confeccionados corpos-de-prova cilíndricos com a mesma estrutura utilizada nos escafoldes com formato de pastilhas, conforme ilustra a Figura 3.8. Foram confeccionados os seguintes corpos-de-prova: alumina (8 cps), HA (7 cps) e alumina infiltrada (7 cps). Para os ensaios utilizou-se uma Máquina de ensaio 
Honsfield tensometer - Serial 88746 - disponibilizada pelo DEMa-UFSCar, no laboratório de cerâmica. Durante os ensaios foi aplicada uma taxa de compressão de $2,5 \mathrm{~mm} / \mathrm{min}$. As amostras tiveram suas faces de apoio planificadas, com pastilhas paralelas de alumínio, fixadas com adesivo epóxi (Figura 3.9).

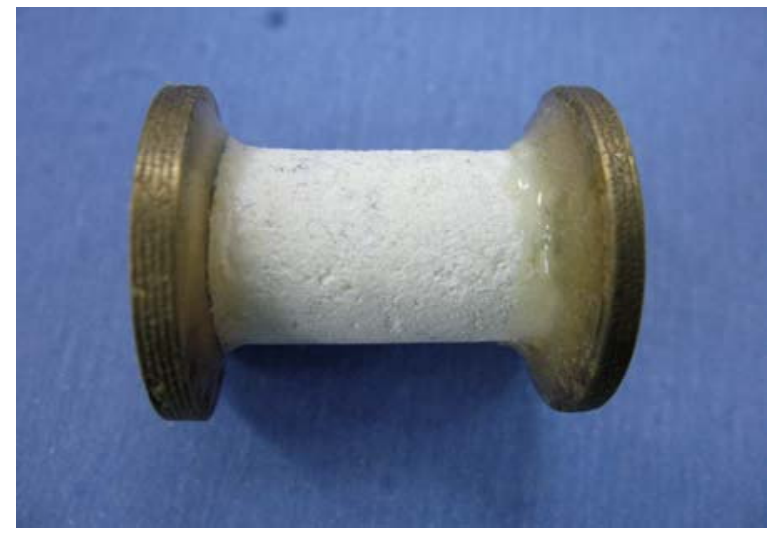

Figura 3.8 - Corpo-de-prova (escafolde) de hidroxiapatita para compressão.

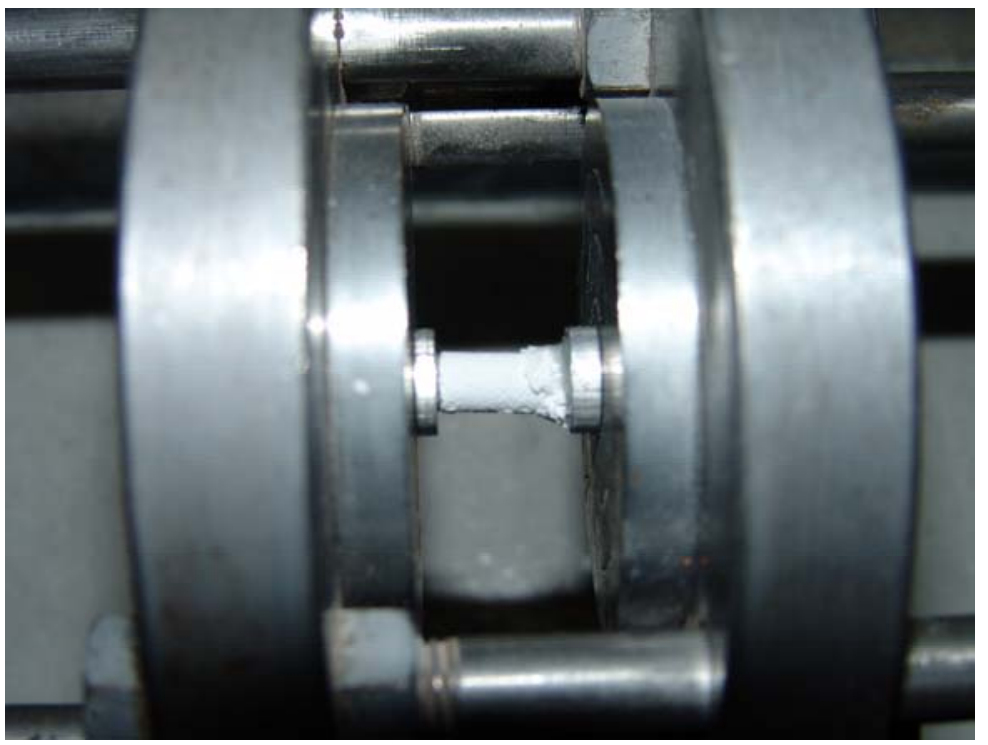

Figura 3.9 - Ensaio de compressão de escafolde de hidroxiapatita. 


\section{5 - Ensaio de Flexão}

Para o ensaio de flexão foram confeccionadas 17 barras porosas, 17 barras com camada dupla e 12 barras densas. O equipamento utilizado para o ensaio de flexão foi uma máquina de ensaio EMIC - do Departamento de Materiais da EESC-USP.

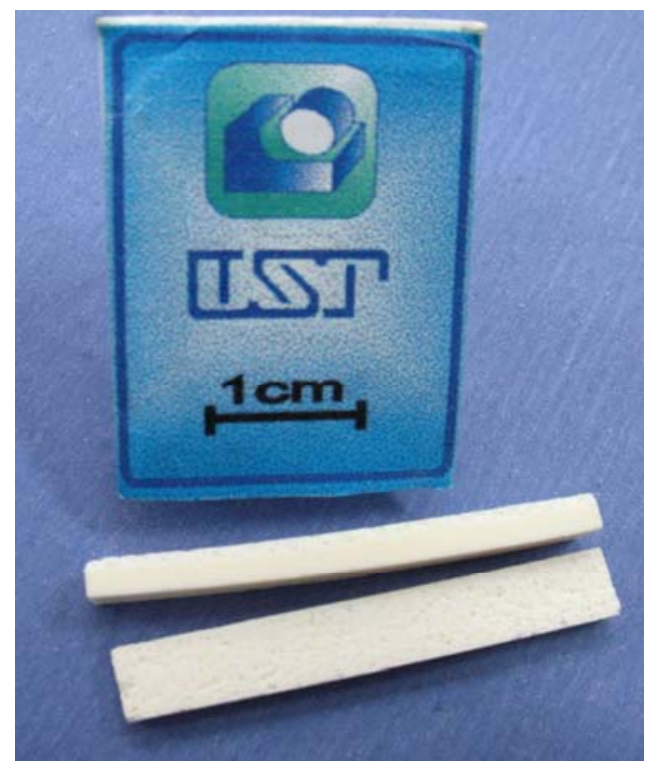

Figura 3.10 - Corpos-de-prova para ensaio de flexão.

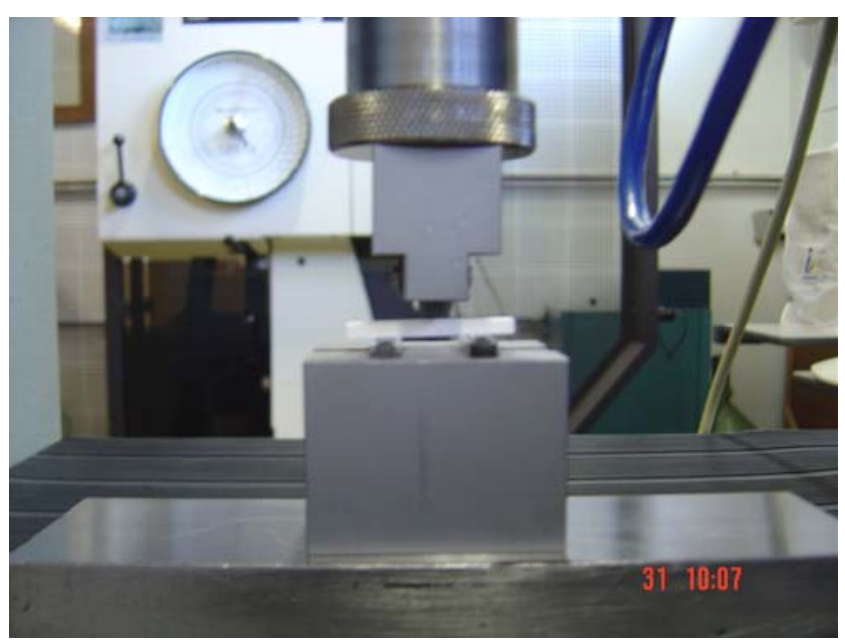

Figura 3.11 - Ensaio de flexão em três pontos. 


\section{6 - Estudo de Caso}

Para a verificação da técnica utilizada para se obter uma estrutura composta com gradiente funcional, foram conformados alguns pinos para implante dentário. Utilizaram-se duas técnicas de conformação, a primeira através da colagem de barbotina em molde de gesso, onde a barbotina é adicionada na cavidade do molde, Figura 3.12, e após a secagem é obtido o implante a verde. A seguir, a parte que será colocada na mandíbula é mergulhada numa barbotina com agente porogênico, para se obter uma estrutura porosa, e então o implante é colocado a vácuo dentro de um invólucro elastomérico e prensado isostaticamente. É feita a lixiviação da peça prensada e a seguir sinterizada.

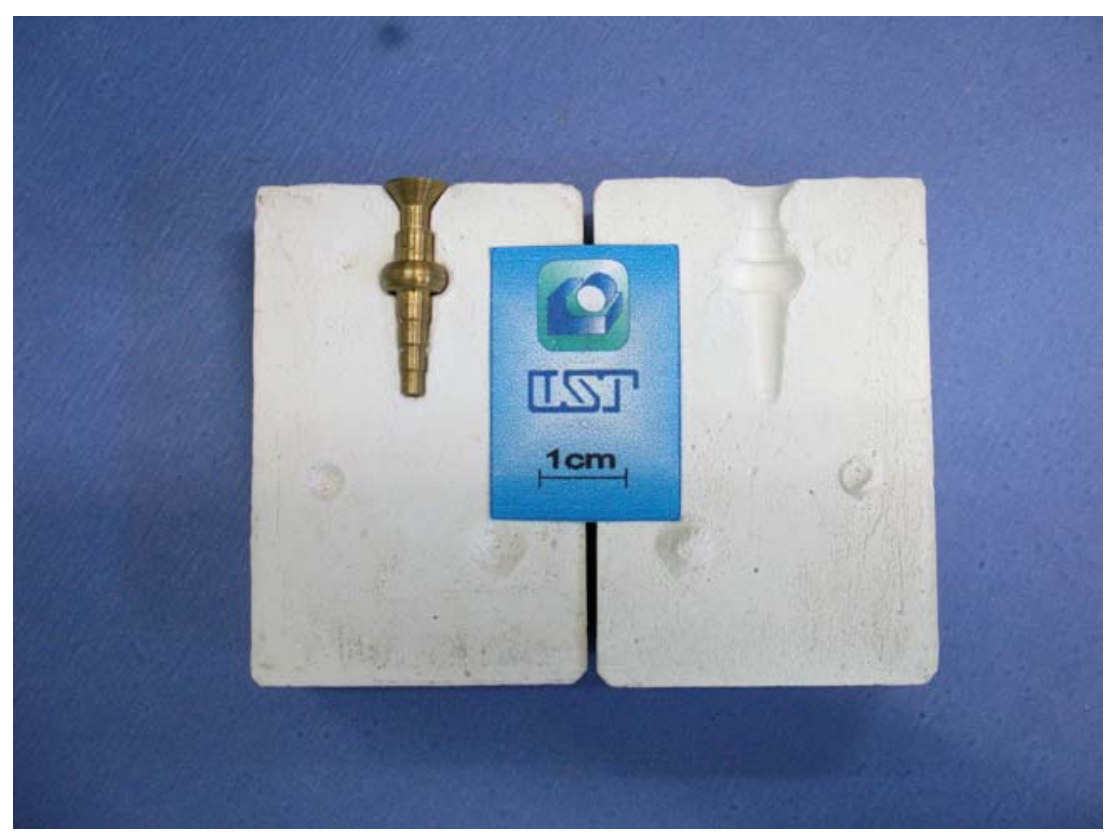

Figura 3.12 - Moldes utilizados para a confecção de implantes dentários por colagem de barbotina.

A segunda técnica utilizada para a confecção do implante foi a prensagem isostática seguida de usinagem a verde. Primeiramente obtiveram-se barras cilíndricas através da prensagem isostática, Figura 3.13, e posteriormente essas barras foram usinadas até obtermos a forma do implante. A máquina utilizada para a prensagem isostática foi 
desenvolvida no Laboratório de Tribologia e Compósitos da Escola de Engenharia de São Carlos e a usinagem feita numa máquina construída no mesmo laboratório (Figura 3.14).

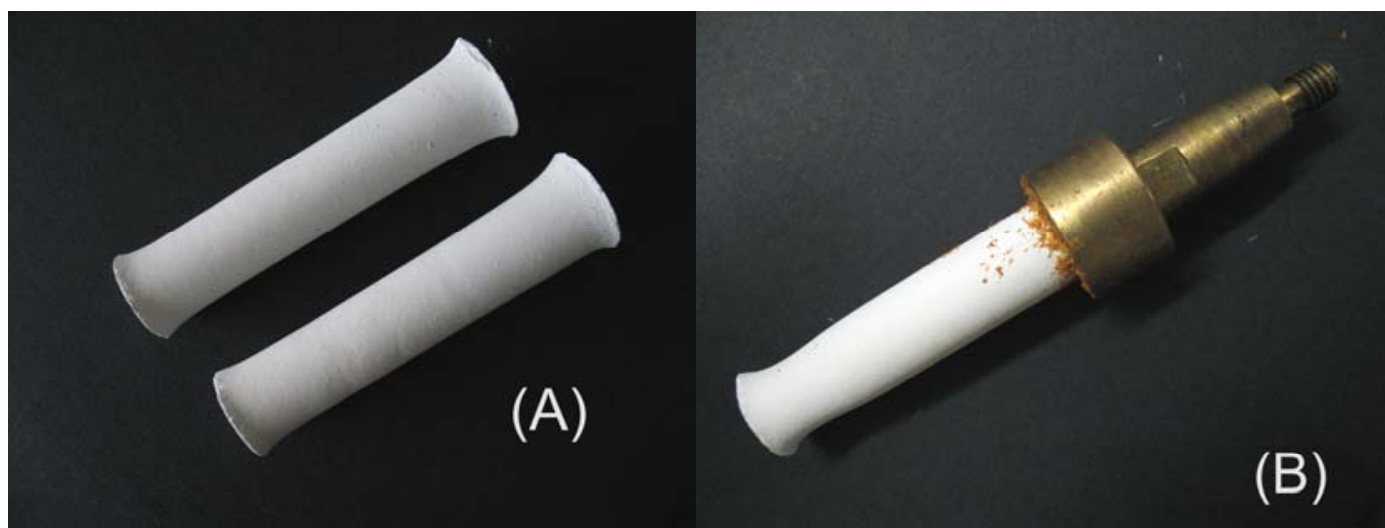

Figura 3.13 - a) Barras prensadas isostaticamente; b) Barra fixada num dispositivo para usinagem.

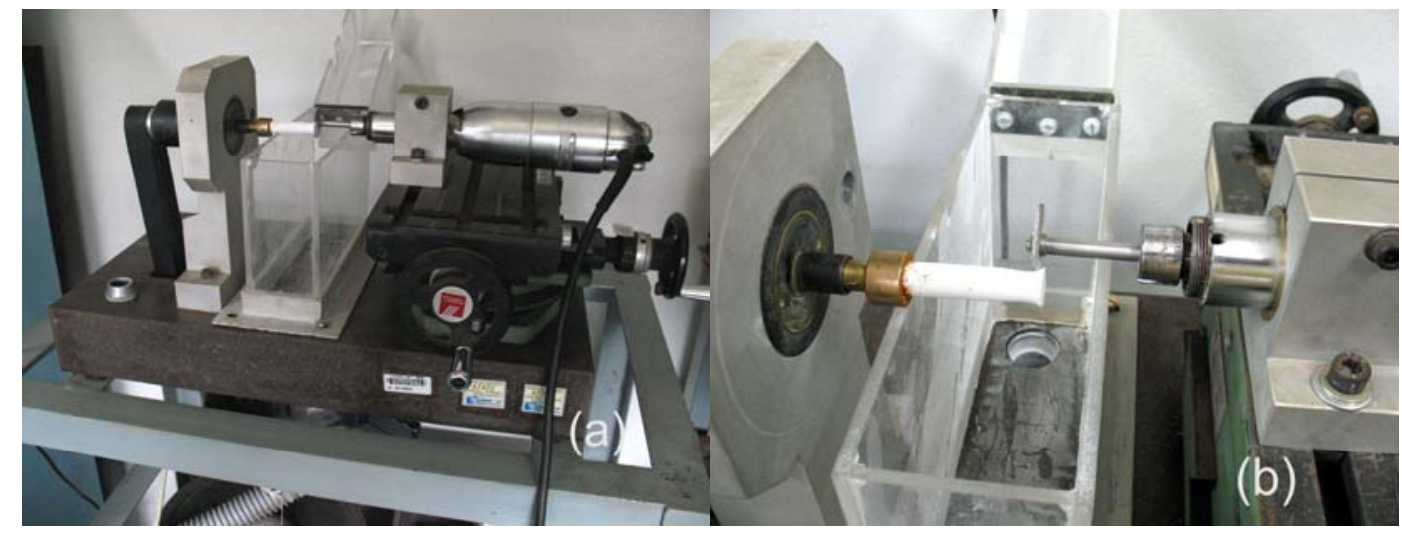

Figura 3.14 - a) Visão geral da máquina; b) detalhe da usinagem da barra.

Um outro estudo de caso foi a confecção de um filtro cerâmico com uma camada densa e outra porosa para filtração tangencial.

O método de conformação selecionado foi o da co-prensagem isostática. Foi projetado um tubo composto por duas camadas filtrantes, a primeira no interior do tubo com poros de 0,1 a $1 \mu \mathrm{m}$ e espessura total de $100 \mu \mathrm{m}$ obtidos a partir de sinterização incompleta, a segunda com pós compostos por partículas formadores de poros, que decompõe com a temperatura, em volume de $50 \%$ e tamanho maior que $47 \mu \mathrm{m}$. A prensagem isostática foi escolhida devido ao desempenho oferecido pelo processo, possibilidade de fabricação de 
multi-camadas (duas para este projeto), homogeneidade em cada camada, transição entre camadas bem definida, e enorme flexibilidade (Fortulan et al, 2005). 


\section{4- RESULTADOS E DISCUSSÕES}

As metodologias descritas no capítulo anterior foram aplicadas para a confecção de corpos-de-prova para análise da estrutura com material compósito com gradiente funcional. Para isso foram confeccionadas barras de alumina densa, porosa e bicamada para ensaio de flexão para verificação da possibilidade de se obter uma barra porosa reforçada com uma camada densa e quantificar esse reforço e/ou analisar se a camada porosa não formaria defeito crítico em demasia que em muito diminuiria a resistência mecânica da camada densa. A seguir foram confeccionadas barras cilíndricas para ensaio de compressão para a comparação da resistência mecânica do escafolde de alumina com a de HA, analisar o quanto a camada infiltrada de hidroxiapatita/biovidro iria alterar a resistência mecânica do escafolde.

\section{1 - Análise Termogravimétrica}

Os resultados das análises termogravimétricas dos voláteis estão apresentados nas Figuras 4.1 a 4.3. onde se destaca o intervalo de temperatura de ocorrência da maior perda de massa dos componentes e cujos valores foram utilizados para a programação da curva de aquecimento do forno para sinterização. 
Através dos gráficos verifica-se que o naftaleno inicia a perda de massa quando a temperatura atinge $58^{\circ} \mathrm{C}$ continuando até $216^{\circ} \mathrm{C}$ e tendo o pico da derivada termogravimétrica com $211^{\circ} \mathrm{C}$. Para a sacarose o processo se inicia com $243^{\circ} \mathrm{C}$ e continua até os $600^{\circ} \mathrm{C}$ com o pico de derivada aos $256^{\circ} \mathrm{C}$. Já para o $\mathrm{PVB}$, o gráfico mostra o início da perda de massa com $212^{\circ} \mathrm{C}$ até $600^{\circ} \mathrm{C}$ e o pico com $412^{\circ} \mathrm{C}$.

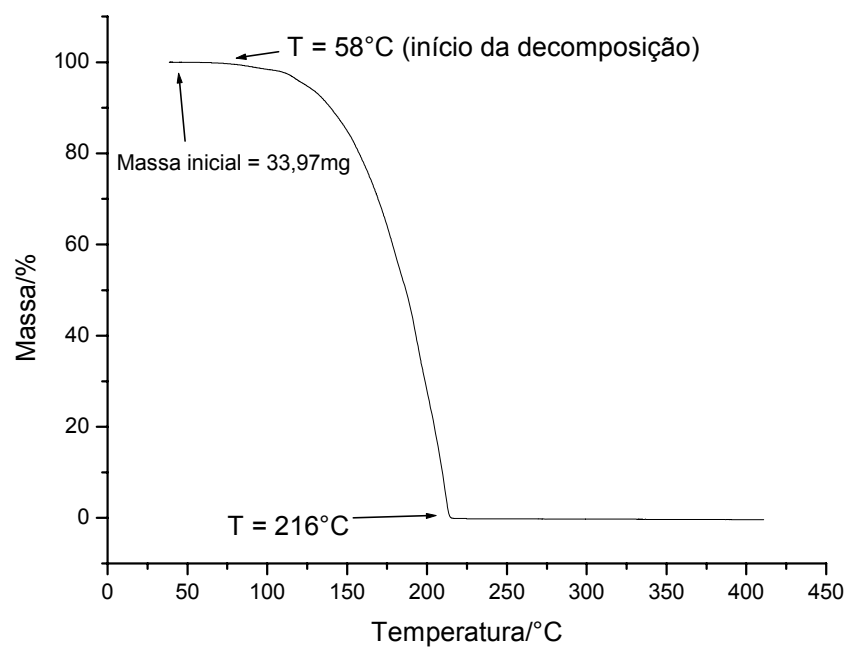

Figura 4.1 - ATG do naftaleno.

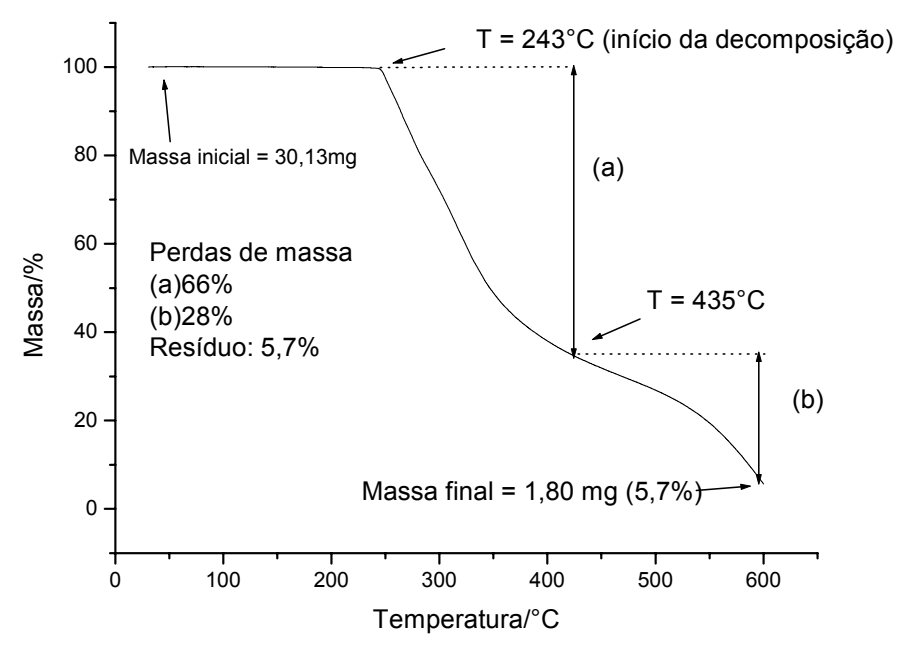

Figura 4.2 - ATG da sacarose 


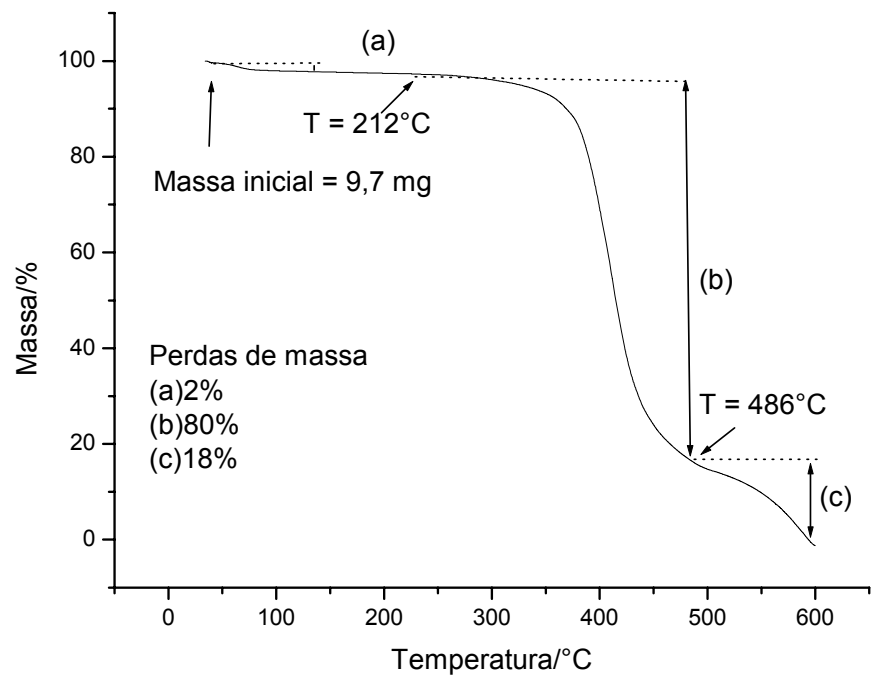

Figura 4.3 - ATG do PVB

\section{2 - Programação do Forno para Sinterização}

A programação do forno de sinterização foi feita com base dos resultados obtidos da análise termogravimétrica da sacarose e está apresentada na Figura 4.4. Nesta figura é apresentada uma condição favorável para a degradação e remoção da sacarose, deixandose a temperatura de maior perda de massa por mais tempo. Os escafoldes de alumina foram sinterizados a $1550^{\circ} \mathrm{C}$ com patamar de 1 hora nesta temperatura. Já os escafoldes de HA foram sinterizados a $1100^{\circ} \mathrm{C}$ com patamar de 1 hora nessa temperatura. Foi adotado o resultado da termogravimetria da sacarose porque a utilização do naftaleno foi abandonada devido ao seu alto grau de toxidade ao ser moído e peneirado. 


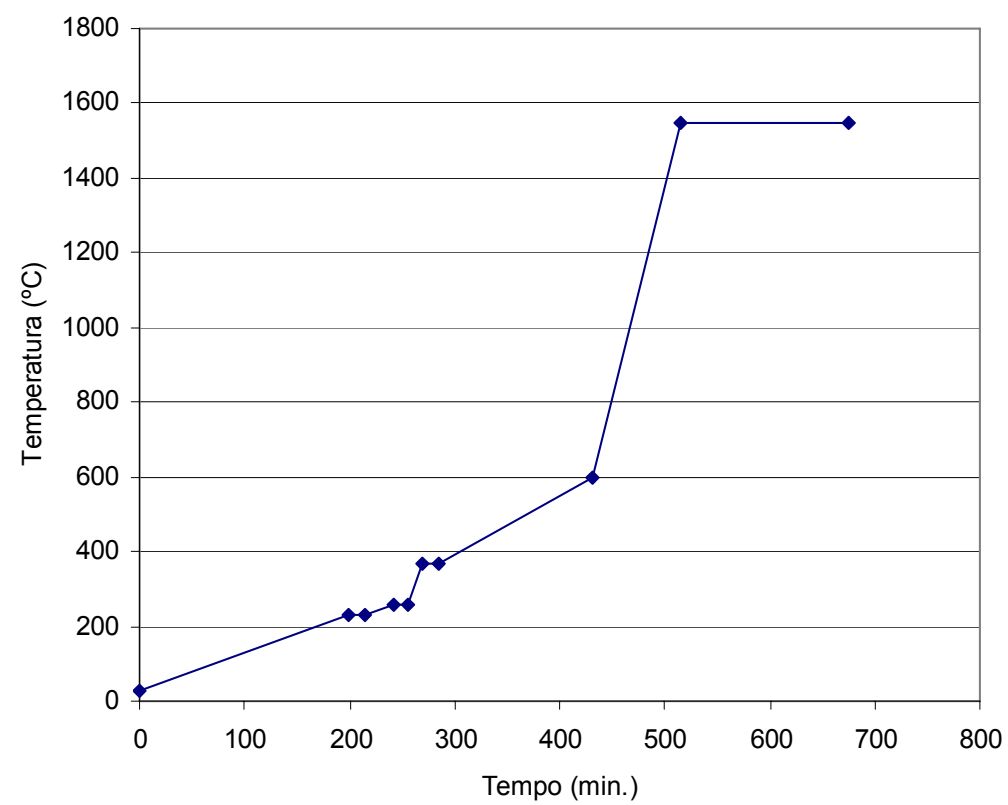

Figura 4.4 - Curva de aquecimento do forno para sinterização dos escafoldes.

\section{3 - Manufatura das Barras para Ensaio de Flexão}

As barras obtidas para ensaio de flexão estão ilustradas na Figura 4.5.

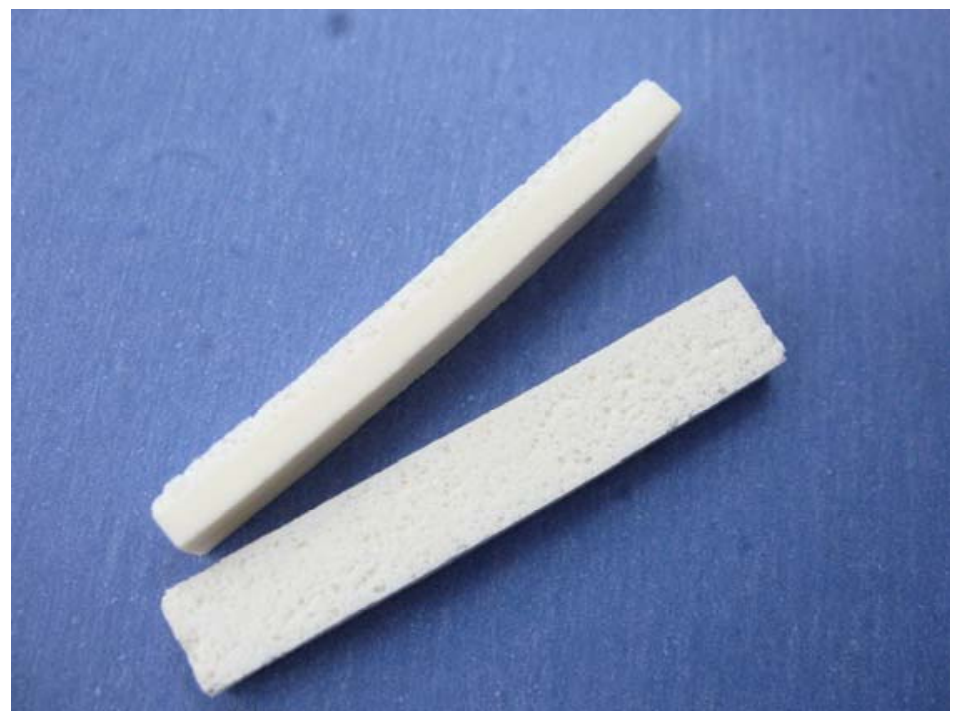

Figura 4.5 - Barras para ensaio de flexão 


\subsection{1 - Retração Linear}

Os valores obtidos das retrações lineares médias dos corpos de prova estão apresentados na Tabela 4.1. Observa-se que a introdução de agentes formadores de poros diminuiu a retração dos corpos de prova, espera-se uma concentração de tensão na camada porosa, esta deverá estar sobre tensão de compressão imposta pela camada densa.

Tabela 4.1 - Retração Linear dos corpos de prova sinterizados em \%.

\begin{tabular}{|l|c|c|c|}
\hline & $\begin{array}{c}\text { Corpos de Provas } \\
\text { (denso) }\end{array}$ & $\begin{array}{c}\text { Corpos de Provas } \\
\text { (poroso) }\end{array}$ & $\begin{array}{c}\text { Corpos de Provas } \\
\text { (bicamada) }\end{array}$ \\
\hline Retração Linear (\%) & 16,55 & 14,74 & 15,12 \\
\hline
\end{tabular}

Para a confecção da barra bicamada surgiu alguns problemas como o destacamento das camadas e envergamento da barra, Figura 4.6, e falhas na camada porosa, Figura 4.7.

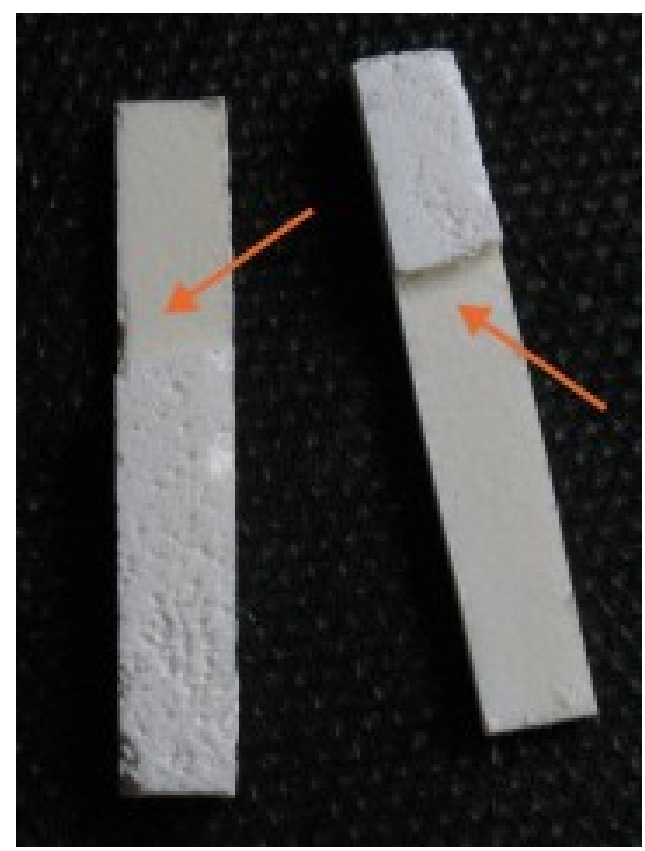

Figura 4.6 - Destacamento da camada porosa. 


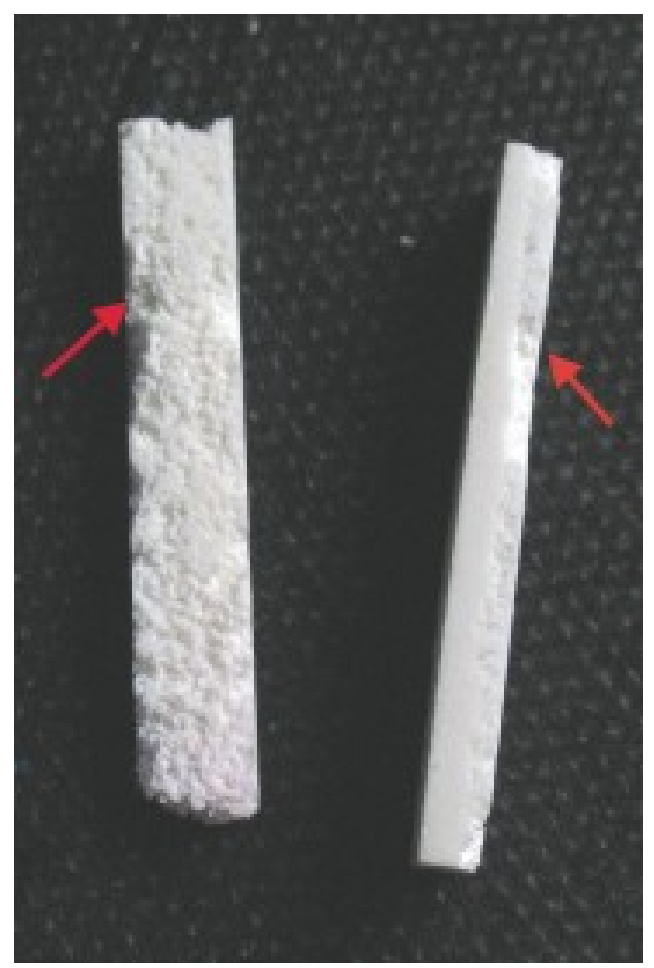

Figura 4.7 - Falha na camada porosa.

O destacamento da camada porosa provavelmente ocorreu devido ao processo utilizado para confeccionar a barra ou pela diferença de retração linear entre a parte densa e porosa. Primeiramente foi colocado o material sem agente porogênico no molde e prensado a 20MPa, a seguir colocado o material com agente porogênico e prensado novamente a 20MPa. Por esse processo muitas barras tiveram a camada porosa destacada e por isso foi alterado o processo, deixando de prensar o material sem agente porogênico e somente nivelar com o pino do molde, e então colocar o material com agente porogênico e prensar a $20 \mathrm{MPa}$.

Com essa alteração do processo, o destacamento da camada porosa praticamente deixou de ocorrer, viabilizando, assim, a manufatura de barras com as camadas densa e porosa (bicamada). 


\subsection{2 - Densidade aparente (Dap ), porosidade aparente (Pap)}

Através da análise realizada pelo teste de imersão (princípio de Arquimedes), obteve-se as médias dos valores: relação entre a densidade aparente pela densidade teórica (Dap/Dth), porosidade aparente (Pap) e porosidade fechada, apresentada na Tabela 4.2. Para os corpos porosos observa-se que $23,0 \%$ dos poros são fechados e para a bicamada $29,0 \%$ são poros fechados

Tabela 4.2 - Densidades medidas.

\begin{tabular}{|l|c|c|c|}
\hline & $\begin{array}{c}\text { Porosidade } \\
\text { Aparente }(\%)\end{array}$ & $\begin{array}{c}\text { Porosidade } \\
\text { Total }(\%)\end{array}$ & $\begin{array}{c}\text { Dap/Dth } \\
(\%)\end{array}$ \\
\hline Corpos de Provas (denso) & 0,692 & 3,29 & 96,71 \\
\hline Corpos de Provas (poroso) & 45,342 & 58,95 & 41,05 \\
\hline Corpos de Provas (bicamada) & 21,226 & 30,05 & 69,95 \\
\hline
\end{tabular}

\section{4 - Ensaio de Flexão}

Realizou-se a ruptura de 12 corpos-de-prova densos, 17 corpos-de-prova bicamadas e 7 corpos-de-prova porosos. Obteve-se a distribuição de Weibull bem como a determinação do módulo de Weibull. A análise prévia da integridade dos corpos-de-prova e a subseqüente análise da fratura permitiu uma diminuição no número de experimentos efetuados e assegurou a confiabilidade dos resultados obtidos. A Figura 4.8 ilustra a distribuição e o módulo de Weibull. Em a) para os corpos-de-prova densos, em b) para os corpos-de-prova porosos e em c) para os corpos-de-prova bicamadas. Para os corpos-de-prova densos encontrou-se uma tensão de fratura a flexão média de $0,26 \mathrm{MPa}$ e $\mathrm{m}=8,4$; para os corposde-prova porosos, uma tensão de fratura a flexão média de $0,028 \mathrm{MPa}$ e $\mathrm{m}=3,5$ e; para os 
corpos-de-prova bicamadas, tensão de fratura a flexão média de 0,069 MPa e m=5,2. Empregou-se a equação 01 para a determinação da resistência a flexão.

$$
S=\frac{3 P L}{2 b d^{2}}
$$

Onde: $S$ = resistência, $P$ = carga na ruptura, $L$ = distância entre os apoios,

$b=$ largura do corpo de prova, $d=$ espessura do corpo de prova .

O ajuste da equação da reta da linha de tendência na Figura 4.8 foi obtido pelo método de mínimos quadrados. Os valores de módulo de Weibull para materiais cerâmicos policristalinos ocupam valores na faixa de $3<\mathrm{m}<15$. Quanto maior for o valor de $\mathrm{m}$, maior será sua confiabilidade. Quanto menor for o valor de $\mathrm{m}$, maior será o espalhamento de valores. Para os corpos-de-prova densos foram obtidos os maiores valores de resistência à flexão e também o maior valor do Módulo de Weillbull, com os corpos-de-prova porosos obteve-se uma queda acentuada dos valores de resistência e do espalhamento dos valores e para os corpos-de-prova bicamadas, um valor intermediário.

Uma analogia, aproximada, reduzindo-se pela metade as espessuras do corpo denso e do corpo poroso na equação da resistência (01), teremos a soma de um quarto (1/4) de cada resistência, ou seja, $(176+23,8) / 4 \mathrm{MPa} \Rightarrow 49,95 \mathrm{MPa}$. Nos ensaios foi obtido um valor de 49,7 MPa, o que sugere que a incorporação da camada porosa influenciou significativamente pouco na resistência mecânica média porém aumentou significativamente seu espalhamento de valores. 


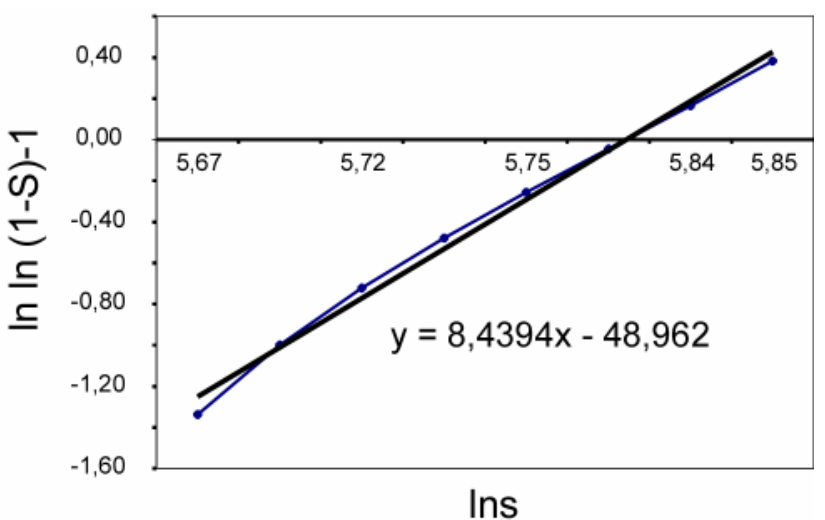

a)

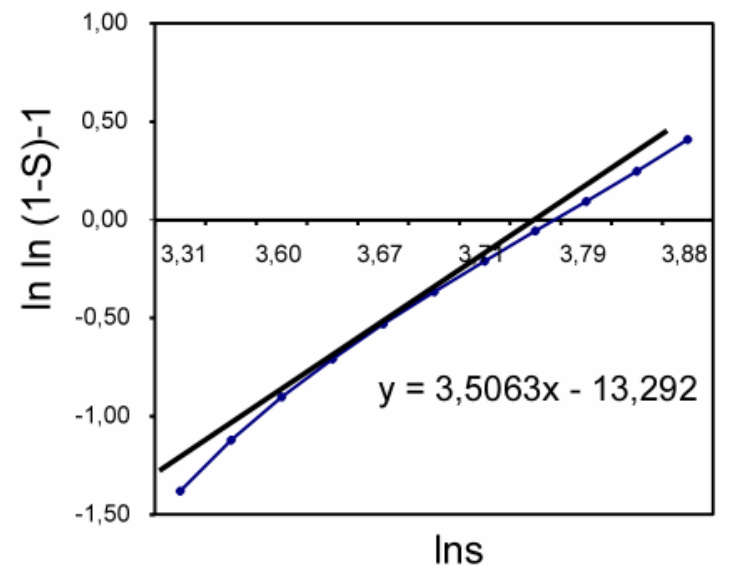

b)

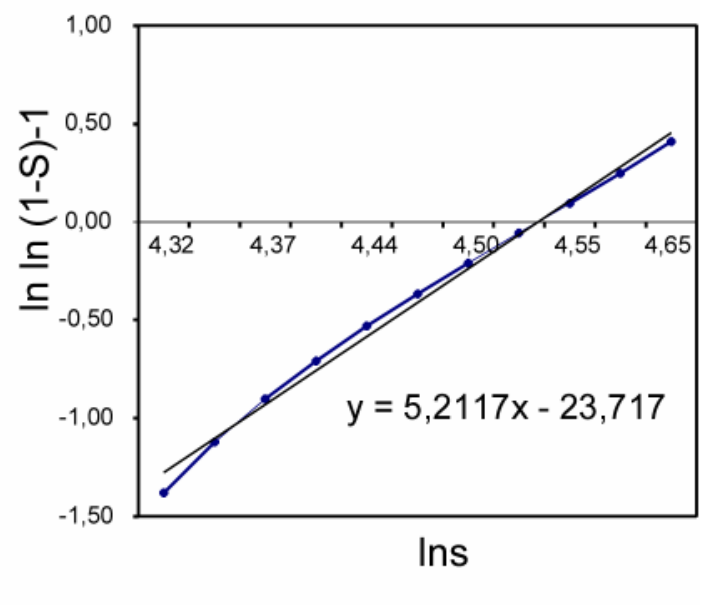

Figura 4.8 - Distribuição de Weilbull, a) corpos densos, b) corpos porosos e c) bicamada. 


\section{5 - Ensaio de Compressão}

Os corpos-de-prova ensaiados quanto a resistência a compressão tiveram as suas faces coladas em cilindros metálicos a fim de garantir o paralelismo entre as faces como mostra a Figura 4.9 e a Figura 4.10 ilustra o corpo-de-prova fraturado por compressão.

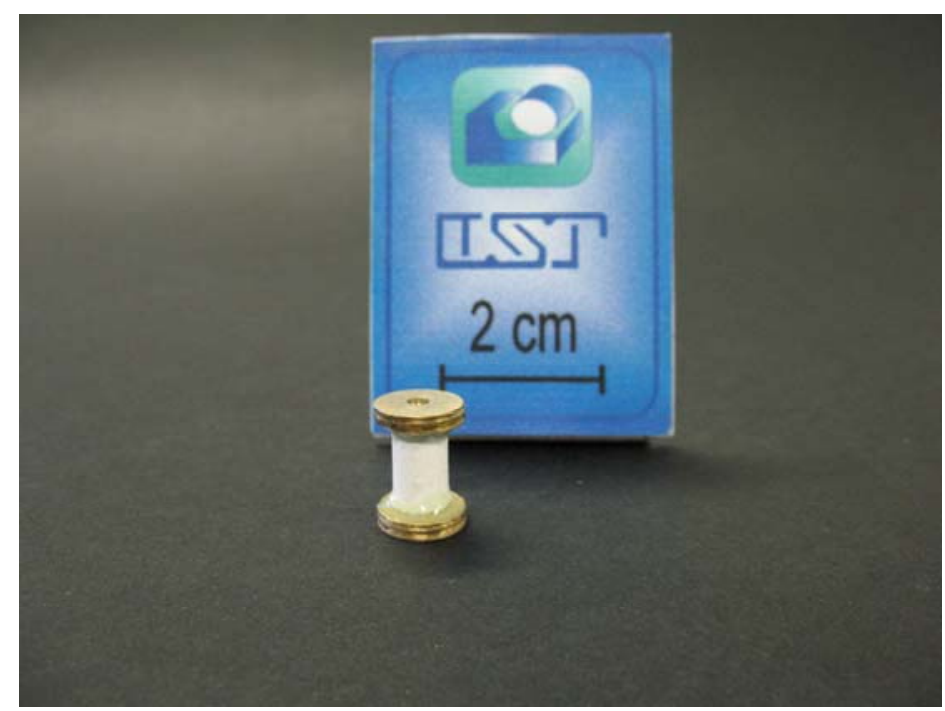

Figura 4.9 - Cilindro de escafolde para ensaio de compressão.

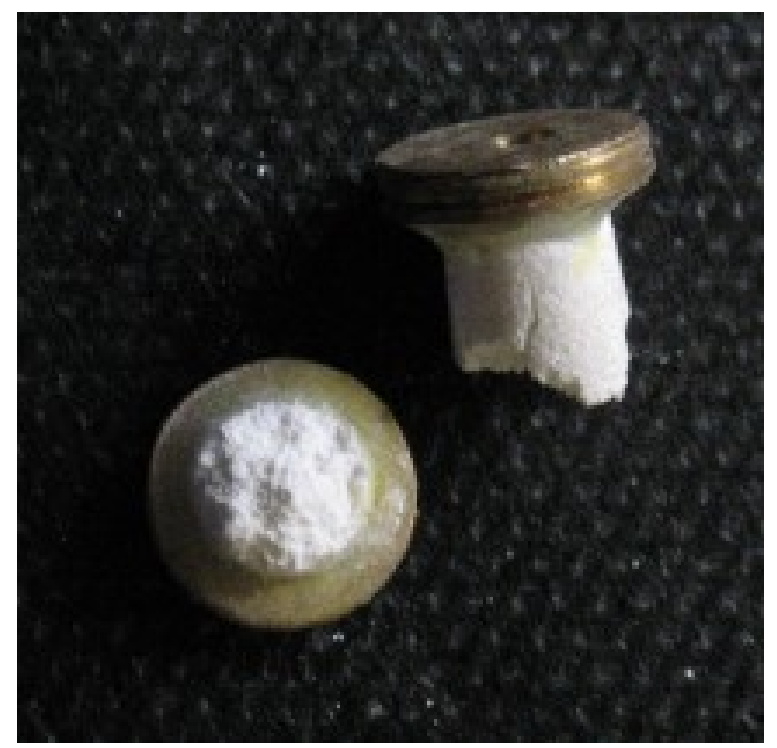

Figura 4.10 - Corpo-de-prova submetido a ensaio de compressão.

As Figuras 4.11, 4.12 e 4.13 ilustram os resultados dos ensaios de compressão dos escafoldes de alumina não impregnados, escafoldes de HA e escafoldes de alumina impregnados, respectivamente. 


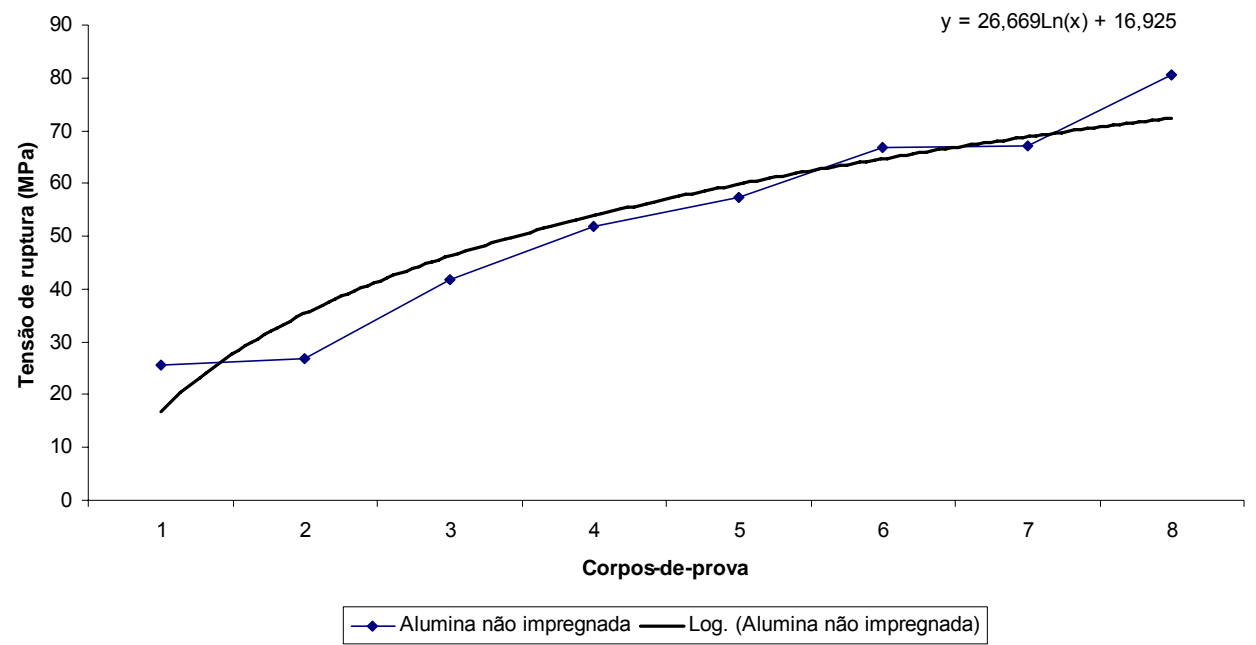

Figura 4.11 - Gráfico do ensaio de compressão dos escafoldes de alumina.

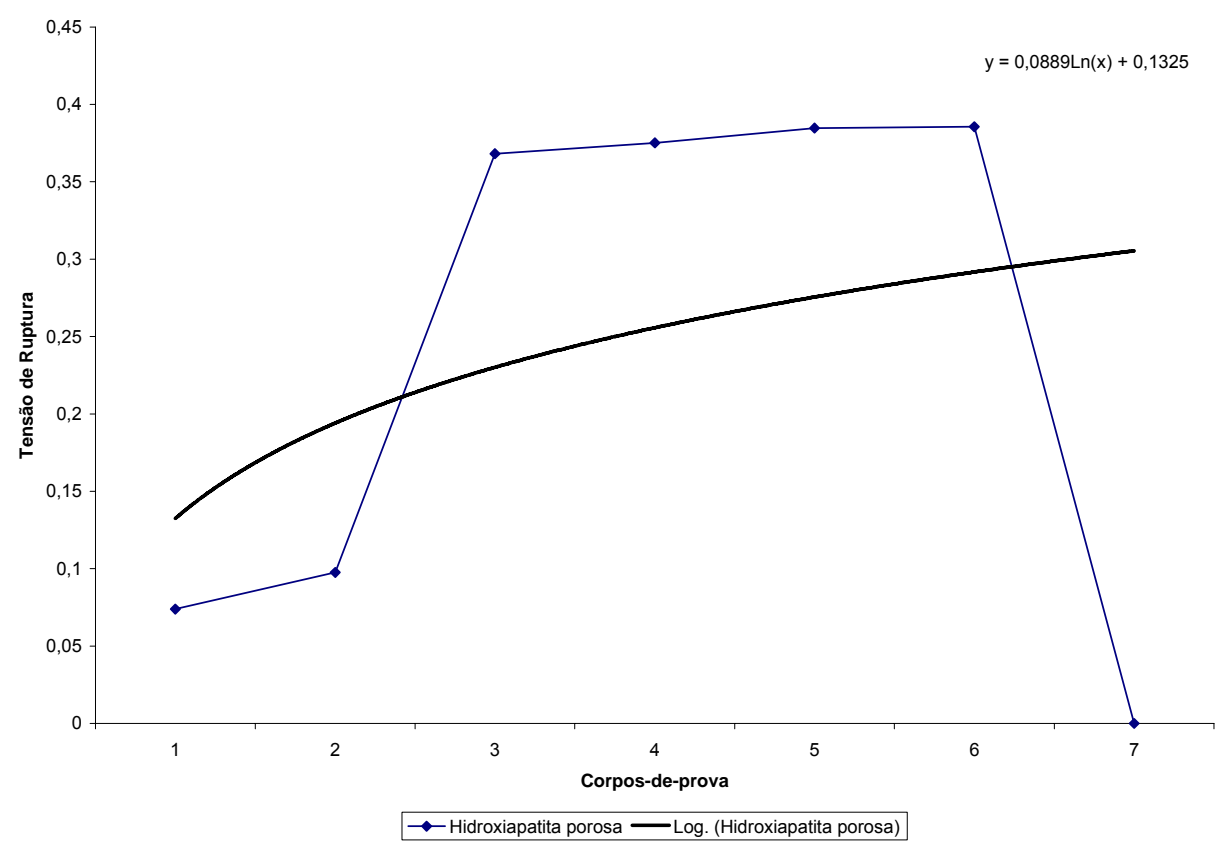

Figura 4.12 - Gráfico do ensaio de compressão dos escafoldes de hidroxiapatita. 


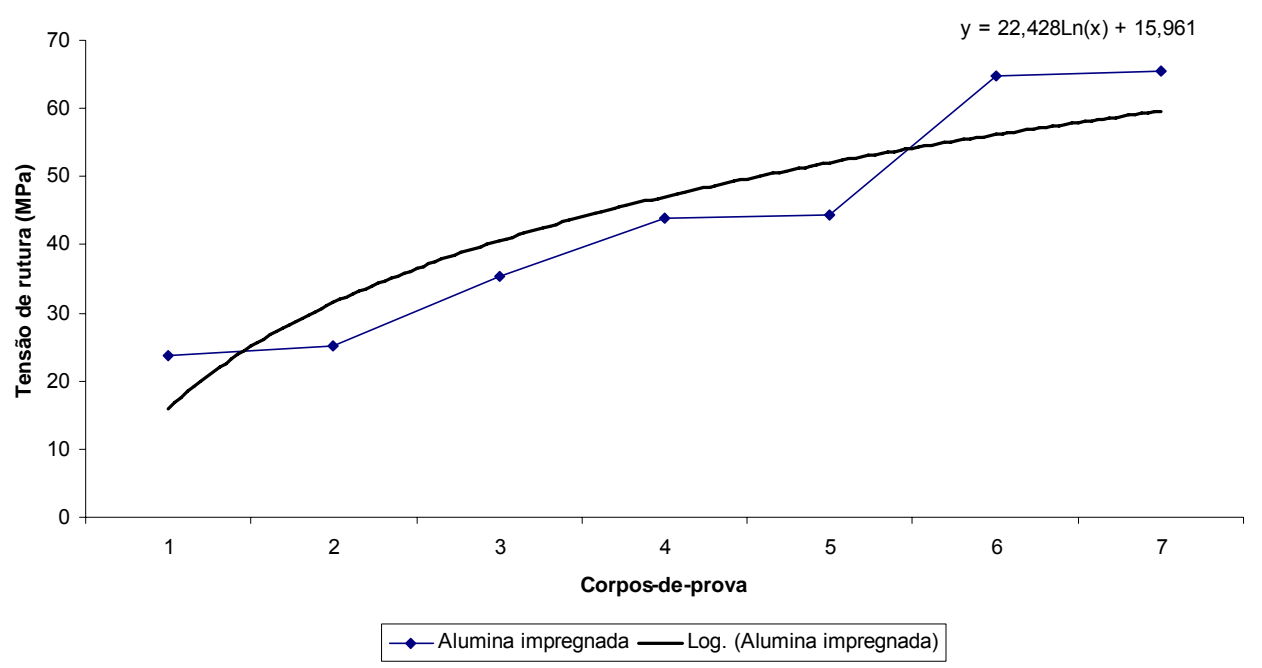

Figura 4.13 - Gráfico do ensaio de compressão dos escafoldes de alumina impregnada.

A média e desvio padrão dos resultados do ensaio de compressão então na Tabela 4.3.

Tabela 4.3- Valores da média e desvio padrão do ensaio de compressão.

\begin{tabular}{|l|c|c|}
\hline & Média (MPa) & Desvio Padrão $( \pm)$ \\
\hline Alumina porosa & 52,27 & 19,70 \\
\hline Hidroxiapatita poroso & 0,28 & 0,15 \\
\hline $\begin{array}{l}\text { Alumina impregnada } \\
\text { porosa }\end{array}$ & 43,27 & 16,94 \\
\hline
\end{tabular}

Os resultados indicam que a média da tensão de ruptura dos escafoldes de alumina impregnado com HA e biovidro caiu em relação aos escafolde de alumina pura, mas é bem superior ao escafolde de HA.

A queda de resistência dos escafoldes de alumina porosa impregnada deve-se provavelmente a concentração de tensão nas microtrincas devido a penetração do biovidro e da HA. Embora os valores apresentassem queda brusca na resistência mecânica, neste trabalho conseguiram-se valores maiores que os da literatura, se comparados com a pesquisa realizada por Liu e Miao (2005) com peças porosas de alumina que resultou nos seguintes valores $5,5-7,5 \mathrm{MPa}$. O tecido ósseo, segundo a literatura apresenta valores de resistência à compressão como segue: Reilly e Burstein (1975) encontraram 105 MPa em 
teste de compressão longitudinal e $131 \mathrm{MPa}$ em compressão transversal; Backaitis (1996) encontrou 170 MPa, Ravagliogli e Krajewski (1992) observaram que o fêmur humano resiste 125 a $166 \mathrm{MPa}$, Yang et al (2001) observaram para o osso compacto 130 a $180 \mathrm{MPa}$. Acredita-se que o método de manufatura pode ser ajustado para conseguir valores superiores de resistência à compressão, por exemplo, com a diminuição da porosidade total ou pelo uso da prensagem isostática a quente.

\section{6 - Análise por MEV}

Foram realizadas imagens em MEV dos corpos-de-prova fraturados. As Figuras 4.14 e 4.15 ilustram um dos corpos-de-prova fraturado onde se pode observar a transição da camada porosa para a camada densa, podendo-se verificar a integração consolidada entre as duas camadas cerâmicas.

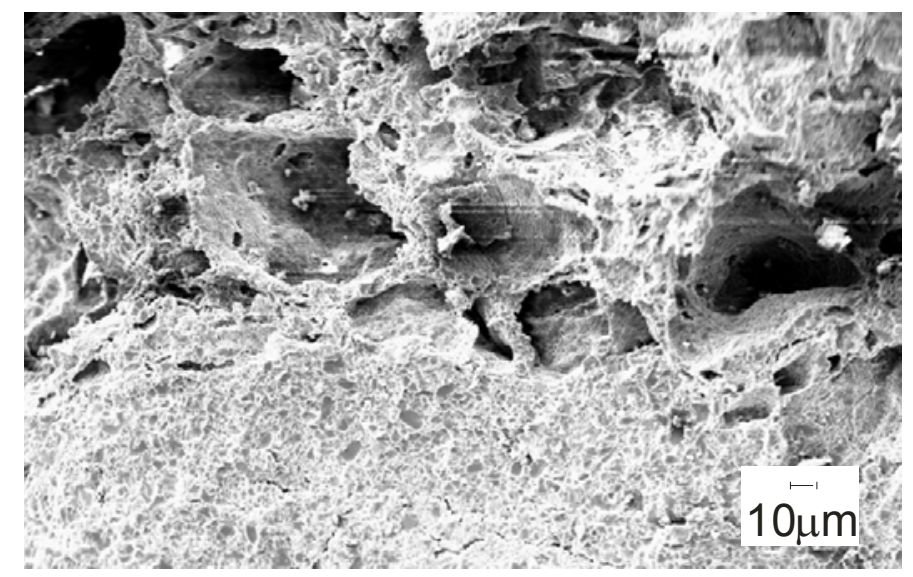

Figura 4.14 - Transição da camada densa com a porosa.

A Figura 4.15 ilustra um corte feito em um corpo-de-prova que foi submetido a polimento, sem agressão de tensão de fratura. Nesta figura, pode-se observar o tamanho e distribuição dos poros e nota-se também uma quantidade de pequenos poros inerentes ao processo de fabricação. Todos os cristais formadores de poros apresentavam tamanho 
mínimo de $74 \mu \mathrm{m}$. Os pequenos poros observados são decorrentes da possível fratura dos cristais durante a prensagem e também do impedimento da compactação plena devido aos cristais de dimensões muito superiores aos das partículas do pó cerâmico $(\sim 0,5 \mu \mathrm{m})$. $A$ pequena diferença entre a retração linear (Tabela 4.1) entre as duas camadas não ocasionou danos na interface.

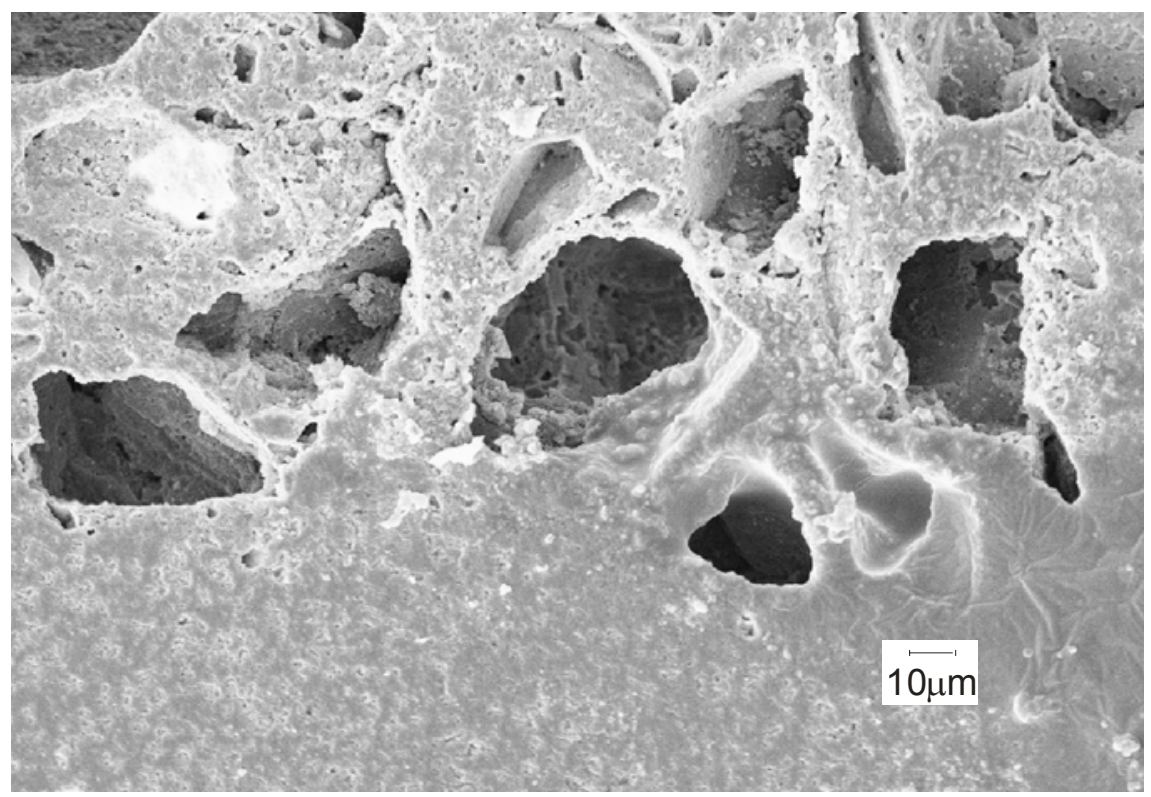

Figura 4.15 - Interface cortada e polida do corpo-de-prova.

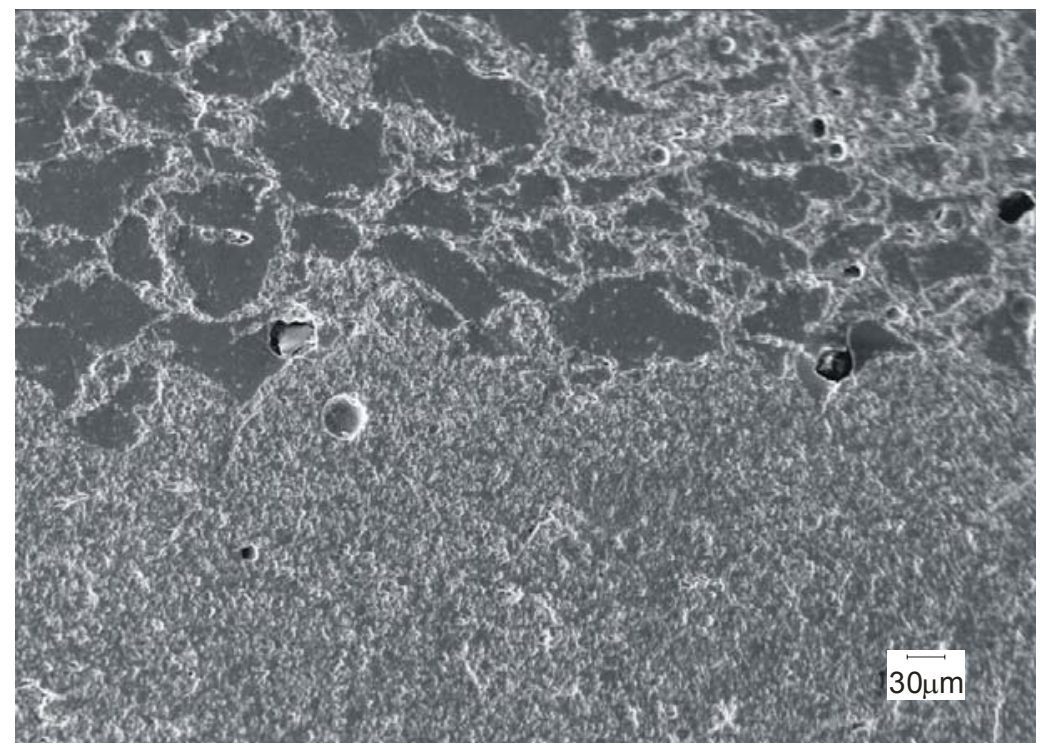

Figura 4.16 - Interface impregnada com resina, cortada e polida. 
A Figura 4.16 mostra a interface entre as camadas porosa e densa de um corpo-deprova impregnado por resina, lixado e polido.

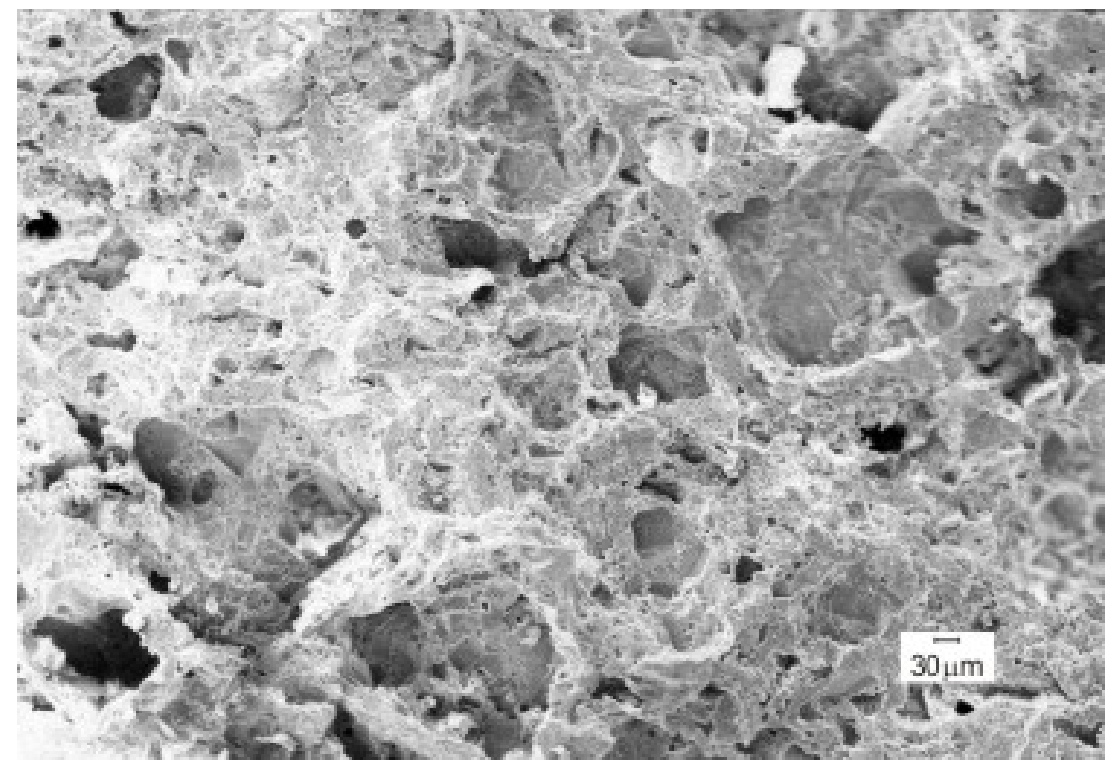

Figura 4.17 - Camada porosa formada por sacarose.

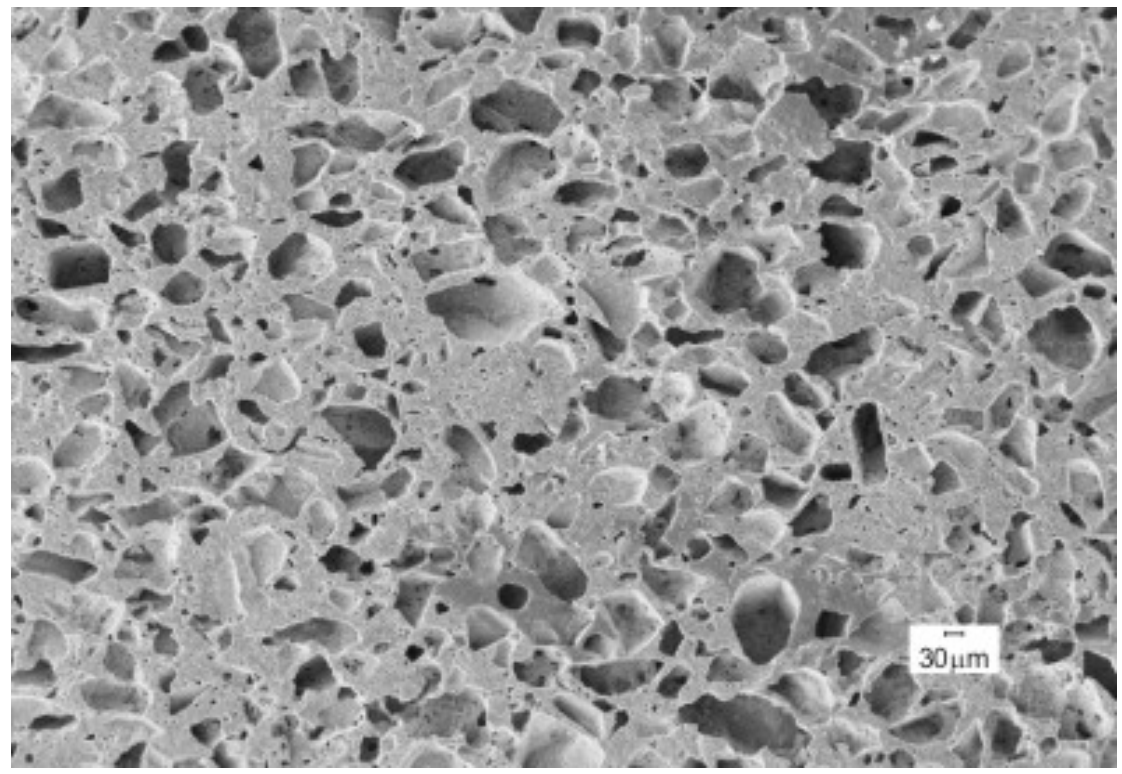

Figura 4.18 - Interface cortada e polida de corpo-de-prova poroso.

A Figura 4.17 ilustra a região fraturada de um corpo-de-prova poroso onde encontramos interconectividade entre os poros. A Figura 4.18 ilustra um corte do corpo de prova da camada porosa, este foi cortado em serra diamantada e sua superfície foi lixada e polida. Com análise superficial da imagem obteve-se tamanho médio dos poros em $(32 \pm 20$ 
$\mu \mathrm{m})$. Uma diminuição relativamente grande em relação ao tamanho das partículas de entrada de sacarose $(74$ a $177 \mu \mathrm{m})$.

\section{7 - Análise Química por EDX}

A análise realizada por EDX foi necessária para mostrar a eficiência do processo de infiltração e também para confirmar os elementos químicos contidos no biovidro utilizado nesta pesquisa.

A Figura 4.19 mostra o espectro de EDX de uma superfície de fratura do corpo-deprova de alumina infiltrada com biovidro/Hidroxiapatita. Observa-se na Figura 4.19, a presença de Oxigênio (50,65\%), Alumínio (34,20\%), Fósforo $(5,18 \%)$ e Cálcio $(9,97 \%)$, valores de percentual de elementos químicos presentes. Esta análise foi realizada próxima a superfície de impregnação e caracteriza-se qualitativamente apenas por mostrar que houve penetração do biovidro e HA, pois, os valores quantitativamente não são conclusivos.

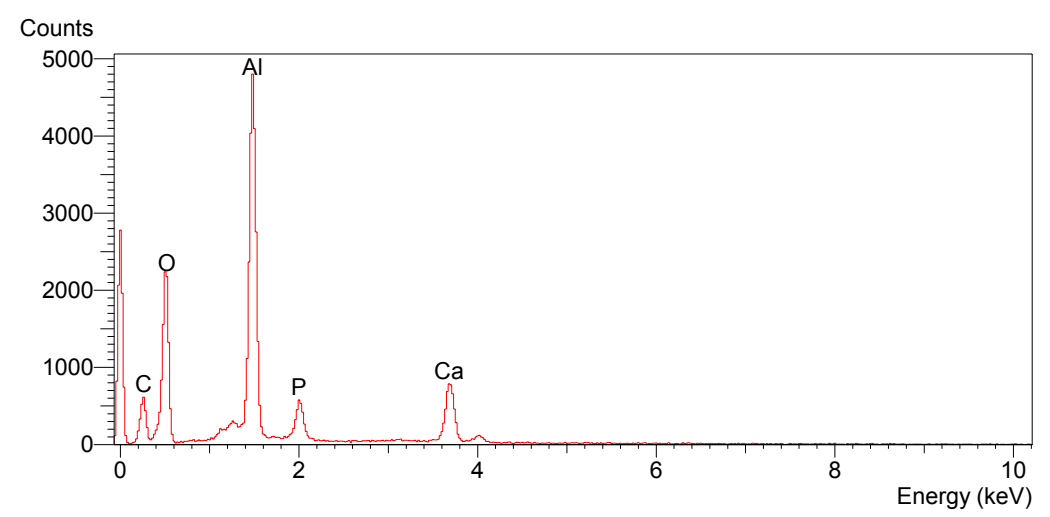

Figura 4.19 - EDX da alumina (Al2O3) infiltrada com hidroxiapatita-biovidro.

A Figura 4.20 mostra o mapeamento de EDX da amostra analisada. Nesta Figura verifica-se a presença de elementos exclusivos do biovidro e HA como o fósforo e o cálcio, numa profundidade de penetração de aproximadamente $100 \mu \mathrm{m}$. 


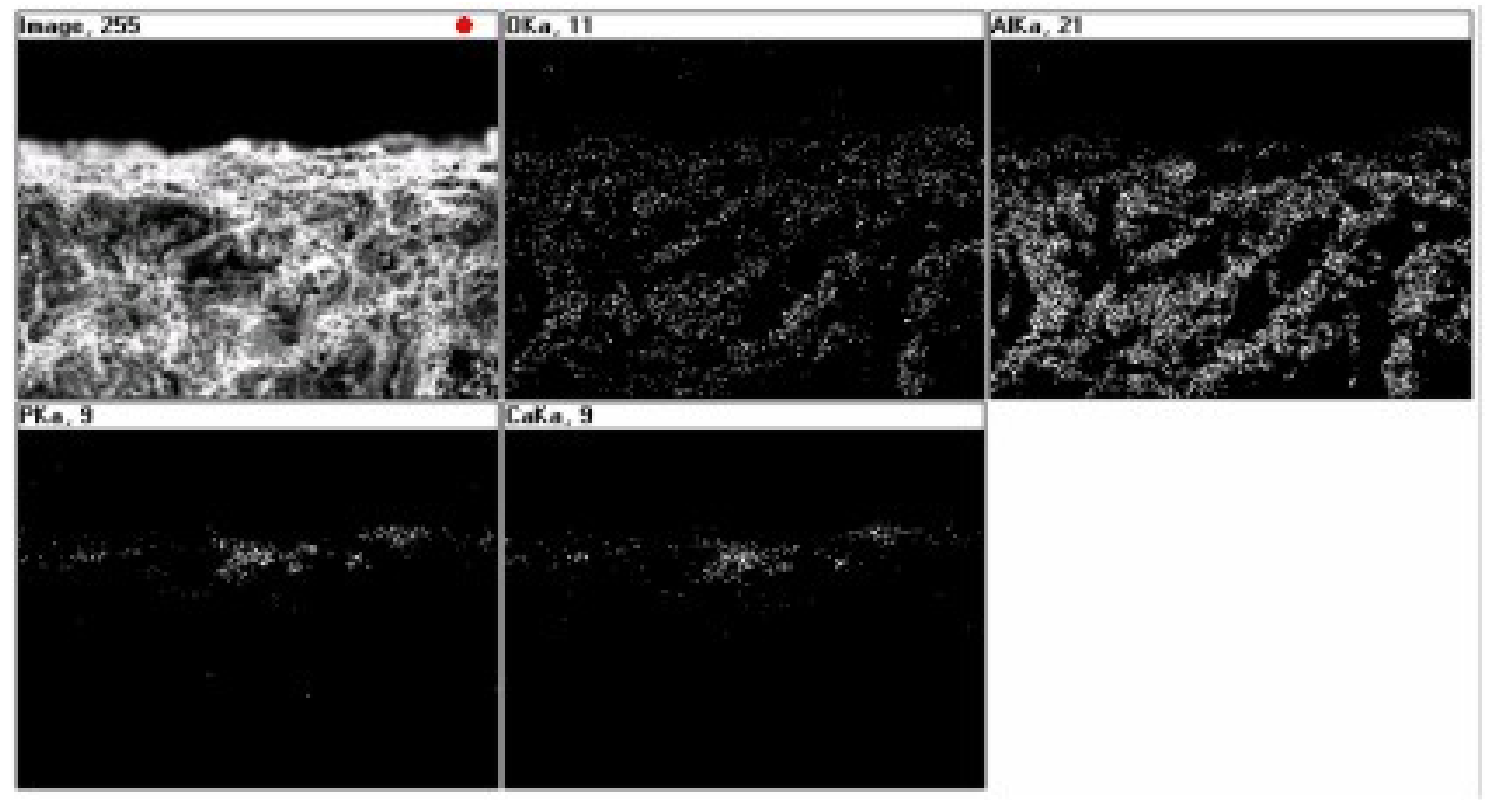

Figura 4.20 - O mapeamento de EDX nas amostras de alumina infiltrada por biovidro/hidroxiapatita.

$\mathrm{Na}$ figura 4.20 a profundidade de $100 \mu \mathrm{m}$ de infiltração revela uma limitação do processo empregado. Várias pode ser a origem dessa limitação, a mais provável talvez seja pela retenção seletiva de partícula no percurso de infiltração. Partículas de dimensões nanométricas sugerem resolver esta possível retenção. As pastilhas (escafoldes) de alumina após serem infiltradas por $\mathrm{HA}$ e biovidro foram aquecidas até à temperatura de $900^{\circ} \mathrm{C}$, embora a temperatura de fusão do biovidro seja aproximadamente de $1350^{\circ} \mathrm{C}$ foi aplicada uma temperatura menor para minimizar a difusão dos átomos de alumínio (Al) do suporte de alumina $\left(\mathrm{Al}_{2} \mathrm{O}_{3}\right)$ para o biovidro, fato esse indesejado, pois a presença de alumínio no biovidro acarretaria no aumento da durabilidade química desse. O termo durabilidade química é empregado para reportar que o biovidro perde a sua capacidade de osseointegração. 


\section{8 - Estudo de Caso (Implante Dentário)}

A Figura 4.21ilustra um implante dentário confeccionado pelo processo de colagem de barbotina em molde de gesso e a região porosa foi obtida através da imersão da peça em barbotina com agente porogênico, Figura 4.22 mostra um implante sem a camada porosa e a Figura 4.23 ilustra implantes com o pino escalonado.

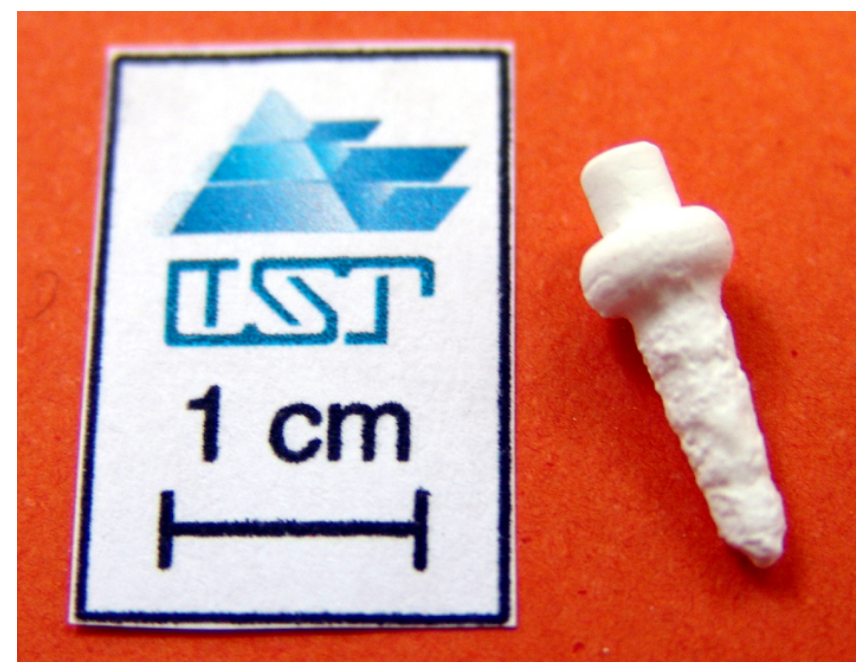

Figura 4.21 - Implante dentário com camada porosa.

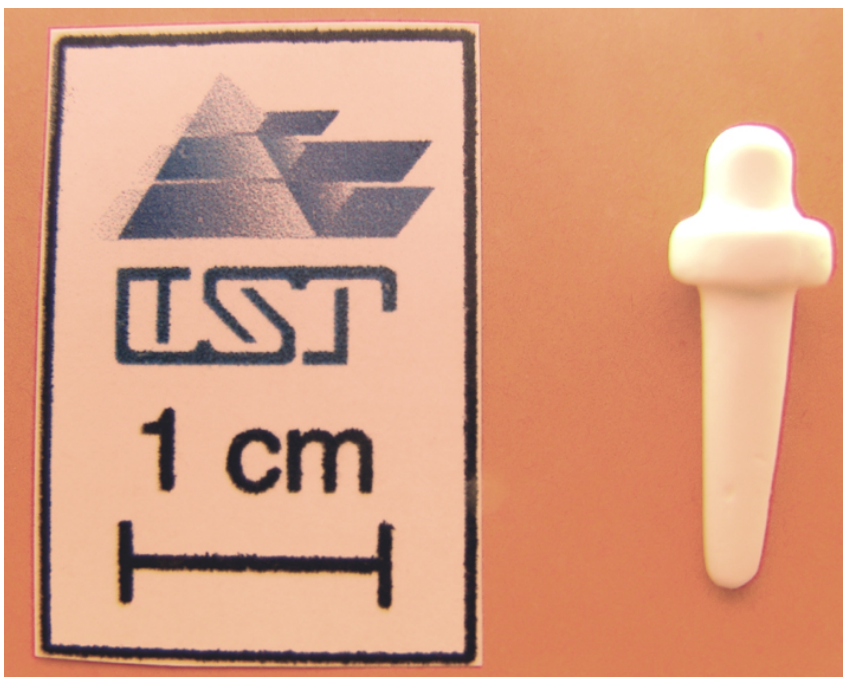

Figura 4.22 - Implante dentário sem camada porosa. 


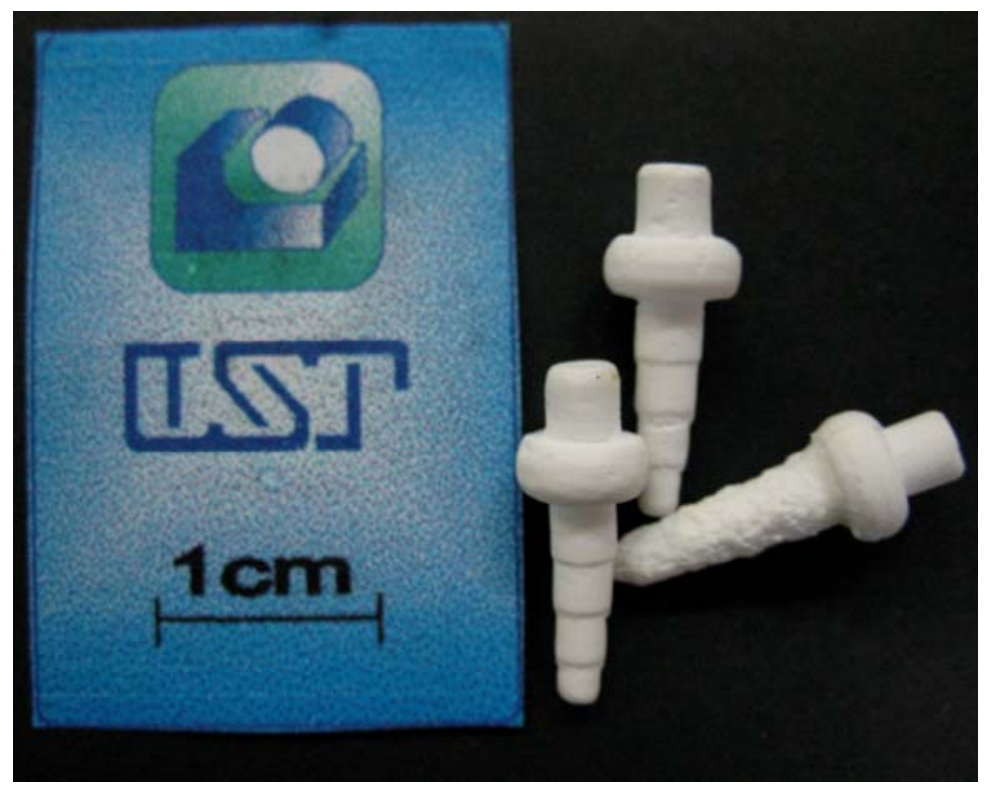

Figura 4.23 - Implantes com pino escalonado.

A Figura 4.24 ilustra um pino obtido por prensagem isostática e usinado a verde que servirá como matéria prima para a usinagem do implante dentário.

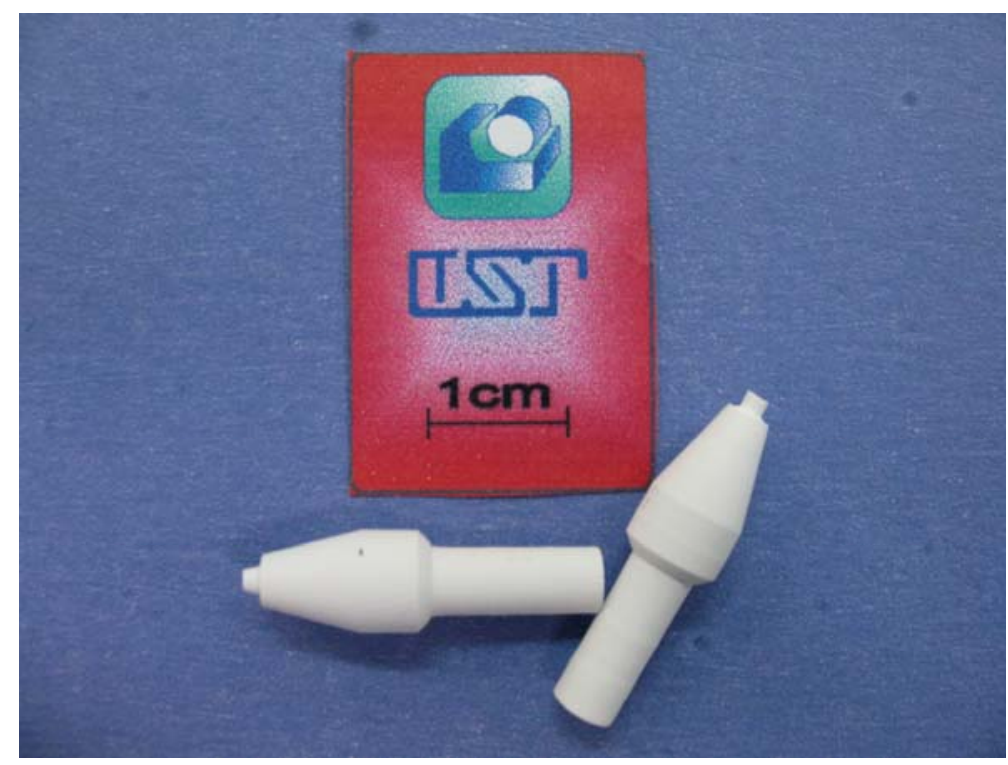

Figura 4.24 - Pinos prensados e usinados à verde. 


\section{9 - Estudo de Caso (Filtro Cerâmico de Dupla Camada)}

A Figura 4.25 ilustra os filtros cerâmicos de dupla camada confeccionada pela prensagem isostática com adição de sacarose como agente porogênico.

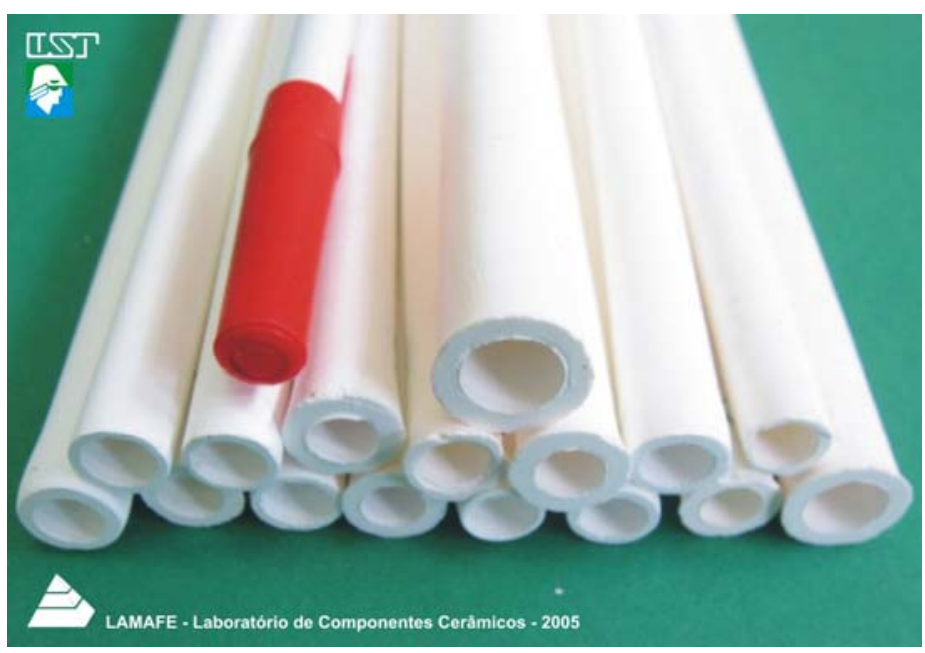

Figura 4.25 - Filtros cerâmicos de dupla camada.

As Figura 4.26, 4.27 e 4.28 mostram o MEV realizado no filtro cerâmico de dupla camada.

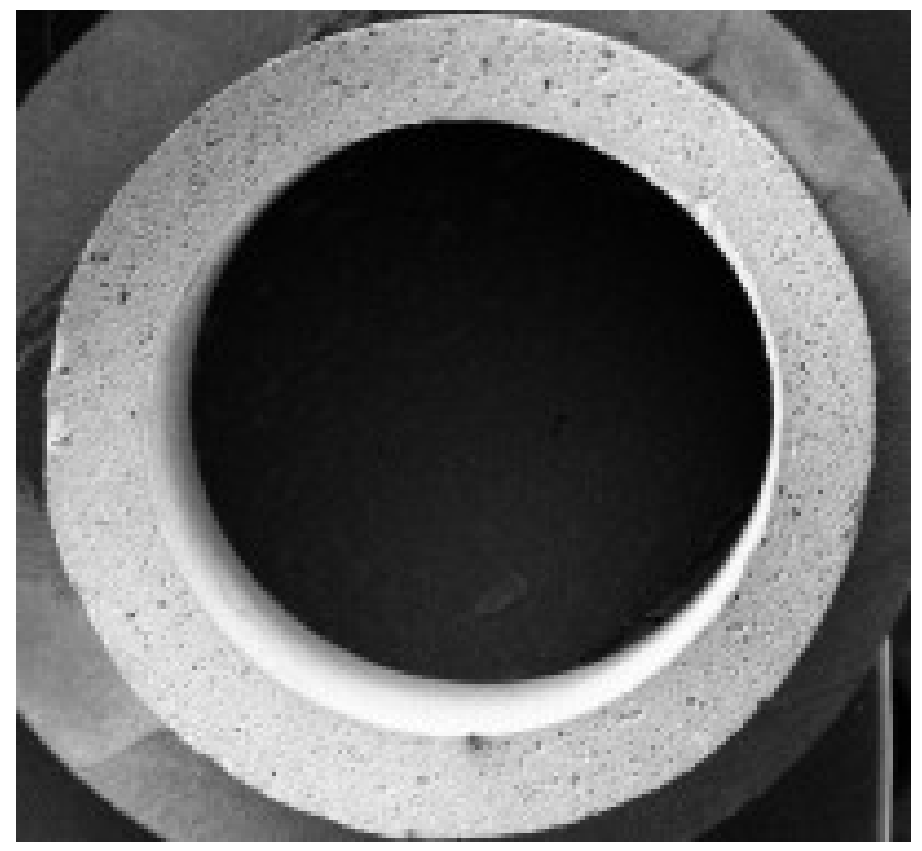

Figura 4.26 - MEV do filtro cerâmico de dupla camada com ampliação de 27X. 


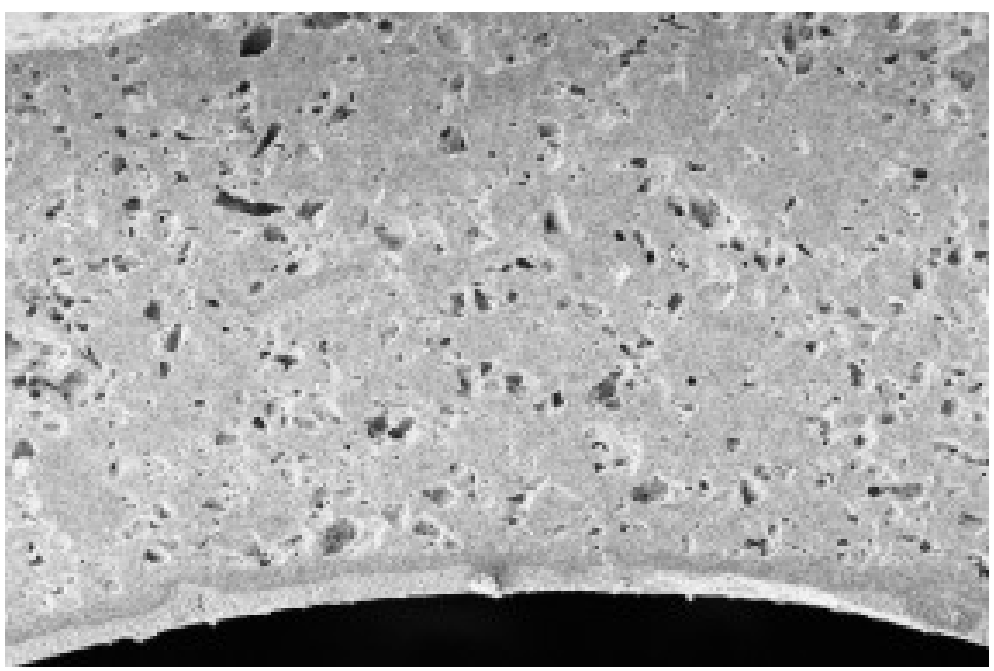

Figura 4.27 - MEV do filtro cerâmico de dupla camada com ampliação de 200X

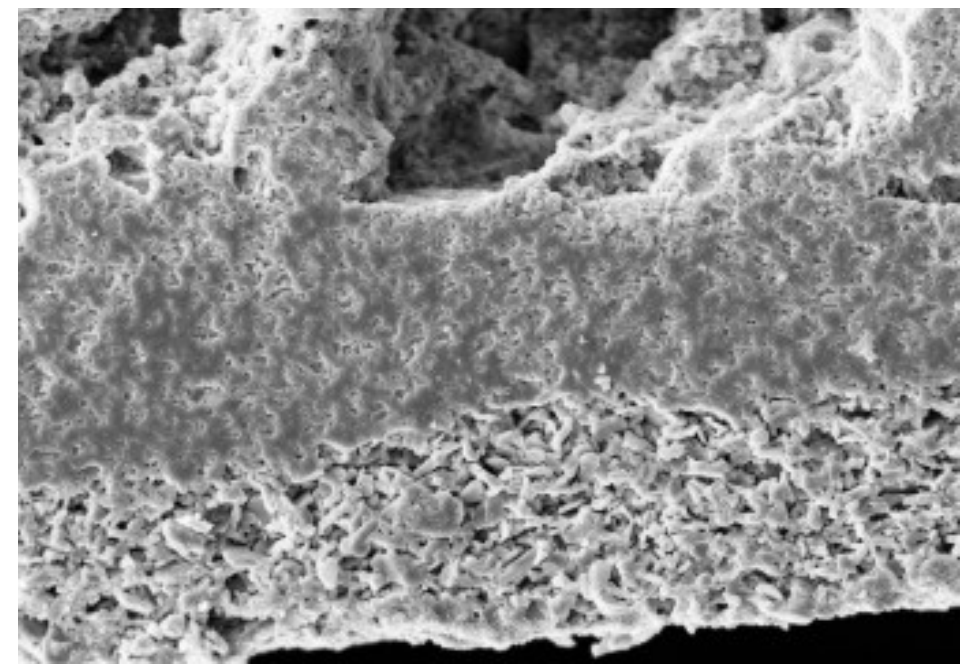

Figura 4.28 - MEV do filtro cerâmico de dupla camada com ampliação de $2000 \mathrm{X}$ 



\section{5 - CONCLUSÕES E RECOMENDAÇÕES}

Desenvolveu-se uma técnica de manufatura, baseada na co-prensagem isostática de pós com ou sem sacarose, seguida de lixiviação da sacarose, secagem e sinterização. Obteve-se com sucesso corpos com gradiente funcional, porém experimentos futuros podem melhorar o formato dos poros.

O método utilizado para infiltrar hidroxiapatita-biovidro nos escafoldes de alumina mostrou-se pouco eficiente e é necessário melhorar a técnica para manter o vácuo por mais tempo e também melhorar a viscosidade da barbotina de HA com biovidro para uma melhor penetração dessa barbotina nos poros da estrutura.

A análise termogravimétrica possibilitou a programação do forno que sinterizou os escafoldes sem deixar vestígios dos elementos orgânicos utilizados na preparação da barbotina, como foi observado na análise química por EDX.

A manufatura dos implantes exige mais experimentos de usinagem a verde e o molde de gesso para colagem de barbotina merece mais estudos para se melhorar a qualidade dos implantes.

O resultado obtido do uso do filtro cerâmico de dupla camada teve um bom desempenho e está registrado no artigo publicado por Fortulan et al (2005). 


\section{1 - Recomendações para Trabalhos Futuros}

O presente trabalho tratou do desenvolvimento de uma estrutura com material compósito com gradiente funcional, com a intenção de ser utilizada para a manufatura de implantes, verificou-se que durante o desenvolvimento do trabalho algumas considerações poderiam contribuir para a sua melhoria. Essas considerações seguem como recomendações para trabalhos futuros, a saber:

Utilizar outros tipos de agentes porogênicos com formato esférico ou oblongo para se verificar se ocorre uma melhora da estrutura do escafolde;

Realizar ensaios mecânicos com peças de vários tamanhos de poros e várias porcentagens de porosidade, assim como com diversas espessuras de camada porosa;

Desenvolver um material compósito com alumina e zircônia para a melhoria das propriedades mecânicas da estrutura;

Realizar experimentos in vivo para análise da eficiência da estrutura desenvolvida. 
6 - REFERÊNCIAS BIBLIOGRÁFICAS

AKIN, J. E. The generation of elements with singularities. International Journal for Numerical Methods in Engineering. 1976, No. 6, vol. 10, pp. 1249-1260.

ALMEIDA, F. A.; MELO, F. C. L.; THIM, G. P. Obtenção de cerâmica porosa a partir da técnica de conformação direta com amido comercial. Disponível em: <http://www.bibl.ita.br/viiiencita/Obtencoo\%20de\%20ceramica\%20porosa.pdf> Acessado em: 14 novembro 2005.

ANDRADE, A. L.; DOMINGUES, R. Z. Cerâmicas Bioativas - Estado da Arte. Química Nova, 2006, vol. 29, n. 1, pp. 100-104.

ASTM C 1161 - 90. Standard test method for flexural strength of adavanced ceramics at ambiente temperature. American Society for Testing and Materials, 1991, 7p.

BACKAITIS S. H. (Editor). Biomechanics of impact injury and injury tolerances of the extremities. Ed. SAE International. Publicado pela Society of automotive engineering, 1996, p. 254.

BARBUCCI, R. Integrated Biomaterial Science. New York, Kluwer Academic Publishers. Jan. 2002, 1037p., ISBN: 0306466783.

BATCHELOR, A. W. Service Characteristics of Biomedical Materials and Implants. Biomaterials end Bioengineering, 2004, vol. 3, 183 p. 
BEAL, V. E. Fabricação de gradientes funcionais entre aço ferramenta e cobre por fusão seletiva a laser usando um feixe de laser pulsado Nd:YAG de alta potência para aplicação em moldes de injeção. Florianópolis, Universidade de Santa Catarina, 2005, 232 p.

BINNER. J.; SAMBROOK R. Ceramic Foams - Processing and application as filters, interpenetrating composites and biomedical materials. Disponível em: <www.azom.com/details.asp?ArticlelD=1869> Acessado em: 14 novembro de 2005.

BORUSZEWSKI, W.; TORTAMANO NETO, P.; SAITO, T. Stress distributions in mandibles around osseo-integrated implants, according to the occlusionpattern, using MSCINASTRAN three-dimensionalmodeling. Disponível em: <www.mscsoftware.com/support/library/conf/wuc96/04b_boru.pdf>. Acesso em: 23 setembro 2005.

BOSE, S. et al. Processing and characterization of porous alumina scaffolds. Journal of materials science: materials in medicine, 2002 , vol. 13, pp. 23-28.

BOSE, S.; Darsell, J.; Kintner, M.; Hosick, H.; Bandyopadhyay, A. Pore size and pore volume effects on alumina and TCP ceramic scaffolds Materials Science and Engineering, 2003, 23(4), pp.479-486.

BROVARONE, C. V.; VERNÉ, E.; APPENDINO, P. Macroporous bioactive glass-ceramic scaffolds for tissue engineering. J Mater Sci: Mater Med, 2006, vol 17, pp. 1069-1078.

CAMILO, C. C. Escafoldes para implantes ósseos em alumina/hidroxiapatita/biovidro: análise mecânica e in vitro. Dissertação (Mestrado) - Escola de Engenharia de São Carlos, USP, 2006, 120p.

CAMPBELL, A. A. Bioceramics for implant coatings. Materialstoday, 2003, pp. 26-30, ISSN 1369-7021.

CAMPOS, S. D.; de CAMPOS, É. A.; SILVEIRA, C. B.; BINI, R. A. Biomaterials based on Na2O-CaO-SiO2-P2O5 prepared with sawdust or corn glucose: effects on porosity and crystallinity. Cerâmica, July/Sept. 2005, no.319, vol.51, pp.274-279, ISSN 0366-6913.

CANNILLO, V.; MANFREDINI, T.; SILIGARDI, C.; SOLA, A. Preparation and experimental characterization of glass-alumina functionally graded materials. Journal of the European Ceramic Society. 2006, 26 (6), pp.993-1001. 
CANNILLO, V.; MONTORSI, M.; SILIGARDI, C.; SOLA, A.; de PORTU, G.; MICELE, L.; PEZZOTI, G. Microscale computational simulation and experimental measurement of thermal residual stresses in glass-alumina functionally graded materials. Journal of the European Ceramic Society. 2006, 26 (8), pp.1411-1419.

CHU, C.; ZHU, J.; YIN, Z.; LIN, P. Structure optimization and properties of hydroxyapatite-Ti symmetrical functionally graded biomaterial. Materials Science and Engineering, 2001, pp. 205-210.

DACULSI, G.; PASSUTI, N. Effect of the macroporosity for osseous substitution of calcium phosphate ceramics. Biomaterials, 1990, vol.11, pp. 86-87.

FINISIE, M. R.; JOSUE, A.; FAVERE, V. T.; LARANJEIRA, M. C. M. Synthesis of calciumphosphate and chitosan bioceramics for bone regeneration. An. Acad. Bras. Ciênc., Dec. 2001, no.4, vol.73, pp.525-532. ISSN 0001-3765.

Five Year Plan: Multy-Agency Tissue Engineering Science (MATES) Work. Disponível em: <www.tissueengineering.gov/5yearplan.htm > Acesso em: 05 fevereiro 2006.

FORTULAN, C. A. Desempenho das cerâmicas estruturais associado aos métodos de conformação por injeção, prensagem isostática e projetos de equipamentos e moldes. Tese (Doutorado) - Escola de Engenharia de São Carlos, USP, São Carlos, 1997.

FORTULAN, C. A. Compósito alumina-zircônia: obtenção através de conformação coloidal e caracterização microestrutural. Relatório de Pós-doutorado - Universidade Federal de São Carlos, São Carlos, Mar.1999, 82p.

FORTULAN, C. A.; FONTES, S. R.; IKEGAMI, R. A., Purquerio, B. M. Manufatura de membranas cerâmicas tubulares bicamadas por prensagem hidrostática. In: Congresso Brasileiro de Cerâmica, 2005, São Pedro - S.P. (junho). Anais do 49o Congresso Brasileiro de Cerâmica - ABCeram (no prelo, junho 2005). São Pedro - S.P. : Associação Brasileira de Cerâmica, 2005.

GAZZIRO, M. A. et al Controle de Precisão de micro-motores para realização de implante dentário osseointegrado. III CLAEB, 2004.

GOMIDE, V. S.; ZAVAGLIA C. A. C. Estudo da porosidade do compósito zircônia hidroxiapatita através da análise por MEV para aplicação em implante 
craniomaxilofacial. III Congresso Latino Americano de órgãos artificiais e biomateriais. Campinas - Brasil. 27 a 30 de julho de 2004.

GOUPEE, A. J.; VEL, S. S. Two-Dimensional optimization of material composition of functionally graded materials using meshless analyses and a genetic algorithm. Comput. Methods Appl. Mech. Engrg, 2006, vol.195, pp. 5926-5948.

HAHN, J. One-Piece Root-Form Implants: A Return to Simplicity. Journal of Oral Implantology. 2005, No. 2, vol. 31, pp. 77-84.

HEINEKEN, F. G.; SKALAK, R. Tissue Engineering: A Brief Overview, Journal of Biomechanical Engineering, 1991, 111 p.

HELLMAN, K. B.; KNIGHT, E.; DURFOR, C.N. Tissue Engineering: Product Applications and Regulatory Issues, pp. 341-366, Frontiers in Tissue Engineering, Charles W. Patrick, Antonio G. Mikos, and Larry V. McIntire (eds.), Amsterdam, Elsevier Science (1998).

HELLMAN, K. B.; SOLOMON, R. R.; GAFFEY, C.; DURFOR, C.; BISHOP, J. G. III. Tissue Engineering: Regulatory Considerations, Principles of Tissue Engineering, 2nd Edition, Robert Lanza, Robert Langer, and Joseph P. Vacanti (eds.), Academic Press, San Diego, California (in press).

$\mathrm{HENCH}$, L. L.; et al. An investigation of bonding mechanisms at the interface of a prosthetic material. University of Florida, 1974, pp. 24-117.

HENCH, L. L.; ETHRIDGE, E. C. In Biomaterials: an interfacial approach; Noordergraaf, A., Ed.; Academic Press; New York, 1982, p. 3.

HENCH, L. L.; WILSON, J. Introduction to bioceramics. Singapore. Word Scientific Publishing Co. Pte. Ltd. 1993, Cap. 4-6.

HOLLISTER, S. J. et al Engeneering craniofacial scaffolds. Orthod Craniofacial Res 8, 2005, pp.162-173.

HULBERT, S. F.; COOKE, F. W. J. Biomedical Materials Research. Symp.1970, vol. 4, Issue 1.

HULBERT, S. F.; et al. In Ceramics in severe environments. Ed. W. W. Kriegel \& H. Palmour, Palmour, Plenum Press, New York. 1971, 417 p. 
HULBERT, S. F.; HENCH, L.L.; FORBERS, D.; BOWMAN, L. S. History of Bioceramics. Ceramics International, 1982, vol. 8, n.4, pp. 131-140.

HULBERT, S. F.; et al. Ceramics in clinical application: past, present and future. Elsevier, Amsterdam, The Netherlands, 1987, pp. 189-213.

IKADA, Y. Biological Materials. In: BARBUCCI, R. Integrated Biomaterials Science. Hingman, MA, USA: Kluwer Academic Publisher, 2002. p2. Disponível em <http://site.ebrary.com/lib/usp/Doc?id=10053355\&ppg=33>. Acessado em: 14 março 2005.

IKEGAMI, R. A.; CAMILO, C. C.; MONARETTI, F. H.; FORTULAN, C. A.; PURQUERIO, B. DE M. Reforço em corpo cerâmico poroso de alumina com adição de camada densa. In: CONGRESSO BRASILEIRO DE CERÂMICA (49.: 2005: São Pedro). Anais São Pedro, 2005, pp.1-10.

IPEN Avanços na área de biomateriais beneficiam população. Disponível em <http://ipen.br/cctm/news-e.html>. Acessado em: 23 abril 2005.

JONES, J. R. Observing cell response to biomaterials. Materials Today, dezembro 2006, vol. 9, n 12, pp. 34-43, ISSN 13697021.

KARAGEORGIOU, V.; KAPLAN, D. Porosity of 3D biomaterial scaffolds and osteogenesis. Biomaterials, 2005, pp. 5474-5491.

KAWACHI, E. Y.; BERTRAN, C. A.; REIS, R. R.; ALVES, O. L. Biocerâmicas: Tendências e perspectivas de uma área interdisciplinar. QUIMICA NOVA, 2000, pp. 518-522.

KAWASAKI, A.; WATANABE, R. Concept and P/M Fabrication of Functionally Gradient Material. Ceramics International, 1995, pp. 73-83.

KIEBACK, B.; NEUBRAND, A.; RIEDEL, H. Processing Techniques for Funcionally Graded Material. Material Science and Engineering, 2003, pp. 81-105.

KLAWITTER, J. J. et al. An evaluation of bone growth into porous high density polyethylene. Journal of biomedical Materials. Research, 1976, vol. 10, pp. 311-321.

KOIZUMI, M. FGM Activities in Japan. Ryukoku University, Ohtsu, Japan, 1996, 4p. 
LAYROLLE, P.; ITO, A.; TATEISHI, T. Sol-Gel synthesis of amorphous calcium phosphate and sintering into microporous hydroxyapatite bioceramics. Journal of the American Ceramic Society, 1998, n.6, vol. 81, pp. 1421-28.

LANGE, F. L. Powder processing science and technology for increased reliability. Journal of American Ceramic Society, 1989, n.1, vol.72, pp.3-15.

LE HUEC, J. C.; et al. Influence of porosity on the mechanical resistance of hydroxyapatite ceramics under compressive stress. Biomaterials. 1995, vol. 16, pp. 113118.

LEE, E. J., KIM, H. E. Production of hydroxyapatite/bioactive glass biomedical composites by the hot-pressing technique. J. Am. Cera. Soc., 2006, vol. 89, n 21, pp. 3593-3596.

LEE et al. Patente No.: US 6,544,290 B1. Apr. 2003.

LIU , D. M. Influence of porosity and pore size on the compressive strength of porous hydroxyapatite ceramic. Ceramics internacional, 1997, vol. 23, pp. 135-139.

LIU, J.; MIAO, X. Porous alumina ceramics prepared by slurry infiltration of expanded polystyrene beads. Journal of materials science, 2005, vol. 40, pp.6145-6150.

LYSAGHT, M.J.; NGUY, N. A. P.; SULLIVAN, K. An Economic Survey of the Emerging Tissue Engineering Industry, Tissue Engineering, 1998, vol.4, pp. 231-238, Issue 3.

LYSAGHT, M. J.; REYES, J. The Growth of Tissue Engineering. Tissue Engineering, 2001, vol.7, pp.485-493, Issue 5.

MA, J.; TAN, G. E. B. Processing and characterization of metal-ceramics functionally gradient materials. Journal of Materials Processing Technology, 15 J une 2001, vol. 113, pp. 446-449, Issue 1-3.

MACEDO, N. L. et al Bone defect regeneration with bioactiveglass implantation in rats. Journal of Applied Oral Science, 2004, vol. 12, n 2, pp. 137-143.

MARX, R.E.; SAUNDERS, T.R. Reconstruction and rehabilitation of cancer patients. In: FONSECA, R.J.; DAVIS, W.H. Reconstructive preprosthetic oral and maxillofac. Surgery. Philadelphia, saunders, 1986, pp.347-428. 
MASTERS, D.H. Implants. Bone and bone substitutes. Calif. dent. Ass. J., 1988, vol.16, n.1,pp. 56-65.

Materials Foresight Priority topics for future biomaterials developments. Disponível em: <http://www.iom3.org/foresight/Biomaterials\%20web.pdf> Acessado em: 02 julho 2006.

MATSUNO et al. Sintering of zirconia coated hydroxyapatite particles. Journal of the Ceramic Society of Japan, 1996, vol. 104, pp.942-945.

MIYAMOTO, Y. et al Functionally Graded Materials: Design, Processing and Applications. Materials Technology Series, 1999, 330 p., ISBN 0412607603.

MONARETTI F. H. Estudo de viabilização de método e técnicas de manufatura de corpos porosos estruturais para engenharia de tecidos. Dissertação (Mestrado) - Escola de Engenharia de São Carlos, USP, 2005, 92p.

MONARETTI, F. H (a); CAMILO, C. C; IKEGAMI, R A; FORTULAN, C. A; PURQUERIO, B. DE M. Fabricação de corpo poroso estrutural cerâmico aplicável à engenharia de tecidos. In: CONGRESSO BRASILEIRO DE CERÂMICA (49: 2005: São Pedro). Anais São Pedro, 2005, pp. 1-12.

MONARETTI, F. H (b); CAMILO, C. C; IKEGAMI, R A; FORTULAN, C. A; PURQUERIO, B. $D E M$. Manufacture of ceramic scaffolds for tissue engineering using cane sugar as pore-forming agent. In: FIFTH INTERNATIONAL LATIN-AMERICAN CONFERENCE ON POWDER TECHNOLOGY (50: 2005: Costa do Sauípe). Anais, 2005, p. 6.

NIEDERAUER, G. G.; McGEE, T. D. Evaluation of a bioactive ceramic composite as a dental implant. Ceramic Bulletin, 1991, vol. 70, n 6, pp.1010-1015.

OHTSUKI, C.; MIYAZAKI, T.; KAMITAKAHARA, M.; TANIHARA, M. Design of novel bioactive material through organic modification of calcium silicate. Journal of the European Ceramic Society, 2007, vol.27, pp. 1527-1533.

ORTEGA, F. S.; PAIVA, A. E. M.; RODRIGUES, J. A.; PANDOLFELLY, V. C. Propriedades mecânicas de espumas cerâmicas produzidas via "geocasting". Cerâmica, 2003, vol. 49, pp. 1-5.

PARK, J. B. Biomaterials: an introduction. New York, Plenum Press, 1979, 251p. 
PEREIRA, A. P.V.; VASCONCELOS, W. L.; ORÉFICE, R. L. Novos Biomateriais: Orgânico-Inorgânicos Bioativos. Polímeros: Ciência e Tecnologia, 1999, pp. 104-109.

PINTO, A. K.; XAVIER, J. A. N. Manutenção: Função Estratégica. Rio de Janeiro: Qualitymark Ed., 2001, 341p. ISBN 85-7303-323-1.

RAMAKRISHNA, S.; MAYER J.; WINTERMANTEL, E.; LEONG, K. W. Biomedical applications of polymer-composite materials: a review. Composite Science and Technology, 2001, vol.61, pp. 1189-1224.

RAVAGLIOLI A.; KRAJEWSKI A. Bioceramics: Materials, properties, applications. London: Chapman \& Hall, 1992, 416 p. ISBN 0-412-34960-4.

REDDI, A. H. Bioceramics, cells and signals in tissue engineering. Bioceramics, Nov.1998, vol. 11, pp.9-11.

REILLY D.T., BURSTEIN A.H. The elastic and ultimate properties of compact bone tissue. J. Biomech, 1975, Vol. 8, pp. 393-405.

REYES, L. C. V. Aplicação de um vidro bioativo em tíbias de coelhos. São Carlos. Interunidades Bioengenharia. Universidade Estadual de São Paulo, 2000. 91p. Dissertação (Mestrado).

RODRIGUES, C. V. M.; et al Characterization of a bone collagen-hydroxyapatite composite scaffold for bone tissue engineering. Biomaterials, 2003, vol. 24, pp. 49874997.

ROSA, D. S.; SALVINI, V. R.; PANDOLFELLI, V. C. Processamento e avaliação das propriedades de tubos cerâmicos porosos para microfiltração de emulsões. Cerâmica, 2006, vol. 52, n 322, pp. 167-171, ISSN 0366-6913.

ROSSI, A. M.; TERRA, J.; MAVROPOULOS, E.; MOREIRA, E. L. A ciência e tecnologia das biocerâmicas. Disponível em: <www.cbpf.br/RevistaCBPF/pdf/BioMat.pdf>. Acessado em: 16 de novembro de 2005.

RYAN, G.; PANDIT, A.; APATSIDIS, D. P. Fabrication methods of porous metals for use in orthopaedic applications. Biomaterials, 2006, vol.27, Issue 13, pp. 2651-2670. 
SACHLOS, E.; CZERNUSZKA, J. T. Making Tissue Engineering Scaffolds Work. Review on the Application of Solid Freeform Fabrication Technology to the Production of Tissue Engineering Scaffolds. European Cells and Materials, 2003, vol. 5, pp. 29-40.

SANTOS, L. A., Desenvolvimento de Cimento de Fosfato de Cálcio Reforçado por Fibras para uso na Área Médico-Odontológica, Campinas, Faculdade de Engenharia Mecânica, Universidade Estadual de Campinas, 2002. 249 p. Tese Doutorado.

SEPULVEDA, P.; PANDOLFELLI, V. C.; ROGERO, S. O. Porous hydroxyapatite prepared by gelcating of foams for biomedical applications. Cerâmica, Nov./Dec. 1999, vol.45, no.296, pp.198-202. ISSN 0366-6913.

SILVA, G. Metodologia para o estudo de influência das condições de retificação na resistência mecânica à flexão de cerâmicas policristalinas de Al2O3. Tese (doutorado) - Escola de Engenharia de São Carlos, USP, São Carlos, 1998, 153p.

SKALAK, R.; FOX, C. F. Tissue Engineering, Proceedings for a Workshop held at Granlibakken, Lake Tahoe, California, February 26-29, 1988, Alan Liss, New York.

UGARTE, J. F. O.; SENA, L. A.; PEREZ, C. A. C.; et al. Influence of processing parameters on structural characteristics of porous calcium phosphate samples: a study using an experimental design method. Mat. Res., Jan./Mar. 2005, vol.8, no.1, pp.7176. ISSN 1516-1439.

VEHOF, J. W. M.; TAKITA H.; KUBOKI, Y.; SPAUWEN, P. H. M.; JANSEN J. A. Histological characterization of the early stages of bone morphogenetic protein-induced osteogenesis. Journal of Biomedical Materials Research, 15 May 2002, vol.61, pp.440-449.

WATARI, F.; YOKOYAMA, A.; OMORI, M.; HIRAI, T.; KONDO, H.; UO, M.; KAWASAKI, T. Biocompatibility of material and development to functionally graded implant for biomedical application. Japan.Composite Science and Technology, 2004, pp. 893-908.

WATARI, F.; YOKOYAMA, A.; SASO, F.; UO, M.; KAWASAKI, T. Fabrication and properties of functionally graded dental implant. School of Dentistry, Hokkaido University, Sapporo 060, Japan. 1996, 7p.

WILLIAMS, D. F. Progress in biomaterial engineering: Definition in Biomaterials. Amsterdam: Elsevier, 1987, vol. 4. 
YANG, B. S. et al. Preparetion of bioactive nanotitania ceramics with biomechanical biocompatibility. Journal of Biomedical Materials Research, 2006, pp. 210-215.

YANG, S. et al. The Design of Scaffolds for Use in Tissue Engineering. Part I. Traditional Factors. Tissue engineering. 2001, vol.7, n-6, pp. 679-689.

ZANOTTO, E. D.; MIGLIORE, A. R. JR, Propriedades mecânicas dos materiais cerâmicos: Uma introdução. CERÂMICA, 1991, vol.37, n.247, pp.7-16.

ZAVAGLIA, C.A. de C. Aplicações de biocerâmica em próteses ortopédicas. Tese de Livre docência. UNICAMP. 1993.

ZAVAGLIA, C. A. Curso de Introdução à Cerâmicas. Apostila de biocerâmicas Faculdade de Engenharia Mecânica, Unicamp, Campinas. 2003. 